
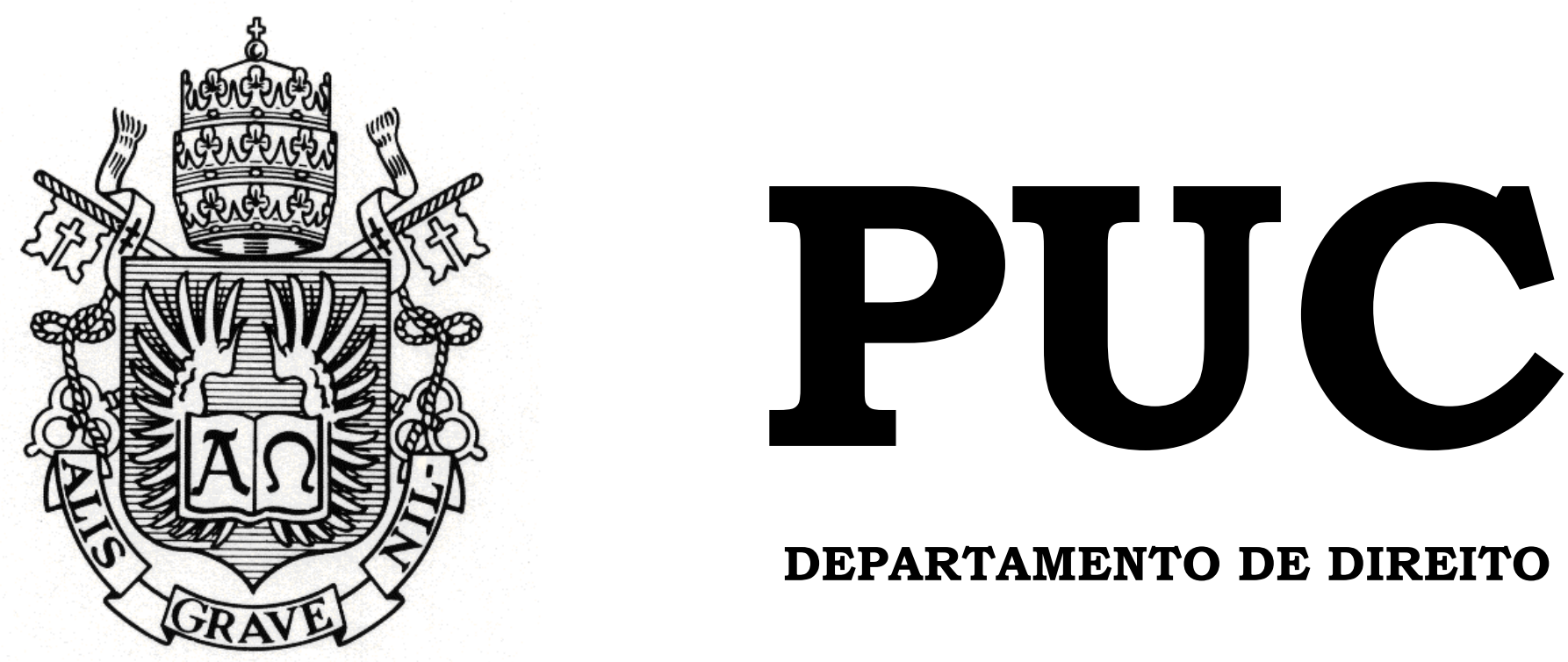

DEPARTAMENTO DE DIREITO

O afeto como valor juridico: uma análise sobre a legalidade da adoção intuitu personae.

por

Eleonora Santos Guerra

ORIENTADOR: Inês Alegria Rocumback

2013.2

PONTIFÍCIA UNIVERSIDADE CATÓLICA DO RIO DE JANEIRO

RUA MARQUÊS DE SÃO VICENTE, 225 - CEP 22453-900

RIO DE JANEIRO - BRASIL 


\title{
O afeto como valor juridico: uma análise sobre a legalidade da adoção intuitu personae.
}

\author{
por
}

\section{ELEONORA SANTOS GUERRA}

Monografia

apresentada

ao

Departamento de Direito da Pontifícia Universidade Católica do Rio de Janeiro (PUC-Rio) para a obtenção do Título de Bacharel em Direito.

Orientador: Inês Alegria Rocumback 
"Toda decisão que você toma, toda decisão não é uma decisão sobre o que você faz. É uma decisão sobre quem você é. Quando você vê isso, quando você entende isso, tudo muda. Você começa a ver a vida de um modo novo. Todos eventos, ocorrências e situações se transformam em oportunidades para fazer o que você veio fazer aqui".

Neale Donald Walsch 


\section{DEDICATÓRIA}

Dedico esta monografia a minha mãe, Rosângela, in memoriam, simplesmente mãe Rô, ser humano na acepção mais elevada e completa. Hoje me sinto advogada como você. Tenho um pouco da sua determinação e todo o seu exemplo de vida. Que um dia eu possa ser para os meus filhos a mãe dedicada e completa que você foi para mim. 


\section{AGRADECIMENTOS}

A Deus, aquele que está sempre no comando.

Aos meus pais José e Rosângela, os responsáveis pela minha vida, obrigada por tudo, tudo mesmo e, principalmente, pelo maior dos sentimentos, o amor. Certamente me faltam palavras para descrever tudo o que são e tudo que sempre fizeram por mim. Pai Jô, sem você esta caminhada não teria sido possível. Com você aprendi a ter os pés no chão, a planejar os passos e a acreditar que todo sacrifício é recompensado ao final. Muito obrigada por ser um pai completo, homem de grande caráter, trabalhador. Enfim, pai para toda obra. Mãe Rô, sempre vou lamentar a sua perda precoce, mas sei que você está sempre por perto. Seu legado é imensurável... Excelente mãe, excelente esposa, excelente amiga, excelente profissional, excelente com quem quer que seja, excelente em tudo. Você me ensinou a acreditar que a vida vale a pena, que é preciso vê-la com olhos positivos, aproveitá-la sempre e lutar com garra. Muito obrigada pelos 22 anos em que pude tê-la fisicamente presente. Muitas saudades.

A minha irmã, Érika, minha grande amiga. Obrigada por me ouvir sempre, até mesmo nos momentos mais difíceis, por ser a minha grande incentivadora. Sou um ser humano mais completo por ter o prazer de tê-la como irmã, mi hermana querida.

A minha família e a todos que de alguma forma contribuíram na minha caminhada.

Aos amigos da graduação em Jornalismo, especialmente Aline, Dani e Simone, que em muitos momentos ouviram minhas angústias e que sempre estiveram presentes.

Aos amigos do Direito, turma $2 \mathrm{HX}$, pelos 5 anos e meio de convivência, pela alegria sempre presente e pela juventude, ingredientes fundamentais para dar leveza à rotina nem sempre tão fácil. Carol, Camila, Dani, Mari, Vanessa, Sabrina, Breno, Gui, Ricardo, vocês têm lugar especial no meu coração. 
À professora Inês Alegria Rocumback, pelos ensinamentos nas disciplinas ECA (Estatuto da Criança e do Adolescente) e Direito de Família, que despertaram em mim, há alguns anos, a vontade de escrever o trabalho de conclusão de curso nesta área. Muito obrigada.

Aos demais professores de Direito da PUC-Rio, por todo o conteúdo ensinado e por lecionarem com brilhantismo e dedicação. Tenho orgulho de ser PUC-Rio 


\section{RESUMO}

O presente trabalho tem como tema a adoção intuitu personae. Serão apresentados os aspectos gerais da adoção, analisando a regra de observância do cadastro presente no Estatuto da Criança e do Adolescente, bem como a possibilidade de flexibilização da mesma, por exemplo, nas situações de adoção intuitu personae, isto é, modalidade de adoção na qual os genitores escolhem aqueles que serão os adotantes de seu(s) filho(s). Em nome do melhor interesse da criança e do adolescente, e da consolidada doutrina da proteção integral, presentes laços de afeto, o que se faz no exame das peculiaridades de cada um dos casos concretos, indubitável que se reconheça a legalidade desta peculiar forma de adoção.

\section{PALAVRAS-CHAVE}

Estatuto da Criança e do Adolescente. Adoção. Intuitu personae. Cadastro. Flexibilização. Afeto. Melhor interesse da Criança e do Adolescente. 


\section{SUMÁRIO}

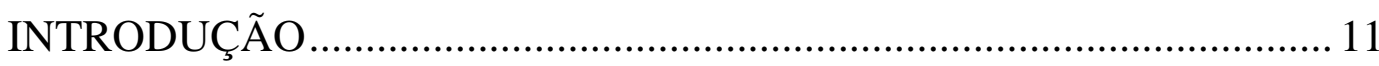

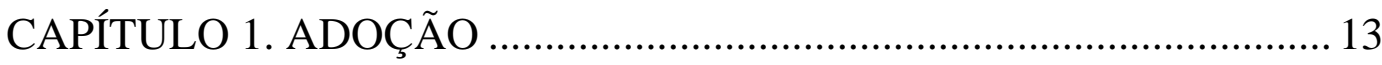

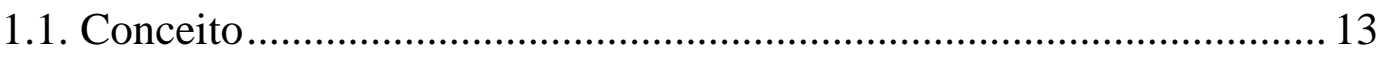

1.2. A adoção na Constituição de 1988 e no Código Civil de 1916............. 14

1.3. A adoção no Estatuto da Criança e do Adolescente (Lei 8.069/1990) e no Código Civil de 2002 (Lei 10.406/2002) ................................................. 16

1.4. A adoção na Lei Nacional de Adoção (Lei 12.010/2009) ..................... 21

1.5. As formas de colocação em família substituta: guarda, tutela e adoção

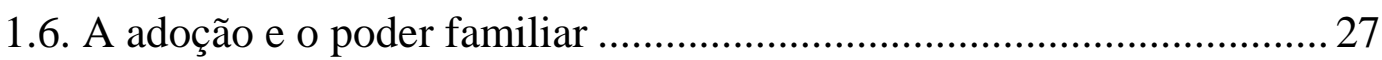

1.7. A adoção e o estágio de convivência...................................................... 29

1.8. Quadro comparativo das legislações ..................................................... 31

CAPÍTULO 2. OS CADASTROS DE ADOÇÃO ESTADUAIS E

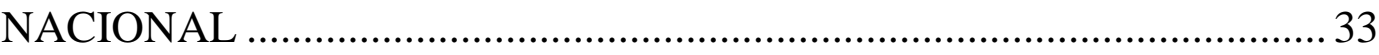

2.1. Os cadastros regionais previstos no Estatuto da Criança e do

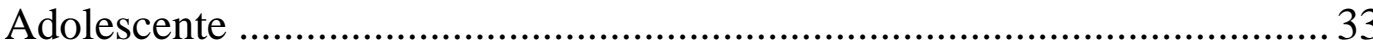

2.2. O Cadastro Nacional de Adoção (CNA) e o Cadastro Nacional de Crianças e Adolescentes Acolhidos (CNCA) implantados pelo Conselho

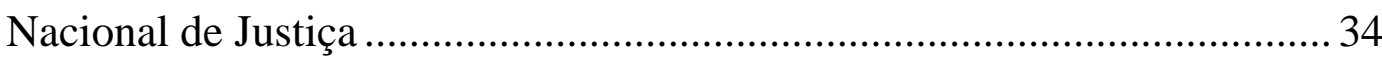

2.3. A necessidade de habilitação como condição prévia à inscrição no cadastro de adotantes e a sua possível flexibilização ...................................... 41

CAPÍTULO 3. ADOÇÃO INTUITU PERSONAE ...................................... 52

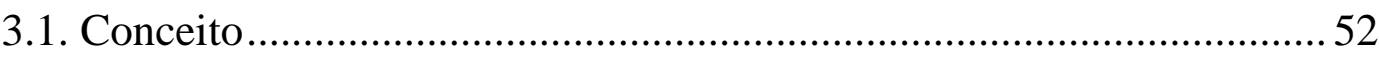

3.2. Adoção intuitu personae e adoção à brasileira ......................................... 55

3.3. Da divergência na doutrina quanto à legalidade da adoção intuitu

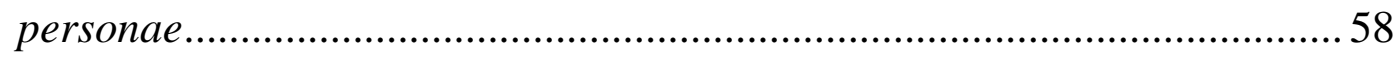


3.3.1. O poder familiar e o elemento escolha na adoção dirigida: 60

3.3.2. O atendimento ao estágio de convivência na adoção intuitu personae 62

3.3.3. A possibilidade do deferimento da adoção sem atender ao cadastro 63 3.4. O Projeto de Lei $n^{\circ}$ 1212/2011: adoção consentida pode virar lei....... 66

CAPÍTULO 4. A adoção intuitu personae na jurisprudência ..................... 69

4.1. Recurso Especial 1172067/MG ....................................................69

4.1.1. Análise do relatório ..................................................................... 71

4.1.2. Análise do voto do Relator: ......................................................... 73

4.2. Recurso Especial n ${ }^{\circ} 1.262 .996$ - RN ............................................. 75

4.3. Agravo em Recurso Especial no 256.238 - RN ............................... 77

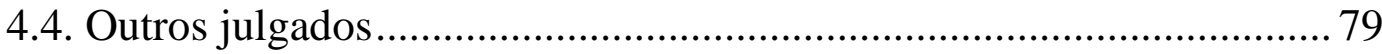

4.4.1. TJRJ - Apelação ${ }^{\circ}$ 0006371-74.2009.8.19.0061 ............................ 80

4.4.2. TJRJ - Agravo de Instrumento ${ }^{\circ}$ 0026403-89.2009.8.19.0000 .......81

4.4.3. TJRS - Apelação Cível $n^{\circ} 70015551138$..................................... 81

4.4.4. TJSP - Apelação Cível $n^{\circ} 116.199-0 / 8-00$..................................... 82

CONCLUSÃO

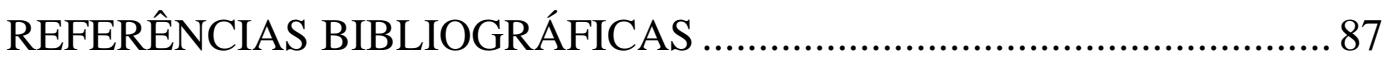

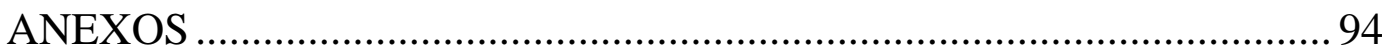




\section{Crônica de um bebezinho escolhendo sua mãe e seu pai ${ }^{1}$}

Um bebezinho prematuro foi entregue por sua mãe biológica para adoção. O bebezinho nasceu antes da mãe completar os nove meses de gestação e precisou de alguns cuidados especiais no hospital público onde nasceu. Assim que recebeu alta foi levado para a Vara da Infância e Juventude do Rio de Janeiro. A mãe declarou que não tinha condição de criar o filho e gostaria de dar em adoção.

A Juíza determinou fosse chamado o primeiro casal da lista do Cadastro Único. Esta lista é composta de pessoas habilitadas para adoção. A habilitação é um procedimento onde as pessoas interessadas são ouvidas em seus interesses e recebem orientação de assistentes sociais e psicólogas sobre o caminho da adoção, suas consequências e são avaliados. Habilitados pelo Juízo, podem receber uma criança em adoção.

$\mathrm{O}$ bebezinho, que chegou ao mundo há pouco, foi entregue ao primeiro casal da lista. Logo depois foi trazido de volta à Vara da Infância e Juventude. Não houve adaptação. A Juíza chamou o segundo casal da lista do Cadastro Único. O casal levou o bebezinho, e como se faz com o filho que acaba de chegar, levaram-no ao médico, fizeram exames e receberam um laudo de que o bebezinho tinha problemas graves na retina. Um dos olhos com sério comprometimento e o outro em situação grave. Havia recomendação de tratamento médico imediato e até cirurgia oftalmológica. $\mathrm{O}$ casal entendeu que deveria entregar a criança na Vara da Infância e Juventude.

Pela terceira vez o bebezinho, com dias de vida, comparece à Vara. Mas desta vez algo teria que ser diferente. Como um bebezinho tão lindo e adorável poderia retornar perante uma Juíza pela terceira vez e não para uma Mãe e um Pai que o acolhessem como ele era, um lindo bebê? O

\footnotetext{
$\overline{1} \quad$ Extraído do blog http://direitosdasfamilias.blogspot.com.br/search?q=Cr\%C3\%B4nica+de+um+bebezinho+escolhe ndo+sua + m\%C3\%A3e+e+seu+pai
} 
problema de saúde que apresentava não tirava dele a condição de um bebê recém nascido. O que se faz quando um filho biológico nasce com problemas de visão? Confere-se o tratamento médico, cuida-se com todo amor e carinho. Era isso que o bebezinho precisava. Amor, tratamento, carinho, cuidado.

"Chega de ir visitar a Juíza! Agora é hora de ficar com a Mamãe". Curiosamente uma pequena nota no jornal, na coluna do Anselmo Goes, do jornal O Globo, causou uma mobilização intensa. No mesmo dia da notícia no jornal, diversas pessoas de várias profissões procuraram a Juíza para oferecer ajuda, para realizar a cirurgia sem nada cobrar, para cuidar e dar o que aquele bebezinho deveria receber.

Finalmente, o Cadastro Único passou a ser o da criança. Na fila de espera não estava mais o bebezinho, oferecido para quem poderia ou não aceitá-lo. O bebezinho passou a escolher não pela ordem dos adultos, mas pela ordem do coração. Quem o amava incondicionalmente sem sequer o ter visto? Quem queria cuidá-lo sem pensar que era um boneco com defeito de fabricação? Quem não o devolveria como se fosse um brinquedo para uma loja? Finalmente, seus pais chegaram. Vieram buscá-lo. Vão cuidar dele. Amá-lo. Dar o tratamento médico para que possa enxergar este mundo e ver que o ser humano tem muito valor e que vale acreditar que é possível ser feliz e que o ser humano merece credibilidade. A Juíza dormirá hoje com o coração um pouquinho mais aliviado sem esquecer que amanhã tem mais. 


\section{INTRODUÇÃO}

Adoção intuitu personae é o tema desta monografia. Trata-se de modalidade de adoção na qual os genitores escolhem a quem entregar seu filho. No Brasil, país em que ainda persiste grande parte da população abaixo da linha de pobreza, é comum que crianças venham ao mundo e que seus pais não tenham condições de criá-las. Como solução, entregam o seu respectivo filho diretamente a quem acham preparados para tal. Ou, então, também dão o rebento por tantos outros infinitos motivos, até mesmo escusos. A adoção é tema sempre recorrente no mundo jurídico e até mesmo fora dele. Trata-se de um instituto delicado, que envolve aspectos não abordados pela letra, por tantas vezes, fria da lei.

$\mathrm{O}$ presente trabalho tem como título "O afeto como valor jurídico: uma análise sobre a legalidade da adoção intuitu personae”. Assim sendo, pretenderemos discorrer sobre esta peculiar forma de adoção, também chamada de dirigida ou consentida, entendendo que ela é plenamente legal e possível, quer porque nossa legislação que cuida do tema, a saber, o Estatuto da Criança e do Adolescente (ECA), com as alterações incluídas pela Lei 12.010/2009, não a vedou, quer porque o mesmo ECA, por outro lado, permitiu que se abrisse mão de respeitar o mandamento contido no caput do seu artigo 50, qual seja, do respeito à fila do cadastro, em detrimento da formação de vínculos de afeto e afetividade. $\mathrm{O}$ afeto surge como justificativa ao deferimento de pedidos que envolvam a adoção intuitu personae.

Assim sendo, no primeiro capítulo, "Adoção", traremos uma análise sobre o conceito de adoção, bem como a evolução histórica deste instituto ao longo de nossas legislações, começando pelo Código Civil de 1916, passando pelas significativas mudanças introduzidas pela Constituição da República Federativa do Brasil de 1988, que culminaram com a edição da Lei 8.069/1990, o Estatuto da Criança e do Adolescente, e suas posteriores modificações e inclusões pela Lei 12.010/2009, a Lei de Adoção. Em linhas 
gerais, abordaremos, também, a tutela e a guarda, ou seja, as outras duas formas de colocação em família substituta. Ademais, ao falarmos em adoção, torna-se necessário analisar o poder familiar e o estágio de convivência.

Em um segundo momento deste trabalho, averiguaremos as previsões de cadastro de adoção presentes no nosso ordenamento, começando pelos primeiros, os cadastros regionais previstos no ECA, passando ao Cadastro Nacional de Adoção (CNA) e Cadastro Nacional de Crianças e Adolescentes Acolhidos (CNAC), ambos criados por Resoluções do $\mathrm{CNJ}$, a saber, respectivamente, $\mathrm{n}^{\circ} 54$ e $\mathrm{n}^{\circ}$ 93. Ao falarmos de cadastro, a análise da habilitação a este se faz útil e essencial. Sendo a habilitação etapa anterior à inscrição no cadastro, ou seja, condição prévia para tal, merece reflexão a tese acerca da possibilidade de sua flexibilização em nome do mandamento constitucional do melhor interesse da criança e do adolescente e da doutrina da proteção integral dos mesmos enquanto sujeitos de diretos em formação.

No capítulo 3, "Adoção Intutiu Personae", enfrentaremos o exame desta peculiar modalidade de adoção, que tanto gera debates e que tanto divide opiniões na doutrina quanto a sua legalidade. Para isso, traremos os entendimentos de estudiosos do Direito e debateremos as implicações deste tipo de adoção no poder familiar e no estágio de convivência exigido pelo Estatuto.

Por fim, fundamental investigar alguns julgados, sendo emblemático o Recurso Especial 1172067/MG, por vezes citado em outras decisões envolvendo o tema. Qualquer análise que se faça precisa passar pelo caso concreto. Somente dessa forma, individualizada e peculiar, é que o julgador poderá aferir o que, de fato e precipuamente, atende ao melhor interesse da criança e do adolescente, centros de interesse envolvendo adoção. 


\section{CAPÍTULO 1. ADOÇÃO}

\subsection{Conceito}

A palavra adoção origina-se do latim adoptio, tendo surgido por um princípio religioso de perpetuação do culto familiar. No dizer de Caio Mário,

basta-nos uma visada sobre a sua configuração romana, que fundamenta o desenvolvimento do instituto em nosso direito, muito embora haja desaparecido aquela inspiração religiosa, substituída pela necessidade de satisfazer o instinto paternal, ou de cumprir as exigências do sentimento de solidariedade humana ${ }^{2}$.

Do Direito Romano, podemos encontrar o seguinte conceito para adoção: "ato solene pelo qual se admite em lugar de filho quem pela natureza não é"3. É verdade que a conceituação de adoção varia de acordo com a época e com as tradições. Em nosso país, inúmeros juristas trataram de defini-la: "Adoção é acto pelo qual alguém acceita um estranho na qualidade de filho." ; "Adoção é ato solene pelo qual se cria entre o adotante e o adotado relação fictícia de paternidade e filiação. ",5

Adoção vem a ser o ato jurídico solene pelo qual, observados os requisitos legais, alguém estabelece, independentemente de qualquer relação de parentesco consanguíneo ou afim, um vínculo fictício de filiação, trazendo para sua família na condição de filho, pessoa que, geralmente, lhe é estranha. ${ }^{6}$

Adoção é ato sinalagmático e solene, pelo qual, obedecidos os requisitos fixados em lei, alguém estabelece, geralmente com um estranho, um vínculo fictício de paternidade e filiação legítimas, de efeitos limitados e sem total desligamento do adotando da sua família de sangue. ${ }^{7}$

${ }^{2}$ PEREIRA, Caio Mário da Silva. Instituições de direito civil. Vol. V. Direito de Família, 2009. p. 405.

${ }^{3}$ RODRIGUES, Dirceu A. Victor. Dicionário de Brocardos Jurídicos. São Paulo: Ed. Ateniense, 1995. p.22.

${ }^{4}$ BEVILACQUA, Clóvis. Código Civil dos Estados Unidos do Brasil Comentado. v.II, Livraria Francisco Alves, 1943. p. 346.

${ }^{5}$ PONTES DE MIRANDA. Tratado de Direito Privado. v.9, Ed. Borsoi, 1951. p.21.

${ }^{6}$ DINIZ, Maria Helena. Curso de Direito Civil Brasileiro. Direito de Família. Ed. Saraiva, v.5, 1995, p. 282.

${ }^{7}$ CHAVES, Antonio. Adoção e Legitimação adotiva. Ed. Rev. Dos Tribunais, 1966. pp. 17-18. 
As definições supracitadas são adequadas à concepção de adoção do Código Civil de 1916 e às leis posteriores que regularam o tema. A sistemática se modifica radicalmente com a nossa Constituição Federal de 1988 e com a posterior edição do Estatuto da Criança e do Adolescente, marcos que trataremos a seguir. Passamos a uma breve análise da evolução histórica do instituto da adoção no Código Civil de 1916, na Constituição Federal de 1988, no Estatuto da Criança e do Adolescente de 1990 e, por último, na Lei de Adoção de 2009.

\subsection{A adoção na Constituição de 1988 e no Código Civil de 1916}

Com a promulgação da Constituição da República Federativa do Brasil de 1988, a tradição jurídica brasileira evoluiu, passando a incluir o que fora anteriormente pactuado pela Declaração Universal dos Direitos do Homem desde 1948. Em outras palavras, foi dado um passo rumo à concepção da valorização da pessoa humana como sendo razão fundamental para a estruturação da organização do Estado e do Direito. O ser humano se edifica no centro de todo o ordenamento jurídico, no sentido de que as normas são feitas para a pessoa e para a sua realização existencial. Neste diapasão, o Estado passa a ter o dever de respeitar, proteger e promover as condições que viabilizem a vida com dignidade. E a família neste contexto é instrumento na realização de interesses afetivos e existenciais de seus componentes. Embora a palavra "afeto" não apareça no texto constitucional, este sentimento é, contemporaneamente, considerado pelos juristas como o principal fundamento das relações familiares, o que se traduz no chamado sentimento de família, família esta com novos contornos, o que desafia a possibilidade de se encontrar um conceito único para ela.

O Estado impõe a si obrigações para com os seus cidadãos. Por isso elenca a Constituição um rol imenso de direitos individuais e sociais, como forma de garantir a dignidade de todos. Isso nada mais é do que o compromisso de assegurar afeto. [...] Com a consagração do afeto a direito fundamental, resta 
enfraquecida a resistência dos juristas que não admitem a igualdade entre filiação biológica e a socioafetiva. O princípio jurídico da afetividade faz despontar a igualdade entre irmãos biológicos e adotivos e o respeito a seus direitos fundamentais. O sentimento de solidariedade recíproca não pode ser perturbado pela preponderância de interesses patrimoniais ${ }^{8}$.

Sendo assim, nossa Constituição de 1988 igualou os direitos de todos os filhos. No seu Título VIII, Capítulo, VII, Da Família, da Criança, do Adolescente e do Idoso, estabeleceu no $\S 6^{\circ}$ do artigo 227: “Os filhos, havidos ou não da relação do casamento, ou por adoção, terão os mesmos direitos e qualificações, proibidas quaisquer designações discriminatórias relativas à filiação". A designação "fillho ilegítimo" foi definitivamente banida de nosso ordenamento e a Constituição, ao fazer referência expressa ao filho adotivo, eliminou qualquer controvérsia que ainda pudesse persistir. A finalidade da moderna adoção é acolher a criança ou o adolescente num ambiente familiar, inserindo o adotado neste ambiente, como parte integrante do mesmo.

A adoção, como hoje é entendida, não consiste em "ter pena" de uma criança, ou resolver situação de casais em conflito, ou remédio para a esterilidade, ou, ainda, conforto para a solidão. $\mathrm{O}$ que se pretende com a adoção é atender às reais necessidades da criança, dando-lhe uma família, onde ela se sinta acolhida, protegida, segura e amada. É bom que se reflita que existe um processo, um desafio permanente e necessidade de constante reflexão sobre o tema ${ }^{9}$.

Por orientação de documentos internacionais de proteção à infância, como, por exemplo, a Convenção dos Direitos da Criança, que se tornou lei interna através do Decreto Lei 99710/90, deve predominar o princípio do "melhor interesse da criança" como norteador da adoção. Em face da conhecida doutrina jurídica da proteção integral, deve sempre prevalecer o reconhecimento constitucional da criança e do adolescente como titulares de Direitos Fundamentais e como pessoas em condição peculiar de desenvolvimento.

No Código Civil de 1916, a adoção estava disciplinada nos artigos 368 a 378, sendo um ato bilateral e solene, com indispensável manifestação

\footnotetext{
${ }_{8}^{8}$ DIAS, Maria Berenice. Manual de Direito das Famílias. p. 70.

${ }^{9}$ GRANATO, Eunice. Adoção doutrina e prática. Ed. Juruá. 2009. p.26.
} 
da vontade do adotante e do adotando e com imprescindível forma notarial. De certo, nosso antigo Código Civil trazia obstáculos legais à integração total do adotado à família do adotante. Por exemplo, só os maiores de 30 anos podiam adotar; as pessoas casadas só poderiam adotar após completarem cinco anos de casamento; o adotante deveria ser pelo menos dezesseis anos mais velho que o adotado; pela sua natureza de contrato, permitia a resilição da adoção por mútuo acordo ou unilateralmente; o Ministério Público só era chamado a se manifestar quando da averbação da adoção no registro de nascimento por expressa previsão da Lei de Registros Públicos, Lei 6.015/73; o adotado só herdaria do adotante se este não tivesse filhos. Caso o filho adotivo concorresse com filhos legítimos supervenientes à adoção, o filho adotivo somente receberia metade da herança cabível a cada um dos legítimos. Enfim, as distinções entre filhos biológicos e adotivos eram flagrantes.

Dessa forma, o Código Civil de 1916 deu vida a uma relação jurídica de parentesco meramente civil entre adotado e adotante, com a finalidade de proporcionar filiação a quem não tivesse por vínculos de sangue, contexto amplamente modificado pela Constituição Federal de 1988, que fez a pessoa humana evoluir significativamente nas relações familiares, edificando quatro fundamentos essenciais baseados na afetividade: a igualdade de todos os filhos independentemente da origem (artigo 227, $\S 6^{\circ}$ ); a adoção como escolha afetiva com igualdade de direitos (artigo 227, $\S \S 5^{\circ}$ e $6^{\circ}$ ); a comunidade formada por qualquer dos pais e seus descendentes, incluindo os adotivos, com a mesma dignidade da família

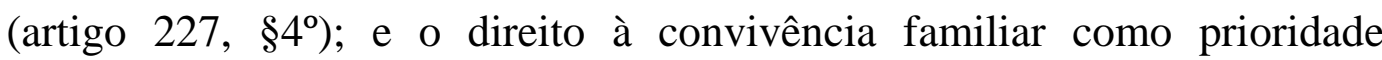
absoluta da criança, do adolescente e do jovem (artigo 227).

\subsection{A adoção no Estatuto da Criança e do Adolescente (Lei 8.069/1990) e no Código Civil de 2002 (Lei 10.406/2002)}


Na esteira da Constituição brasileira de 1988, o Estatuto da Criança e do Adolescente, Lei 8.069 , de 13 de julho de $1990^{10}$, tornou possível a plena efetivação de todos os direitos fundamentais assegurados à criança e ao adolescente no artigo 227 da nossa Carta Maior. Nesse aspecto, oportuno transcrever a conjuntura definida por Murillo José Digiácomo, Promotor de Justiça no Estado do Paraná:

Há mais de 20 anos, o ordenamento jurídico brasileiro sofreu uma verdadeira revolução na forma como crianças e adolescentes (até então chamados genericamente de "menores") eram vistos, compreendidos e tratados. Com o advento da Constituição Federal de 1988 e da Convenção das Nações Unidas sobre os Direitos da Criança e do Adolescente de 1989, crianças e adolescentes deixaram a condição de meros "objetos" de intervenção estatal para se tornarem sujeitos de direitos e destinatários da proteção integral e prioritário por parte da família, da sociedade e do Estado (lato sensu), tornando imprescindível a edição de novos marcos normativos infraconstitucionais. ${ }^{11}$.

Neste contexto histórico surgiu o Estatuto da Criança e do Adolescente, ECA, verdadeiro marco na efetivação de direitos constitucionalmente estabelecidos. Fala-se em efetivação destes direitos porque não foi o ECA que os introduziu. A inserção destes direitos se deu pela Constituição Federal de 1988, mas foi o Estatuto quem forneceu instrumentos necessários à plena efetivação de todos os direitos fundamentais assegurados à criança e ao adolescente. Por exemplo, em relação à adoção, tratada especificamente nos artigos 39 a 52-A do ECA, profundas modificações foram introduzidas, sendo certo que o espírito do legislador é o da proteção integral da criança e do adolescente, conforme assim preceitua o seu artigo $1^{\text {o: }}$ "esta lei dispõe sobre a proteção integral à criança e ao adolescente”.

A inovação marcante desta lei foi colocar todos os menores de 18 anos e não apenas aqueles que estivessem em situação irregular, como ocorria na lei anterior, o Código de Menores, Lei 6.697/1979, na situação

\footnotetext{
10 Disponível em: http://www.planalto.gov.br/ccivil_03/ato2007-2010/2009/lei/112010.htm. Acesso em 17/08/2013.

11 DIGIÁCOMO, Murillo José. Da impossibilidade jurídica da adoção intuitu personae no ordenamento jurídico brasileiro à luz da lei no. 12.010/2009 e da Constituição Federal de 1988. Disponível em: http://www.crianca.mppr.mp.br/modules/conteudo/conteudo.php?conteudo=1081. Acesso em 21/08/2013.
} 
de adotandos. Tanto é que o artigo $2^{\circ} \log$ define criança e adolescente: "considera-se criança, para os efeitos desta Lei, a pessoa até doze anos de idade incompletos $e$, adolescente, aquela entre doze e dezoito anos de idade". Ademais, no parágrafo único deste mesmo dispositivo há a informação segundo a qual "nos casos expressos em lei, o Estatuto da Criança e do Adolescente será aplicado, excepcionalmente, às pessoas entre dezoito e vinte e um anos de idade".

O ideal do legislador constitucional foi repetido no Estatuto, que visivelmente optou pela finalidade de dar uma família para os desamparados. E mais: proporcionar a integração do adotando na família do adotante, em tudo igualando o filho adotivo ao filho natural ${ }^{12}$. É o que se depreende da leitura do disposto no artigo 28, que afirma ser a adoção, ao lado da tutela e da guarda, modalidade de colocação do menor de dezoito anos em família substituta, conceito trazido pelo artigo 25 e que compreende, em oposição à família natural, a "comunidade formada pelos pais ou qualquer deles e seus descendentes". É aquela família formada pelo indivíduo ou somatório de indivíduos que exercerá, perante a criança ou adolescente, os deveres e direitos inerentes à guarda ou ao poder familiar, com formação ou não de vínculos de parentesco de $1^{\circ}$ grau. Estabelece o artigo 30 do ECA que, "a colocação em familia substituta não admitirá transferência da criança ou do adolescente a terceiros ou a entidades governamentais, sem autorização judicial”. Tal dispositivo encaixa-se no momento anterior à colocação da criança ou do adolescente em família substituta e é expresso sobre a subordinação ao império da lei, de forma a manter o direito fundamental à convivência familiar, preceito constitucional estabelecido pelo artigo 227, $\S 5^{\circ}$ da Carta Maior: "a adoção será assistida pelo Poder Judiciário, na forma da lei, que estabelecerá casos e condições

\footnotetext{
12 A nova ordem legal', a teor do que expressa o $\S 6^{\circ}$ do artigo 227 da Constituição da República Federativa do Brasil de 1988, proibiu quaisquer designações discriminatórias à filiação. Dessa forma, os mesmos direitos passaram a ser assegurados aos filhos nascidos ou não da relação de casamento, bem como aos filhos havidos por adoção. Dessa forma, não se faz mais a distinção entre filho adotivo e filho natural.
} 
de sua efetivação por parte de estrangeiros". Dessa forma, o rompimento do vínculo original do poder familiar, família natural, necessariamente tem que passar pelo crivo judicial.

Nesta linha, é condição para o deferimento da adoção a garantia de que ela apresentará reais vantagens para o adotando, ou seja, que ela é realizada no seu melhor interesse. Assim sendo, vigora no sistema do Estatuto a primazia do interesse do adotado, finalidade da adoção, interesse este que irá determinar o deferimento ou não do pedido de adoção.

Com a entrada em vigor do Código Civil de 2002, Lei 10.406, em 11 de janeiro de 2003, a adoção passou a ser tratada nos artigos 1.618 a 1.629, sendo que os artigos 1.620 a 1.629 foram revogados pela Lei 12.010/2009, a Lei Nacional de Adoção. O artigo 1.618 traz que a adoção será deferida na forma prevista pelo Estatuto da Criança e do Adolescente, limitando-se a falar que a adoção de maiores de 18 anos dependerá de assistência efetiva do poder público, em oposição ao Código Civil de 1916, que determinava que a adoção de maiores fosse feita diretamente em Cartório, e de sentença constitutiva com aplicação das regras gerais do Estatuto, no que couber. Sobre o procedimento de adoção previsto no ECA, trataremos do tema no capítulo 2 .

Nos dizeres a seguir, respectivamente, de João Seabra Diniz e Sergio Gischkow Pereira, a adoção do ECA tem maior abrangência, indicadora da finalidade voltada para os interesses do adotando:

podemos definir a adoção como inserção num ambiente familiar, de forma definitiva e com aquisição de vínculo jurídico próprio da filiação, segundo as normas em vigor, de uma criança cujos pais morreram ou são desconhecidos, ou, não sendo esse o caso, não podem ou não querem assumir o desempenho das suas funções parentais, ou são pela autoridade competente, considerados indignos para $\operatorname{tal}^{13}$.

a adoção é instituto por demais sublime e grandioso para amesquinhar com exegeses restritivas alicerçadas no fechamento egoístico da família consangüínea, em estranhas concepções sobre meias filiações e no aceitar de uma desigualdade

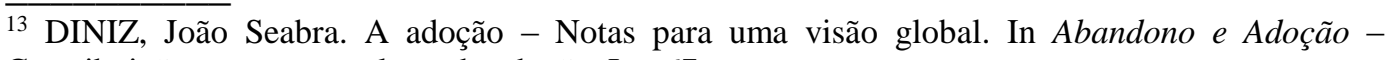
Contribuições para uma cultura da adoção. I. p.67. 
que só provocará traumas psíquicos ao adotado, tudo em nome de interesses menores, porque puramente patrimoniais, ou seja, vinculados à herança. ${ }^{14}$

Todas estas alterações deixam clara a preocupação do legislador com a efetivação de um controle judicial rigoroso em relação à adoção. Tanto é que a competência para tratar de adoção é exclusiva da Justiça Especializada, ou seja, da Justiça da Infância e da Juventude, consoante disposto nos artigos 39 e 148, inciso III, da Lei 8.069/90.

Ao lado, há que se destacar a existência de uma complexa estrutura de atendimento, com equipe interdisciplinar, fundamentais à aferição da real situação de adotante(s) e adotando(s).

O operador da fração do direito que atende a infância e a juventude não tem a permissão para seguir o caminho empírico. Sua ação, manifestação ou decisão deve estar alicerçada no conhecimento técnico fornecido pelas áreas interagentes, pois, mais que a forma jurídica, o que importa é o maio interesse do indivíduo passível de adoção, e esse é apurado com o auxílio das áreas médicas e sociais. ${ }^{15}$

No campo do direito de família, a inclusão de especialistas nas intervenções, principalmente os psicólogos jurídicos, institui um caráter mais humanizado ao processo. Surge a necessidade de reformar o olhar dirigido ao sujeito e à família. Urge incluir o afeto como referencial jurídico e a leitura do sujeito precisa ser a leitura deste enquanto sujeito de desejo, aspecto fundamentalmente ligado à adoção intuitu personae. Além disso, sempre que possível, o juiz ouvirá a criança ou o adolescente e tal oitiva é de importância fundamental para o convencimento do magistrado. Consoante o disposto no artigo $45, \S 2^{\circ}$ do ECA, "em se tratando de adotando maior de doze anos de idade, será também necessário o seu consentimento”, o adolescente deverá dar sua expressa concordância sobre a adoção.

(...) deve haver a concordância do adotando maior de 12 anos. Essa exigência está consubstanciada no $\S 2^{\circ}$ do art. 45 do Estatuto que, como já destacado, se utiliza da técnica legislativa ruim, pois refere a "adotando maior de doze anos de idade", quando o ideal seria que constasse a expressão "adotando com 12 anos

\footnotetext{
${ }^{14}$ PEREIRA, Sergio Gischkow. A adoção e o direito intertemporal. In: Revista dos Tribunais, v.686, p.169.

15 ALMEIDA, Julio Alfredo de. Adoção Intutitu Personae - uma proposta de agir. Síntese da Monografia de Especialização em Direito Comunitário: Infância e Juventude. Fundação Escola Superior do Ministério Público. Porto Alegre, 2002. p. 25.
} 
completos", ou sejam adotando adolescente. Ademais, a criança, quando possível, também será ouvida, ainda que sua opinião não seja determinante. Trata-se de decorrência do princípio da proteção integral, em que crianças e adolescentes são sujeitos de direitos, e não objeto de proteção. ${ }^{16}$

\subsection{A adoção na Lei Nacional de Adoção (Lei 12.010/2009)}

A Lei 12.010, de 03 de agosto de 2009 (ANEXO 1), a chamada "Lei Nacional de Adoção", promoveu inúmeras modificações no Estatuto da Criança e do Adolescente. Trata-se da incorporação de mecanismos que têm como objetivo, dentre outros, dar celeridade ao procedimento de adoção, reduzindo o tempo de permanência de crianças e adolescentes em instituições. Em linhas gerais, a Lei de Adoção deu nova redação a dois artigos do Código Civil de 2002 e revogou todos os outros que tratavam do assunto, deixando para o ECA a regulamentação do tema.

Neste diapasão, oportuno frisar que a idéia da Lei Nacional de Adoção foi tornar o controle mais rígido, "lapidando" o Estatuto da Criança e do Adolescente. Órgãos e autoridades públicas passaram a ter deveres de efetivação do exercício do direito à convivência familiar, do acolhimento de crianças e adolescentes em instituições - não mais chamadas de abrigos, palavra utilizada na época do hoje revogado Código de Menores -, e o dever de reavaliar a situação de cada um deles no intervalo de seis meses, na tentativa de recolocá-los nas suas famílias de origem, preferencialmente, ou em família substituta. Também trouxe a imposição de criação e manutenção de cadastros estaduais e nacional de adoção, de desenvolvimento de programas de orientação para aqueles que se interessam pela adoção. Enfim, medidas que pudessem resguardar o instituto da adoção, dentre outros, dado que o contexto da adoção é o da excepcionalidade porque o interesse primeiro é a permanência da criança ou do adolescente na sua família de origem. Sobre esta lei, Maria Berenice Dias e Murillo José Digiácomo, respectivamente, tecem algumas críticas, a saber que

\footnotetext{
${ }^{16}$ ROSSATO. Luciano Alves. São Paulo: Revista dos Tribunais, 2010.
} 
muitas mudanças são mera troca de palavras [...] Claro que a lei tem méritos. [...] O fato é que a adoção transformou-se em medida excepcional, à qual se deve recorrer apenas quando esgotados os recursos de manutenção da criança e do adolescente na família natural ou extensa. Assim, a chamada Lei de Adoção não consegue alcançar os seus propósitos. Em vez de agilizar a adoção, acaba por impor mais entraves para sua concessão. ${ }^{17}$

o propósito da Lei 12.010/2009, portanto, não poderia ser mais explícito, e as inovações legislativas por ela introduzidas no texto da Lei 8.069/1990, analisadas tanto de maneira individual quanto em seu contexto, sem dúvida, foram instituídas com o propósito de erradicar, agora em definitivo, as referidas práticas contra legem, que como dito, não mais podem subsistir no mundo jurídico. ${ }^{18}$

As práticas contra legem supra referidas pelo Promotor de Justiça Murillo José Digiácomo compreendem, por exemplo, a escolha aleatória e arbitrária de pessoas para adotarem crianças e adolescentes, escolha esta que não se alinha com a adoção intuitu personae que aqui pretenderemos defender, ou seja, aquela deferida após uma análise cautelosa e criteriosa de todos os parâmetros normativos aplicáveis e sempre atendendo, de fato, aos interesses dos adotandos.

A redação original do ECA e toda a sua sistemática já deixavam claro que a Justiça da Infância e da Juventude não poderia continuar a agir como fazia a Justiça sob a égide do Código de Menores, de 1979, ou seja, não lhe cabia mais pura e simplesmente homologar atos de mera disposição do poder familiar nos quais crianças e adolescentes eram tratados como objetos e, não, como sujeitos de direitos. No entanto, o ECA, e antes dele o artigo 227 da Constituição Federal de 1988 e a Convenção da ONU sobre os Direitos da Criança, de 1989, não foram suficientes para provocar uma mudança na concepção e na prática de muitos dos nossos operadores do Direito. Assim, a Lei de Adoção introduziu uma série de princípios que devem nortear a aplicação das medidas protetivas, expressos no parágrafo único do artigo 100 do ECA, de oportuna transcrição:

\footnotetext{
17 DIAS, Maria Berenice. Manual de Direito das Famílias. $7^{\mathrm{a}}$ ed.. São Paulo: Ed. Revista dos Tribunais, 2011. pp. 477-478.

18 DIGIÁCOMO, Murillo José. Da impossibilidade jurídica da adoção intuitu personae no ordenamento jurídico brasileiro à luz da lei no. 12.010/2009 e da Constituição Federal de 1988. Disponível em: http://www.crianca.mppr.mp.br/modules/conteudo/conteudo.php?conteudo=1081. Acesso em 21/08/2013.
} 
São também princípios que regem a aplicação das medidas:I - condição da criança e do adolescente como sujeitos de direitos: crianças e adolescentes são os titulares dos direitos previstos nesta e em outras Leis, bem como na Constituição Federal; II - proteção integral e prioritária: a interpretação e aplicação de toda e qualquer norma contida nesta Lei deve ser voltada à proteção integral e prioritária dos direitos de que crianças e adolescentes são titulares; III - responsabilidade primária e solidária do poder público: a plena efetivação dos direitos assegurados a crianças e a adolescentes por esta Lei e pela Constituição Federal, salvo nos casos por esta expressamente ressalvados, é de responsabilidade primária e solidária das 3 (três) esferas de governo, sem prejuízo da municipalização do atendimento e da possibilidade da execução de programas por entidades não governamentais; IV - interesse superior da criança e do adolescente: a intervenção deve atender prioritariamente aos interesses e direitos da criança e do adolescente, sem prejuízo da consideração que for devida a outros interesses legítimos no âmbito da pluralidade dos interesses presentes no caso concreto; V privacidade: a promoção dos direitos e proteção da criança e do adolescente deve ser efetuada no respeito pela intimidade, direito à imagem e reserva da sua vida privada; VI - intervenção precoce: a intervenção das autoridades competentes deve ser efetuada logo que a situação de perigo seja conhecida; VII - intervenção mínima: a intervenção deve ser exercida exclusivamente pelas autoridades e instituições cuja ação seja indispensável à efetiva promoção dos direitos e à proteção da criança e do adolescente; VIII - proporcionalidade e atualidade: a intervenção deve ser a necessária e adequada à situação de perigo em que a criança ou o adolescente se encontram no momento em que a decisão é tomada; IX - responsabilidade parental: a intervenção deve ser efetuada de modo que os pais assumam os seus deveres para com a criança e o adolescente; X prevalência da família: na promoção de direitos e na proteção da criança e do adolescente deve ser dada prevalência às medidas que os mantenham ou reintegrem na sua família natural ou extensa ou, se isto não for possível, que promovam a sua integração em família substituta; XI - obrigatoriedade da informação: a criança e o adolescente, respeitado seu estágio de desenvolvimento e capacidade de compreensão, seus pais ou responsável devem ser informados dos seus direitos, dos motivos que determinaram a intervenção e da forma como esta se processa; XII - oitiva obrigatória e participação: a criança e o adolescente, em separado ou na companhia dos pais, de responsável ou de pessoa por si indicada, bem como os seus pais ou responsável, têm direito a ser ouvidos e a participar nos atos e na definição da medida de promoção dos direitos e de proteção, sendo sua opinião devidamente considerada pela autoridade judiciária competente, observado o disposto nos $\S \S 1$ e e 2 o do art. 28 desta Lei.

\subsection{As formas de colocação em família substituta: guarda, tutela e adoção}

A Constituição Federal de 1988 determina que "a família é a base da sociedade" (artigo 226) e que cabe a ela, juntamente com a comunidade e o Estado, "assegurar à criança e ao adolescente o exercício de direitos fundamentais" (artigo 227). Esta é, também, a função da família substituta. Priorizando a convivência familiar como um direito fundamental da infanto-adolescência, o Estatuto estabeleceu no artigo 19 que "toda criança ou adolescente tem o direito 
de ser criado e educado no seio de sua família e, excepcionalmente, em família substituta, assegurada a convivência familiar e comunitária ${ }^{19}$.

Das palavras de Tânia da Silva Pereira acima transcritas estão a regra geral, de permanência na família natural, e a excepcional, de colocação em família substituta, consoante o que consta no caput do artigo 28 do ECA, “A colocação em família substituta far-se-á mediante guarda, tutela ou adoção, independentemente da situação jurídica da criança ou adolescente, nos termos desta Lei”. Em todas, a família deve refletir “ambiente familiar adequado", a teor do que dispõe o artigo 29, também do Estatuto.

Essa colocação em família substituta não deve ser feita de forma arbitrária ou aleatória, pois na inexistência de família extensa ou ampliada, com a qual a criança ou adolescente tenha afinidade e afetividade, exige a Lei que a colocação se faça com preparação gradativa por equipe interprofissional do Juizado (artigo $\left.28, \S 5^{\circ}, \mathrm{ECA}\right) .^{20}$

Em relação à participação da criança e do adolescente na sua colocação em família substituta, oportuna a citação do $\S 1^{\circ}$ do $\operatorname{artigo} 28$ da ECA, segundo o qual

Sempre que possível, a criança ou o adolescente será previamente ouvido por equipe interprofissional, respeitado seu estágio de desenvolvimento e grau de compreensão sobre as implicações da medida, e terá sua opinião devidamente considerada

Assim, quando o dispositivo supracitado fala em "oitiva sempre que possível" da opinião da criança e do adolescente o objetivo é auxiliar o magistrado na tomada de decisões. $\mathrm{E}$ isto decorre do direito de opinião e expressão a eles garantidos enquanto sujeitos de direitos. Soma-se a isso, a inclusão realizada pela Lei 12.010/2009 no $\$ 2^{\circ}$ do mesmo artigo 28 do Estatuto, ao estabelecer que "Tratando-se de maior de 12 (doze) anos de idade, será necessário seu consentimento, colhido em audiência”. Mais do que considerar a opinião do maior de 12 anos, a lei é expressa ao fazer

\footnotetext{
${ }^{19}$ PEREIRA, Tania da Silva. Direito da Criança e do Adolescente, uma proposta interdisciplinar, $2^{\mathrm{a}}$ ed.. Editora Renovar, 2008.p. 377.

${ }^{20}$ FONSECA, Antonio Cesar Lima da. Direitos da criança e do adolescente. $2^{\mathrm{a}}$ ed.. São Paulo: Ed. Atlas, 2012. p. 103.
} 
referência à necessidade de seu consentimento para que se processe a guarda, a tutela ou a adoção.

A guarda está disciplinada nos artigos 33 a 35 do Estatuto da Criança e do Adolescente. Quando falamos que uma criança está sob guarda, o que se quer dizer é que alguém tem a obrigação, determinada por lei ou por decisão judicial, de manter sob sua autoridade e proteção, outra pessoa. " $E$ ato formal que exige a lavratura de termo próprio de declaração, após a oitiva dos pais pelo Magistrado e pelo Ministério Público $\left(\$ 1^{\circ}\right.$ do artigo 166 do ECA $)^{21}$ " Além disso, cumpre esclarecer que a guarda coexiste ao poder familiar. Desse modo, a autoridade exercida pelos genitores continua. Apenas alguns encargos da guarda e responsabilidades são transferidos. Ela pode ser provisória ou definitiva.

Tem-se diferenciado as espécies de guarda, dependendo de seu tempo de duração ou de sua origem. Sob o primeiro aspecto, tem-se dito que guarda provisória é aquela deferida por um determinado tempo, arbitrado pelo magistrado, normalmente pelo período entre 30 e 90 dias, no curso do processo de guarda, podendo também ser deferida nos procedimentos de tutela e adoção (...) A guarda provisória, portanto, é indispensável como medida preliminar, a título de estágio da criança, junto à entidade familiar substituta $(. . .)^{22}$.

Quando há a impossibilidade momentânea do exercício da guarda pelos pais e por outros parentes surge a figura da guarda subsidiada ou por incentivo, através da qual busca-se recursos sociais junto a programas assistenciais, de forma que a criança ou o adolescente sejam acolhidos por pessoas previamente cadastradas e que se responsabilizarão por meio de termo próprio de guarda. Há a guarda legal do dirigente da entidade de acolhimento institucional nos casos em que o infante precisa ser afastado do convívio familiar para resguardar a sua proteção. Dessa forma, o acolhimento institucional surge como medida que pode ser utilizada em situação emergencial, hipótese em que o representante legal da entidade será considerado guardião.

\footnotetext{
${ }^{21}$ MACIEL, Kátia R. F. L. A. Curso de direito da criança e do adolescente: aspectos teóricos e práticos. $4^{a}$ ed.. Rio de Janeiro: Editora Lumen Juris, 2010. p 156. (trecho de Kátia Regina Ferreira Lobo Andrade Maciel).

${ }^{22}$ Ibid.
} 
Passamos a falar, em linhas gerais, da tutela, outra forma de colocação em família substituta, com disposições gerais nos artigos 36 a 38 do Estatuto, e que também foi tratada no Código Civil de 2002, artigos 1.728 a 1.766.

A diferença entre a tutela estatutária e a do Código Civil é a de que esta é mais ampla, com finalidade própria de proteção do menor, independentemente de sua inserção em família substituta. A tutela do Estatuto é tutela destinada à criança e/ou adolescente nas condições do artigo 98, incisos, do ECA, apenas. ${ }^{23}$

Os incisos do artigo 98 do Estatuto trazem as situações de aplicação das medidas de proteção quando os direitos das crianças e dos adolescentes forem ameaçados: "I - por ação ou omissão da sociedade ou do Estado; II por falta, omissão ou abuso dos pais ou responsável; III - em razão de sua conduta."

Por assim ser, a tutela decorre da perda do poder familiar. É mais ampla do que a guarda porque substitui, integralmente, a autoridade parental.

A tutela consiste no encargo ou múnus conferido a alguém para que dirija pessoa e administre os bens de menores de idade e que não incide no poder familiar do pai ou da mãe (...) Falecendo um dos pais, o poder parental concentra-se no outro, ainda que este venha a contrair novas núpcias. Falecendo ambos, ou sendo declarados ausentes, os filhos menores são postos em tutela. Igualmente incide na tutela o filho que não atingiu a maioridade, se os pais decaírem do poder familiar ${ }^{24}$.

Abaixo, segue quadro esquematizado acerca dos efeitos que as três formas de colocação em família substituta geram no poder familiar, poder a ser analisado no item a seguir, 1.6, em especial, a sua relação com a adoção, objeto deste estudo.

\footnotetext{
${ }^{23}$ FONSECA, Antonio Cezar Lima. Direitos da Criança e Adolescente. $2^{\mathrm{a}}$ ed.. São Paulo: Ed. Atlas, 2012. p. 128.

${ }^{24}$ PEREIRA,Caio Mário da Silva. Instituições de direito civil. Vol. V, Direito de Família, 2009, p. 467.
} 


\begin{tabular}{|c|c|c|c|}
\hline $\begin{array}{c}\text { FORMAS DE } \\
\text { COLOCAÇÃO EM } \\
\text { FAMIILIA } \\
\text { SUBSTITUTA }\end{array}$ & $\leftarrow \rightarrow$ & $\begin{array}{c}\text { EFEITOS NO } \\
\text { PODER } \\
\text { FAMILIAR }\end{array}$ & $\begin{array}{c}\text { Possibilidade de } \\
\text { CESSAÇÃO }\end{array}$ \\
\hline GUARDA & $\leftarrow \rightarrow$ & $\underline{\text { COEXISTÊNCIA }}$ & $\begin{array}{c}\underline{\text { SIM }} \\
\text { (a qualquer tempo) }\end{array}$ \\
\hline TUTELA & $\leftarrow \rightarrow$ & $\underline{\text { PERDA OU }}$ & $\begin{array}{c}\text { MAIORIDADE } \\
\text { ou EMANCIPAÇÃO }\end{array}$ \\
\hline ADOÇÃO & $\leftarrow \rightarrow$ & $\underline{\text { EXTINÇÃO }}$ & $\underline{\text { IRREVOGABILIDADE }}$ \\
\hline
\end{tabular}

Passamos à análise do poder familiar e as suas implicações no instituto da adoção.

\subsection{A adoção e o poder familiar}

A expressão "pátrio poder", elencada no Código Civil de 1916, designava o modelo de família patriarcal do direito romano. Acompanhando a evolução das relações familiares, tal nomenclatura foi, com o Código Civil de 2002, substituída pelo termo "poder familiar". Esta terminologia não é absolutamente nova.

$\mathrm{O}$ entendimento de que a função para exercício do poder familiar deve obrigatoriamente ser partilhada com os pais não é absolutamente novo, na medida em que já estava consagrada no artigo $5^{\circ}$, inciso I, da Constituição Federal de 1988. O Estatuto da Criança e do Adolescente, trilhando a mesma senda, prevê que o pátrio poder (leia-se poder familiar) impõe divisão igualitária de tarefas entre os pais (artigo 21 do ECA). ${ }^{25}$

Das palavras supracitadas extraímos que o legislador quis deixar clara a igualdade entre homens e mulheres de certo que o poder familiar deve ser compreendido como

(...) um poder-dever: é poder, pois traz consigo um elo de autoridade dos pais sobre os filhos menores; é dever, pois obriga ambos os pais ao atendimento integral das necessidades dos filhos. Trata-se de uma estrada de mão dupla, pois impõe deveres e reconhece direitos, não se podendo ignorar que seu exercício se concentra exclusivamente no interesse do menor. ${ }^{26}$

\footnotetext{
${ }^{25}$ MACIEL, Kátia R. F. L A. Curso de direito da criança e do adolescente: aspectos teóricos e práticos. $4^{a}$ ed.. Rio de Janeiro: Editora Lumen Júris, 2010. p. 81. (trecho de Kátia Regina Ferreira Lobo Andrade Maciel).

${ }^{26}$ PERLINGIERI, Pietro. O direito civil na legalidade constitucional. Rio de Janeiro: Renovar, 2008. p.1002.
} 
Sobre o tema, oportuna é a transcrição do artigo 21 do ECA:

O poder familiar será exercido, em igualdade de condições, pelo pai e pela mãe, na forma do que dispuser a legislação civil, assegurado a qualquer deles o direito de, em caso de discordância, recorrer à autoridade judiciária competente para a solução da divergência.

A troca da expressão "pátrio-poder" pela "poder familiar" foi, conforme dito anteriormente, inovação trazida pelo Código Civil de 2002, que seguiu o direcionamento dado pela Constituição Federal e, a teor do que dispõe o seu artigo 1630 e seguintes, estabeleceu o exercício deste poder aos pais durante o casamento e a união estável. Havendo divergência, pode-se recorrer ao Judiciário. Nesta linha,

não é direito absoluto dos pais, uma vez que o atingimento do poder familiar, o seu mau uso em detrimento dos direitos da criança ou do adolescente poderá determinar a interferência do Estado para fazer valer o princípio do melhor interesse. $^{27}$

E mais, é:

complexo de direitos e deveres pessoais e patrimoniais dos pais com relação ao filho menor, não emancipado, e que deve ser exercido no melhor interesse deste último. Sendo um direito-função, os genitores biológicos ou adotivos não podem abrir mão dele e não o podem transferir a título gratuito ou oneroso (...) ${ }^{28}$

Passamos a enfrentar a questão relativa à possibilidade de intervenção do Estado no poder familiar, o que demonstra não ser este poder, de fato, absoluto quando analisamos o elemento escolha presente na adoção intuitu personae. Absoluto ele sempre será no sentido de que em nenhum momento poderão estar desamparados a criança e o adolescente. $\mathrm{E}$ também não será absoluto sobre outro prisma. Há hipóteses de perda e suspensão definidas em lei, conforme dispõe o artigo 24 do ECA: "A perda $e$ a suspensão do poder familiar serão decretadas judicialmente, em

\footnotetext{
${ }^{27}$ FONSECA, Antonio C. L. da. Direitos da Criança e do Adolescente. $2^{\mathrm{a}}$ edição. São Paulo: Ed. Atlas, 2012. p. 75.

${ }^{28}$ MACIEL, Kátia R. F. L. A. Curso de direito da criança e do adolescente: aspectos teóricos e práticos. $4^{\mathrm{a}}$ ed.. Rio de Janeiro: Ed. Lumen Júris, 2010. p. 81. (trecho de Kátia Regina Ferreira Lobo Andrade Maciel).
} 
procedimento contraditório, nos casos previstos na legislação civil, bem como na hipótese de descumprimento injustificado dos deveres e obrigações a que alude o art. 22”. E o artigo 22 traz que "aos pais incumbe o dever de sustento, guarda e educação dos filhos menores, cabendo-lhes ainda, no interesse destes, a obrigação de cumprir e fazer cumprir as determinações judiciais”.

O Código Civil de 2002 regula este assunto nos seus artigos 1635, 1636, 1637 e 1638. Neles, a adoção aparece como forma de extinção do poder familiar. $\mathrm{Na}$ modalidade de adoção intuitu personae, além do consentimento, que é intrínseco ao ato, há também o elemento da escolha. Os pais biológicos entregam o filho para aquele(s) que reúnem condições para tal. Sendo a destituição do poder familiar etapa anterior a qualquer movimentação em relação à adoção, como fica este requisito na adoção intuitu personae? Enfrentaremos tal questão no capítulo 3, sendo fundamental neste momento esclarecer que esta escolha realizada pelos pais biológicos no caso da adoção dirigida é, de certa forma, uma disposição do poder familiar, já que realizada em momento anterior a destituição do mesmo. Desta forma, sendo os genitores ainda os detentores do poder familiar, qualquer ação que modifique isto, e a escolha é um exemplo, poderá ser entendida como um ato de disposição.

\subsection{A adoção e o estágio de convivência}

O estágio de convivência é o período de tempo necessário a propiciar o "conhecimento mútuo entre aqueles que se preparam para a séria e grave vinculação familiar, completa e definitiva ${ }^{29}$ ". É requisito exigido para a concretização da adoção. Era de três anos no Código Civil de 1916 e, a partir de 1990, com o ECA passou a ter prazo fixado pelo Juiz da Infância e da Juventude, nos moldes do artigo 46 - “A adoção será precedida de

\footnotetext{
${ }^{29}$ TAVARES, José de Farias. Comentários ao Estatuto da Criança e do Adolescente. $7^{\mathrm{a}}$. ed.. Rio de Janeiro: Gen-Forense, 2010. p.47.
} 
estágio de convivência com a criança ou adolescente, pelo prazo que a autoridade judiciária fixar, observadas as peculiaridades do caso."-.

Antes das modificações trazidas pela Lei de Adoção, Lei 12.010/2009, o estágio de convivência poderia ser dispensado, conforme o antigo $\S 1^{\circ}$ do artigo 46 do Estatuto, caso o adotando não tivesse mais de um ano de idade ou se, independentemente de sua idade, já estivesse na companhia do adotante durante tempo suficiente a dar ensejo à constituição do vínculo. Posteriormente, a Lei 12.010/2009 alterou o citado dispositivo legal do ECA, que passou a ter a seguinte redação: " $O$ estágio de convivência poderá ser dispensado se o adotando já estiver sob a tutela ou guarda legal do adotante durante tempo suficiente para que seja possível avaliar a conveniência da constituição do vínculo". Assim sendo, é notório que o legislador restringiu as hipóteses de não observância do estágio de convivência, a partir do momento em que não mais permitiu a sua dispensa no caso de o adotando ter idade inferior a um ano. E foi além: mesmo neste caso, ou seja, da criança com menos de um ano de idade, passou o Estatuto a dispor que seja observado um período de adaptação entre adotante e adotando.

O que se observa, em muitos casos, é o estágio de convivência exercido na informalidade, ou seja, sem que o Judiciário e a sua equipe interdisciplinar procedam quanto a sua determinação. Tanto é que comumente este período de convivência informal passa a ser assim vivenciado objetivando cumprir o que exige a parte inicial do caput do artigo 46 do Estatuto, passando a criança a viver com seu "futuro" adotante. A despeito do que preceitua o $\S 2^{\circ}$ do mesmo artigo aqui analisado, de que a "simples guarda de fato não autoriza, por si só, a dispensa do estágio de convivência", acertadas são as palavras de Antonio Cezar Lima da Fonseca sobre esta prática:

Essa inovação trazida pela Lei 12.010/09 teve em vista evitar a simples homologação judicial de situações criadas de maneira irregular. Evidente, isso não pode ser levado como regra absoluta, uma vez que, muitas vezes, a guarda de fato faz-se presente por longo tempo de convivência da criança com os guardiões e mesmo com a autorização e concordância dos pais biológicos. (...) Desta forma, 
restaria apenas aferir as peculiaridades do caso pela equipe interprofissional e pelo julgador, tal como foi determinado no caput do artigo 46 do ECA. Ademais, o fato de a guarda de uma criança ser legal ou fática não pode esconder a anterior constituição de vínculo, ou seja, se a criança já tem vínculo familiar com aqueles que detêm a guarda fática, não é o fato de a guarda não ser legal que vai desmerecê-lo. Por outro lado, se é verdade que devemos ter em vista sempre o princípio do melhor interesse, não tem sentido impor-se novo prazo, em estágio de convivência, desta vez por guarda legal, para crianças e adolescentes que já são tratados sob guarda fática como se pertencessem à família adotante. ${ }^{30}$

Com o passar do tempo, vínculos afetivos poderão ser construídos, e se assim fizerem presentes, corresponderão à situação fática, juntamente com a observância do melhor interesse da criança ou do adolescente, suficiente à procedência de um futuro pedido de adoção.

\subsection{Quadro comparativo das legislações}

\begin{tabular}{|c|c|c|}
\hline & $\begin{array}{c}\text { CÓDIGO CIVIL } \\
\text { de } \\
1916 \\
\end{array}$ & $\begin{array}{c}\text { ECA, } \\
\text { CÓDIGO CIVIL de } 2002 \mathrm{e} \\
\text { LEI 12.010/2009 } \\
\end{array}$ \\
\hline ADOTANDO & & $\begin{array}{l}\text { - Idade máxima de } 18 \text { anos na } \\
\text { data do requerimento de adoção } \\
\text { (ECA) e possibilidade do } \\
\text { adotando ter mais de } 18 \text { anos } \\
\text { (pelo Código Civil); } \\
\text { - Consentimento do adotando } \\
\text { com mais de } 12 \text { anos de idade; } \\
\text { - Consentimento dos pais ou } \\
\text { representante legal }\end{array}$ \\
\hline ADOTANTE & $\begin{array}{l}\text { - Maior de } 30 \text { anos de idade; } \\
\text { - Se casado, somente após } 05 \\
\text { anos de matrimônio. }\end{array}$ & $\begin{array}{l}\text { _Maior de } 18 \text { anos; } \\
\text { _Independentemente do estado } \\
\text { civil. }\end{array}$ \\
\hline $\begin{array}{c}\text { DIFERENÇA } \\
\text { DE } \\
\text { IDADE } \\
\end{array}$ & $\begin{array}{l}-18 \text { anos, reduzidos para } 16 \\
\text { pela Lei no. } 3.133 / 57\end{array}$ & $\begin{array}{l}\text { Adotante pelo menos } 16 \text { anos } \\
\text { mais velho que o adotando. }\end{array}$ \\
\hline FORMALIDADE & _ Por escritura pública. & __ Por sentença constitutiva. \\
\hline ESTÁGIO & & \\
\hline
\end{tabular}

${ }^{30}$ FONSECA, Antonio C. L. da. Direitos da Criança e do Adolescente. 2a. ed.. São Paulo: Ed. Atlas, 2012. pp. 427-428. 


\begin{tabular}{|c|c|c|}
\hline $\begin{array}{c}\text { DE } \\
\text { CONVIVÊNCIA }\end{array}$ & - 03 anos. & _ Fixado pelo juiz. \\
\hline RESOLUÇÃO & $\begin{array}{l}\text { _ Por mútuo acordo ou } \\
\text { unilateral }\end{array}$ & _ Irrevogável \\
\hline PARENTESCO & $\begin{array}{l}\text { _ Somente entre adotante e } \\
\text { adotando }\end{array}$ & $\begin{array}{l}\text { - Sem exceções (como se } \\
\text { biologicamente gerado fosse) }\end{array}$ \\
\hline SUCESSÃO & $\begin{array}{l}\text { - Se o adotante tivesse filhos: } \\
\text { não havia sucessão hereditária } \\
\text { para o adotando. Se após a } \\
\text { adoção nascesse um filho } \\
\text { natural, o adotante teria direito } \\
\text { a apenas } 50 \% \text { do que o filho } \\
\text { natural recebesse. }\end{array}$ & _ Sim (sem exceções) \\
\hline
\end{tabular}




\section{CAPÍTULO 2. OS CADASTROS DE ADOÇÃO ESTADUAIS E NACIONAL}

\subsection{Os cadastros regionais previstos no Estatuto da Criança e do Adolescente}

O velho Código de Menores, revogado em 1990, desconhecia a necessidade de criação de cadastros de adoção. Este quadro mudou com a entrada em vigor do Estatuto da Criança e do Adolescente, que passou a prever a manutenção destes cadastros no seu artigo 50, in verbis: " $A$ autoridade judiciária manterá, em cada comarca ou foro regional, um registro de crianças e adolescentes em condições de serem adotados e outro de pessoas interessadas na adoção." Este dispositivo, que passou a prever os cadastros regionais, refletiu a tentativa do legislador de construir um sistema integrado, aproximando possíveis adotandos de possíveis adotantes, estreitando laços com o objetivo de se atender sempre o melhor interesse da criança e do adolescente.

$\mathrm{Na}$ origem, isto é, quando da criação do ECA, a gestão das informações sobre crianças e adolescentes aptos à adoção e os seus pretendentes era regionalizada, a teor do que dispõe o artigo supra referenciado. Como consequência, passou-se a perceber que tal segmentação acabaria por levar à redução das chances de ocorrência de um número maior de adoções e frustraria o objetivo de construção de um sistema favorável a esta forma de colocação da criança e do adolescente em família substituta. Assim sendo, nossas disposições legais precisavam evoluir e a Lei 12.010/2009 introduziu algumas novidades no Estatuto. Os parágrafos $3^{\circ}$ ao 13 foram incluídos pela referida lei de adoção ao artigo 50 do ECA, passando a pormenorizar, dentre outros aspectos: a necessidade de preparação psicossocial e jurídica anterior à inscrição de postulantes a adoção; a inclusão do contato com a criança ou o adolescente; o acesso 
integral aos cadastros pelas autoridades estaduais e federais; a criação e a implementação do Cadastro Nacional de Adoção (CNA) e do posterior Cadastro Nacional de Crianças e Adolescentes Acolhidos (CNCA), sobre os quais falaremos a seguir.

\subsection{O Cadastro Nacional de Adoção (CNA) e o Cadastro Nacional de Crianças e Adolescentes Acolhidos (CNCA) implantados pelo Conselho Nacional de Justiça}

Em 2007, o sistema de adoção deu um passo à frente. Com a criação do Conselho Nacional de Justiça ${ }^{31}$ (CNJ) e após um encontro que reuniu os Tribunais de Justiça de todos os estados da federação, foi discutida e esboçada a criação de um cadastro nacional. No ano seguinte, em 29 de fevereiro, por meio da Portaria número 214 (ANEXO 2), o CNJ instituiu o Comitê Gestor do Cadastro Nacional de Adoção, no âmbito do próprio CNJ, com competência para oferecer subsídios, acompanhar o desenvolvimento e adotar as providências necessárias à implementação do Cadastro Nacional de Adoção (CNA).

Logo após, o CNJ editou a Resolução no. $54{ }^{32}$ (ANEXO 3), de 29 de abril de 2008, que implantou o Cadastro Nacional de Adoção e fixou o

\footnotetext{
31 verifica-se que o CNJ possui atribuição de controle do Poder Judiciário, tal controle, consoante legislação vigente, diz respeito a um controle administrativo, que possui índole interna, isto é, um controle em que não prejudica a autonomia e a independência do Poder Judiciário, mas sim, o organiza. Esta característica foi (re)firmada na decisão do STF que julgou improcedente a ADI 3365, a qual foi intentada pela AMB (Associação dos Magistrados do Brasil), que entendia ser o CNJ um órgão de controle jurisdicional e, portanto, inconstitucional, pois de encontro com a autonomia do Judiciário (...)Várias reflexões foram feitas referentes ao Conselho Nacional de Justiça, entre elas está a real competência que o CNJ possui dentro do Poder Judiciário. De forma indiscutível, o CNJ, teoricamente, possui atribuição administrativa, isto frente a lei que o instituiu $(\mathrm{CF})$ e as decisões posteriores a sua criação. Ocorre, que na prática, parece que o órgão em questão tem tomado novos rumos, passando a trazer para si atribuições de cunho jurisdicional e legislativo, sem que isso seja o entendimento do órgão superior do Judiciário: o STF. Disponível em: http://www.ambito-

juridico.com.br/site/index.php?n_link=revista_artigos_leitura\&artigo_id=9498. Acesso em $16 / 10 / 2013$.

$32 \quad$ Disponível em: http://www.cnj.jus.br/atos-administrativos/atos-dapresidencia/resolucoespresidencia/12169-resolu-no-54-de-29-de-abril-de-2008. Acesso em 17/09/2013.
} 
prazo de 180 dias para que todas as informações relativas a adotantes e adotandos fossem inseridas nesse cadastro. A Resolução $\mathrm{n}^{\circ} 54$ teve alguns pontos incluídos posteriormente por outra Resolução, a de $n^{\circ} 93 / 2010^{33}$, (ANEXO 4), que previu a criação do Cadastro Nacional de Crianças e Adolescentes Acolhidos (CNCA). Os dados do CNA foram, então, complementados pelo CNCA, já que este passou a fornecer informações sobre crianças e adolescentes que estivessem em entidades de acolhimento e/ou estabelecimentos mantidos por organizações não-governamentais, instituições religiosas e igrejas.

Dessa forma, em termos de cadastros, temos, desde a primeira edição (Estatuto da Criança e do Adolescente) até as últimas atualizações:

\begin{tabular}{|c|c|c|c|}
\hline ANO & DISPOSITIVO & & MEDIDA \\
\hline 1990 & $\begin{array}{c}\text { ECA, artigo 50: } \\
\text { “A autoridade judiciária } \\
\text { manterá, em cada comarca ou } \\
\text { foro regional, um registro de } \\
\text { crianças e adolescentes em } \\
\text { condiçóes de serem adotados e } \\
\text { outro de pessoas interessadas } \\
\text { na adoção." }\end{array}$ & $\leftarrow \rightarrow$ & $\begin{array}{c}\text { Previsão de criação de cadastros } \\
\text { regionais }\end{array}$ \\
\hline 2008 & Resolução n ${ }^{\circ} 54, \mathrm{CNJ}$ & $\leftarrow$ & $\begin{array}{l}\text { Implantação do CNA (Cadastro } \\
\text { Nacional de Adoção) }\end{array}$ \\
\hline 2009 & $\begin{array}{c}\text { Lei } 12.010 / 2009 \\
\text { acrescentou } \S \S \text { ao artigo } 50 \text { do } \\
\text { ECA } \\
\S 5^{\circ} \text { : "Serão criados e } \\
\text { implementados cadastros } \\
\text { estaduais e nacional de } \\
\text { crianças e adolescentes em } \\
\text { condições de serem adotados e } \\
\text { de pessoas ou casais } \\
\text { habilitados à adoção." }\end{array}$ & $\leftarrow \rightarrow$ & $\begin{array}{l}\text { Lei de Adoção formalizou o que } \\
\text { fora anteriormente previsto pela } \\
\text { Resolução }{ }^{\circ} 54 \text { do CNJ }\end{array}$ \\
\hline 2010 & Resolução nº 93, CNJ & $\leftarrow \rightarrow$ & $\begin{array}{l}\text { Implantação do CNCA } \\
\text { (Cadastro Nacional de Crianças e } \\
\text { Adolescentes Acolhidos) }\end{array}$ \\
\hline
\end{tabular}

33 Disponível em: $\quad$ http://www.cnj.jus.br/atos-administrativos/atos-dapresidencia/resolucoespresidencia/12216-resolucao-no-93-de-27-de-outubro-de-2009. Acesso em $\underline{17 / 09 / 2013 .}$. 
O CNA, como banco de dados nacional que é, padroniza todos os cadastros regionais com informações necessárias à realização de adoções no Brasil, abrangendo todas as comarcas das unidades da federação. Importante frisar que o cadastro nacional não substitui o estadual, que continua em vigor. Ele apenas unificou as informações da federação de forma a se ter um banco de dados a nível nacional. Através dele é possível que as Corregedorias Gerais de Justiça, administradoras do sistema a nível regional, controlem todo o processo de forma adequada, tendo, para isso, acesso às informações do cadastro referentes ao seu respectivo estado. Para Luciano Alves Rossato e Paulo Eduardo Lépore, é benéfica a existência de um cadastro nacional e "trata-se de mecanismo que possibilita o cruzamento de dados e a rápida identificação de crianças ou adolescentes institucionalizadas. Tal expediente permite, ainda, o intercâmbio de informações entre comarcas e regiões ${ }^{34}$ ". Bordallo também elogia a opção do legislador em instituir os cadastros ao afirmar que "é bastante útil pois facilita a apuração dos requisitos legais e facilita a compatibilidade entre adotante e adotando pela equipe interprofissional, o que tornará mais céleres os processos de adoção ${ }^{35 "}$.

Já a administração do sistema a nível nacional fica a cargo da Corregedoria Nacional de Justiça, que tem o dever de manter o funcionamento do CNA e de aperfeiçoá-lo, sempre visando atingir os objetivos estabelecidos e garantindo a segurança dos dados nele contidos. Assim, uma consulta a pretendentes à adoção, deve iniciar-se na Comarca, passando para o cadastro estadual, e se não resultar positiva é que se fará a consulta no cadastro nacional.

$\mathrm{Na}$ esfera estadual, cada Corregedoria-Geral tem acesso às informações do CNA referentes ao seu estado, sendo de sua competência o

\footnotetext{
${ }^{34}$ ROSSATO, Luciano Alves; LÉPORE, Paulo Eduardo. Comentários à Lei Nacional de Adoção Lei 12.010, de 03 de agosto de 2009. São Paulo: Revista dos Tribunais. 2009. p. 55.

35 BORDAllo, Galdino Augusto Coelho“Adoção", In: Curso de Direito da Criança e do Adolescente: aspectos teóricos e práticos. $4^{\mathrm{a}}$ ed.. São Paulo: Lumen Juris, 2010. p. 224.
} 
cadastramento das Comarcas e Varas da Infância e da Juventude de seu tribunal. Os dados do cadastro podem ser acessados somente por: juízes de direito das Varas da Infância e Juventude, promotores de Justiça com atribuição para a infância e juventude e com competência para a adoção, Corregedorias-Gerais de Justiça, Comissões Estaduais Judiciárias de Adoção (Cejas), Comissões Estaduais Judiciárias de Adoção Internacional (Cejais), e órgãos autorizados pelo CNJ, tais como a Secretaria Especial de Direitos Humanos da Presidência da República e outros que venham a receber autorização.

Para melhor visualização dos cadastros, segue tabela:

\begin{tabular}{|l|l|l|}
\hline \multicolumn{3}{|c|}{ CADASTROS } \\
\hline & $\begin{array}{l}\text { ADMINISTRADO } \\
\text { POR }\end{array}$ & $\begin{array}{l}\text { INFORMAÇÕES } \\
\text { SOBRE }\end{array}$ \\
\hline $\begin{array}{l}\text { NÍVEL NACIONAL } \\
\text { (CNA propriamente dito) }\end{array}$ & $\begin{array}{l}\text { Corregedoria Nacional } \\
\text { de Justiça }\end{array}$ & $\begin{array}{l}\text { cada um dos cadastros } \\
\text { estaduais }\end{array}$ \\
\hline $\begin{array}{l}\text { NÍVEL ESTADUAL } \\
\text { (porque composto pelos estaduais, } \\
\text { que por sua vez são compostos por } \\
\text { "n"comarcas }\end{array}$ & $\begin{array}{l}\text { Corregedorias Gerais } \\
\text { de Justiça }\end{array}$ & $\begin{array}{l}\text { seu próprio estado } \\
\text { (comarcas) }\end{array}$ \\
\hline
\end{tabular}

Os postulantes à adoção com domicílio no Brasil deverão dirigir-se à Vara da Infância e da Juventude da Comarca de sua residência, onde apresentarão uma espécie de petição inicial, ou seja, um requerimento com os documentos indicados no artigo 197-A do ECA: qualificação completa; dados familiares; cópias autenticadas de certidão de nascimento ou casamento, ou declaração relativa ao período de união estável; cópias da cédula de identidade e inscrição no Cadastro de Pessoas Físicas; comprovante de renda e domicílio; atestados de sanidade física e mental; certidão de antecedentes criminais; e certidão negativa de distribuição cível. Documentos que acreditamos serem exigidos para dar maior segurança ao 
processo, de forma que aqueles que venham a integrar o cadastro, pelo menos, sejam pessoas teoricamente idôneas.

O pretendente à adoção somente poderá ser inserido no sistema pela Comarca de seu domicílio, nos moldes do art. 50 da Lei Federal 8.069/90. Isso significa que o pretendente deve primeiro habilitar-se na Vara da Infância e da Juventude de sua Comarca ou, inexistindo nela Vara Especializada, na Vara competente para o processo de adoção. O próprio juiz ou seu auxiliar realizará o cadastro no sistema. Com a inserção no CNA, todos os juízes, de todo o país, terão acesso à relação dos pretendentes à adoção. ${ }^{36}$

O objetivo de todo o cadastro é ordenar a colocação de crianças e adolescentes em família substituta na modalidade de adoção. Para isso, em regra, obedece à anterioridade dos interessados e às peculiaridades de cada caso quanto à pessoa a ser adotada. Também tem por objetivo preparar os pretendentes à adoção para os pormenores do instituto, o que será fundamental para o posterior sucesso da convivência familiar. A habilitação é um procedimento de natureza administrativa e por assim ser dispensa a assistência de advogado. É o que está disposto na redação do artigo 197-A, anteriormente citado. De outra forma, cumpre lembrar que o pedido de adoção é feito com assistência de advogado.

Em relação ao Cadastro Nacional de Crianças e Adolescentes (CNCA), este foi feito para complementar o banco de dados do Cadastro Nacional de Adoção (CNA). Enquanto o CNA possui informações apenas sobre as crianças aptas à adoção, o CNCA conterá dados sobre todas as crianças e adolescentes, destituídas ou não do poder familiar, que se encontram em entidades de acolhimento. Os dois cadastros, gerenciados pela Corregedoria Nacional de Justiça, ajudam a resolver os principais entraves que atrapalham o processo de adoção e recuperação de adolescentes em conflito com a Lei.

\footnotetext{
36 Disponível em: <http://www.cnj.jus.br/images/programas/cadastro-adocao/guia-usuarioadocao.pdf - página 10>. Acesso em 03/10/2013.
} 


\begin{tabular}{|c|l|l|}
\hline $\begin{array}{c}\text { CADASTRO } \\
\text { NACIONAL DE } \\
\text { ADOÇÃO } \\
\text { (CNA) }\end{array}$ & $\leftrightarrow$ & $\begin{array}{l}\text { Possui informações apenas sobre } \\
\text { crianças/adolescentes aptas à adoção. }\end{array}$ \\
$\begin{array}{c}\text { CADASTRO } \\
\text { NACIONAL DE } \\
\text { CRIANÇAS E } \\
\text { ADOLESCENTES } \\
\text { (CNCA) }\end{array}$ & $\leftrightarrow \rightarrow$ & $\begin{array}{l}\text { Possui informações sobre todas crianças e } \\
\text { adolescentes que estão em entidades de } \\
\text { acolhimento. }\end{array}$ \\
\hline
\end{tabular}

A validade, em regra, das inscrições contidas no CNA é de cinco anos. Este período pode ser reduzido a critério do juízo da habilitação caso entenda ser prudente a reavaliação dos pretendentes. Se o processo de adoção não for finalizado dentro destes cinco anos, o sistema envia um alerta ao Juízo, que poderá notificar o pretendente para providenciar a renovação do seu pedido, caso, obviamente, tenha interesse.

Outra possibilidade que pode ocorrer é o adotante não encontrar uma criança durante este prazo de cinco anos, situação em que o cadastro do pretendente poderá ser mantido, desde que seja realizada uma reavaliação, com obrigatória atualização dos dados. Além disso, pode também o magistrado suspender os pretendentes por ele habilitados se entender que esta é a melhor forma de proceder, hipótese em que a situação no cadastro será alterada para "inativo por determinação judicial".

Conforme dispõe o CNJ no Guia do Usuário do Cadastro Nacional de Adoção ${ }^{37}$, a baixa da inscrição de pretendentes à adoção ocorrerá por: a) óbito; b) pedido formal de desistência; c) adoção; d) situações que o

37 Disponível em formato pdf em: http://www.paginadocidadao.com.br/cartilha/cartilha-docadastro-nacional-de-adocao-manual-do-usuario. Acesso em 09/11/2013. 
qualifiquem como inapto; e) após 5 (cinco) anos da data de inscrição, caso não tenha sido renovado o pedido e procedida a reavaliação. Em relação às crianças e aos adolescentes inscritos no CNA, a baixa de suas respectivas inscrições dar-se-á por: a) adoção; b) implemento dos 18 anos de idade; c) óbito.

Segundo artigo publicado no portal do CNJ em 03 de janeiro de 2013, “dados de dezembro de 2012 do Cadastro Nacional de Adoção (CNA) revelam que há mais pessoas interessadas em adotar crianças ou adolescentes de qualquer raça. No mesmo mês de 2010, 31,4\% das 30.378 pessoas cadastradas não se importavam com a raça da criança ou do adolescente disponível para adoção. Dois anos depois, a porcentagem cresceu para $37,75 \%$ dos 28.780 pretendentes cadastrados (...)",38. Apesar dos números mostrarem uma evolução no assunto, muitas crianças ainda são recusadas em virtude de cor, idade, defeito físico, doença, etc. Sobre esta recusa, útil que passemos a responder as seguintes perguntas: a pessoa que recusa uma criança/adolescente continua no mesmo lugar na fila? Caso a empatia não se estabeleça nos primeiros contatos, a pessoa está livre para continuar aguardando por outra criança/adolescente no mesmo lugar na fila? Vale destacar, porém, que de acordo com a Nova Lei de Adoção, no artigo 197-E, § 2º "a recusa sistemática na adoção das crianças ou adolescentes indicados importará na reavaliação da habilitação concedida”, hipótese em que se passará ao próximo pretendente da fila. No entanto, tal dispositivo é de interpretação aberta, pois o legislador não fixou quantas vezes são necessárias para que se dê ensejo à reavaliação da habilitação.

Se pensarmos somente na fila do cadastro, estaremos fechando os olhos para conjecturas nas quais a criança já convive sob laços familiares e já constitui vínculos de afeto, situações já formalizadas como guarda, tutela. Ou, até mesmo, situações de entrega informal, isto é, sem o crivo do Poder

38 Disponível em: http://www.cnj.jus.br/noticias/cnj/22951-aumenta-numero-de-adotantesindiferentes-a-raca-de-criancas. Acesso em 07/10/2013. 
Judiciário e baseado apenas na decisão da pessoa que dá seu (sua) filho(a) a alguém determinado. Em qualquer dos casos, mandar a criança obrigatoriamente para a fila somente para atender ao mandamento contido no caput do artigo 50 do Estatuto pode significar fechar os olhos para o seu melhor interesse. Soma-se a isso a possibilidade dessa criança ser recusada pelo primeiro casal da fila de adotantes por estes quererem um(a) filho(a) com outro perfil. Nestes casos, vemos mais um motivo para que se considere a legalidade da adoção intuitu personae, sobre a qual falaremos no capítulo 3. Mais vantagem terá a criança ao permanecer com quem já estabeleceu afeto, em detrimento de mandá-la ao cadastro. Sobre este impasse, são acertadas as palavras de Bordallo no sentido de que, em determinadas situações, faz-se necessário o desrespeito ao cadastro:

Não se justifica que em nome ao respeito a uma regra que tem a finalidade única de dar publicidade e legalidade às adoções, o sentimento, o sustentáculo da adoção, seja colocado em segundo plano e a criança seja obrigada a passar por outro drama em sua vida, sair da companhia de quem aprendeu a amar. ${ }^{39}$

Tendo em vista a obrigatoriedade da preparação psicossocial dos interessados, o que está intimamente ligado ao processo de habilitação sobre o qual passaremos a analisar, o que se espera é que a lei possa, ao menos, preparar os pretendentes para abrirem seus universos de escolhas, objetivando, primeiramente, dar prioridade à proteção integral das crianças e adolescentes que estão à espera de uma família e de um lar seguro.

\subsection{A necessidade de habilitação como condição prévia à inscrição no cadastro de adotantes e a sua possível flexibilização}

A teor do que dispõe o artigo 50 do Estatuto, da criação e implantação de cadastros estaduais e nacional de crianças e adolescentes aptos à adoção, importa analisar, neste momento, a parte final do seu parágrafo $5^{\circ}$, que assim dispõe: "cadastros estaduais e nacional de

\footnotetext{
39 BORDALLO, Augusto Galdino Coelho. "Adoção", In: Curso de Direito da Criança e do Adolescente: aspectos teóricos e práticos. $4^{\mathrm{a}}$ Ed. São Paulo: Lumen Juris, 2010, p. 228.
} 
crianças e adolescentes em condições de serem adotados e de pessoas ou casais habilitados à adoção”. Tal dispositivo faz menção à necessidade de habilitação como requisito prévio à inserção no cadastro de pretendentes à adoção, uma das inovações introduzidas pela Lei n. 12.010/2009. A referida inclusão ocorre por determinação judicial após prévia sentença de habilitação, nos moldes do artigo 197-E do ECA, "Deferida a habilitação, o postulante será inscrito nos cadastros referidos no art. 50 desta Lei, sendo a sua convocação para a adoção feita de acordo com ordem cronológica de habilitação e conforme a disponibilidade de crianças ou adolescentes adotáveis".

O pedido de habilitação poderá ser feito por pessoas maiores de 18 anos de idade, independente do estado civil, desde que atenda aos requisitos legais para a adoção previstos no Estatuto da Criança e do Adolescente. Nada impede que este pedido seja efetivado em formulário proposto pelos Tribunais e fornecidos pela Vara da Infância e da Juventude, visando unificar a coleta de informações até mesmo para fins estatísticos. Quanto à competência, o interessado deve cadastrar-se junto ao Juízo de seu domicílio, não havendo necessidade de se formular pedidos em vários juízos, até porque tais dados estaduais serão unificados a nível nacional pelo CNA. No entanto, se ocorrer mudança de cidade que implique em mudança de Estado, o interessado deve dar início a novo cadastro junto ao Juizado da Infância e da Juventude de onde passar a residir. Desse modo, o legislador optou por inserir na legislação estatutária uma normatividade que viesse unificar os procedimentos quanto ao cadastro. Pela literalidade dos artigos supracitados, a regra geral é a de que a habilitação aparece como requisito anterior e obrigatório ao deferimento do pedido de adoção. A contrário senso, entende-se que a adoção somente será deferida a pessoas previamente habilitadas. 
No Manual de Adoção criado pela Associação dos Magistrados Brasileiros (AMB), "Adoção Passo a Passo" ${ }^{40}$, destaca-se a atuação de equipes interdisciplinares nas Varas da Infância e da Juventude, fundamentais para o sucesso do processo de habilitação, consoante disposto no artigo 197-C - "Intervirá no feito, obrigatoriamente, equipe interprofissional a serviço da Justiça da Infância e da Juventude, que deverá elaborar estudo psicossocial, que conterá subsídios que permitam aferir a capacidade e o preparo dos postulantes para o exercício de uma paternidade ou maternidade responsável, à luz dos requisitos e princípios desta Lei."-. São psicólogos, assistentes sociais e outros profissionais que buscam verificar se determinada pessoa que se candidata a adotante realmente tem condições reais, nos mais diferentes planos, de receber a criança e/ou adolescente em um ambiente, de fato, familiar. Assim sendo, a habilitação compreende todos os procedimentos de cadastro e análise dos possíveis candidatos, incluindo diversas entrevistas, que procuram verificar as reais condições dos candidatos.

(...) as entrevistas objetivam conciliar as características das crianças/adolescentes que se encontram aptas à adoção com as características das crianças pretendidas pelos adotantes; identificar possíveis dificuldades ao sucesso da adoção e fornecer orientações. (...) Aos profissionais que trabalham com adoção cabe a responsabilidade de entregar crianças que estão sob a guarda do Estado, cuidando para que a adoção se processe dentro de padrões éticos. ${ }^{41}$

Feita a habilitação, os candidatos a adotantes passam a integrar $o$ cadastro de habilitados e, conforme dito anteriormente, podem ser reavaliados a qualquer tempo pelo magistrado.

A regra geral é a de que a adoção tem como etapa anterior ao seu deferimento a habilitação. No entanto, toda regra comporta algum tipo de exceção. Assim, oportuno voltar a citar palavras de Caio Mário da Silva Pereira, que traz as hipóteses nas quais é possível dispensar a habilitação:

\footnotetext{
40 "Adoção passo a passo", disponível para download em http://www.amb.com.br/mudeumdestino/?secao=cartilhas. Acesso em 09/11/2013.
}

\footnotetext{
${ }^{41}$ Manual de Adoção da AMB, Capítulo IV, p. 19.
} 
(...) na inexistência de interessados habilitados ou em casos excepcionais, como na existência de vínculo afetivo já constituído entre adotantes e adotado ou já estando a criança ou adolescente em companhia de adotantes por tempo suficiente a se poder avaliar a conveniência da constituição do vínculo. ${ }^{42}$

Aqueles que entendem ser o respeito à ordem dos cadastros e à anterior habilitação dos pretendentes como absolutos não consideram que a melhor forma de enfrentar a sistemática da adoção é analisá-la no caso concreto, sob pena de se comprometer a proteção integral da criança e do adolescente e a posição de sujeitos de direito que eles passaram a ocupar com a nova ordem constitucional de 1988, qualidades tão fortemente preconizadas pelo nosso ordenamento.

Em que pese tratar-se de um cadastro nacional das duas partes interessadas, ou seja, adotantes e adotandos, na prática, o que se observa é a existência de um cadastro muito mais voltando para os pretendentes à adoção. Basta ver que o primeiro casal da fila, caso não se interesse pela primeira criança do cadastro, passará para a segunda. Seguindo este raciocínio, a pergunta a ser respondida é: como fica a primeira criança, a que foi recusada? Estaria o cadastro, assim, privilegiando o mandamento de proteção integral da criança e do adolescente? O assunto é delicado e a advogada e estudiosa do Direito, Elisabeth Schreiber, faz esses questionamentos, apontando a necessidade de que o centro dos interesses discutidos em adoção seja o do adotando.

Importante ressaltar que, antigamente, a finalidade da adoção era dar filhos a quem não os tivesse. Atualmente, esse quadro inverte-se: a adoção serve para dar uma família ao adotando, prevalecendo, portanto, o interesse da criança. É uma medida de proteção aos direitos da criança e do adolescente, e não um mecanismo de satisfação de interesses de adultos. Trata-se, sempre de encontrar uma família adequada a uma determinada criança, e não buscar uma criança para aqueles que querem adotar. ${ }^{43}$

\footnotetext{
$\overline{{ }^{2} 2}$ PEREIRA, Caio Mário da Silva. Instituições de direito civil. Vol. V. Direito de Família, 2009. p. 425.

${ }^{43}$ SCHEREIBER, Elisabeth. Os direitos fundamentais da criança na violência intrafamiliar. Porto Alegre: Ricardo Lenz Editor, 2001. p.33.
} 
Em relação ao primordial foco no interesse da criança ou do adolescente, ou seja, daquele que está sendo adotado, relevante registrar o caso da menina Maria Eduarda, de 4 anos e 5 meses de idade. Ela é a protagonista de uma disputa judicial entre a família que a adotou e os pais biológicos. Em 2009, para investigar denúncias de maus tratos, o Ministério Público solicitou à Justiça a destituição do poder familiar e encaminhou a criança, na época com 2 meses de vida, a instituição de acolhimento. Duda lá permaneceu por 2 anos e foi entregue provisoriamente a casal cadastrado. Ocorre que ao longo do processo de destituição do poder, os pais biológicos conseguiram mostrar à Justiça que se reabilitaram. Dessa forma, em decisão unânime, três desembargadores da $7^{\mathrm{a}}$ Câmara Civil do TJMG entenderam que a criança deveria voltar à família biológica, onde viveria com os pais e seis irmãos. O retorno da criança aos genitores, no entanto, foi suspenso, conforme decisão liminar do desembargador Caetano Levy, mas, em 24/10/2013, o desembargador Belizário de Lacerda indeferiu a referida medida de suspensão, determinando o retorno de Duda aos pais biológicos. Sobre essa "coisificação" da criança, acertadas são as palavras de Silvana do Monte Moreira, presidente da Comissão de Adoção do IBDFAM - Instituto Brasileiro de Direito de Família - e diretora Jurídica da ANGAAD Associação Nacional dos Grupos de Apoio à Adoção e Mãe, no artigo “Quem é Duda?":

Duda tem pai, mãe, família extensa, amigos e uma rede social de acolhida. Duda é membro de uma rede familiar e se identifica como tal. Duda tornou-se "objeto" de uma disputa entre o biológico e o afetivo. (...) Duda tem seu melhor interesse atendido pela única família que teve em toda a sua vida. O parágrafo único do artigo 25 do ECA dá o devido valor jurídico ao afeto ao determinar que a família se estende aos familiares com quem a criança conviva e mantenha vínculos de afinidade e afetividade. Quem é essa família? Mais uma vez a única que Duda conhece e de quem a Justiça pretende retirá-la levando ao biologismo a prioridade que jamais teve e nunca poderá ter. A decisão coisifica Duda e considera seus genitores como donos da criança, utilizando a concepção retrógrada do direito romano e acolhida pelo já revogado Código Civil de 1916, de propriedade dos pais sobre os filhos. É necessário que Duda seja vista como sujeito de direitos e que se tenha em mente que ela se encontra em especial estágio de desenvolvimento. Duda tem inúmeros direitos fundamentais que estão sendo desrespeitados em prol de adultos que se provaram incapazes de exercer o poder familiar por toda a vida da criança. Por que o judiciário mineiro entendeu que os 
direitos fundamentais a serem respeitados são os dos genitores e não os de Duda? Não está invertendo a prioridade absoluta pela supremacia dos laços de sangue? Não está rasgando a Constituição Federal? É necessário que se faça valer o tratamento correto, e único, a ser dispensado a crianças, adolescentes e jovens a partir da aplicação do conjunto de normas previstas no Estatuto da Criança e do Adolescente, tendo como bases a Doutrina da Proteção Integral e os princípios da prioridade absoluta e do melhor interesse da criança. Escrevo por Duda, Gabi, JV, Mell, Anita, Valentina, Vitória, Crystal, Vitor, Paulinha, Gabriel, Alexandre, Alysson, Christofer, Letícia, Laura, Zandor, Henrique, João, Giulia, Nina, Fátima, Eduarda, Yasmim, Luana, Mylena, Lucas, Thiago, Matheus, Miguel, Manuel, Heitor, Sabrina, Aurora, Leonardo, Cauã e por todos demais filhos não substitutos de nosso país. Não permitam que nossos filhos sejam relegados a adjetivação, nossos filhos são apenas filhos, da mesma forma que somos somente e tão somente famílias. ${ }^{44}$

\section{Voltando à análise do cadastro, o Promotor de Justiça de Defesa}

Comunitária, Infância e Juventude da Promotoria de Justiça de Osório/RS,

Julio Alfredo de Almeida, o classifica como uma espécie de triagem:

a solução está no correto atendimento da função pública e regulamentadora do cadastro; do caráter preventivo e selecionador que contém; do acolhimento dos aspectos psicológicos tanto do adotado como dos adotantes; na importância do tempo, como fator de formação de vínculos; na idéia de igualdade entre os pretendentes, etc ${ }^{45}$.

Na identificação dos interesses envolvidos, incumbe à equipe técnica selecionar os candidatos a integrantes do cadastro de adoção, avaliando a disposição de cada um deles na função materna e/ou paterna, o que envolve aspectos psicológicos, sociais, capacidade física de lidar com a criança ou com o adolescente e um adequado ambiente familiar. Maria Josefina Becker, uma das autoras do livro Estatuto da Criança e do Adolescente Comentado, ressalta que o cadastro de adotantes reprisa a vida biológica ao esclarecer que

do ponto de vista técnico, pode-se considerar também o processo de seleção como um processo de ajuda aos candidatos, pois durante esse período eles poderão realizar uma avaliação de suas próprias motivações e, quando for o caso, elaborar a aceitação da esterilidade ou infertilidade. Poder-se-ia, mesmo, assemelhar o processo de seleção ao de uma gestação intelectual e emocional. ${ }^{46}$

\footnotetext{
${ }_{44}$ Disponível em: http://www.ibdfam.org.br/artigos/920/Quem+\%C3\%A9+Duda\%3F. Acesso em $31 / 10 / 2013$.

45 ALMEIDA, Julio Alfredo de. Adoção intuitu personae - uma proposta de agir. Fonte: http://www.mprs.mp.br/infancia/doutrina/id393.htm. Acesso em 05/08/2013.

${ }^{46}$ BECKER, Maria Josefina. Estatuto da Criança e do Adolescente Comentado. $3^{\mathrm{a}}$ ed.. São Paulo: Malheiros Editores Ltda, 2000. p. 169.
} 
Toda esta investigação acerca de possíveis e prováveis adotantes, dos pretendentes, nada mais é do que respeito aos artigos 29, “não se deferirá colocação em família substituta a pessoa que revele, por qualquer modo, incompatibilidade com a natureza da medida ou não ofereça ambiente familiar adequado" e 43, "A adoção será deferida quando apresentar reais vantagens para o adotando e fundar-se em motivos legítimos", ambos do ECA, não sendo, portanto, apenas uma peça burocrática. Assim sendo, respeitar e aplicar o cadastro de adotantes é prática cogente. No entanto, vêlo como algo absoluto seria extremamente radical nos casos em que os interesses do adotando não estiverem sendo observados. De que adiantaria respeitar o cadastro e contrariar todo um sistema que foi criado para o seu fim maior que é atender o interesse de colocação da criança e do adolescente em família substituta? Neste aspecto de fundamental discussão, necessário citar as palavras de Maria Berenice Dias e seu entendimento de que desconsiderar as peculiaridades do caso concreto não servem ao correto atendimento do instituto da adoção como um todo.

Existe uma exacerbada tendência de sacralizar a lista de preferência e não admitir, em hipótese nenhuma, a adoção por pessoas não inscritas. É tal a intransigência e a cega obediência à ordem de preferência que se deixa de atender a situações em que, mais do que necessário, é recomendável deferir a adoção sem atentar à listagem. ${ }^{47}$

Tanto é que os cadastros de adoção não são absolutos, assim como a ordem cronológica das habilitações, que o artigo 197-E, § $1^{\circ}$ do Estatuto traz as três hipóteses de desconsideração do cadastro de adotantes, repetidas no $\S 13^{\circ}$ do artigo 50 do ECA, de útil transcrição,

Somente poderá ser deferida adoção em favor de candidato domiciliado no Brasil não cadastrado previamente nos termos desta Lei quando: I - se tratar de pedido de adoção unilateral; II - for formulada por parente com o qual a criança ou adolescente mantenha vínculos de afinidade e afetividade;III - oriundo o pedido de quem detém a tutela ou guarda legal de criança maior de 3 (três) anos ou adolescente, desde que o lapso de tempo de convivência comprove a fixação de laços de afinidade e afetividade, e não seja constatada a ocorrência de má-fé ou qualquer das situações previstas nos arts. 237 ou 238 desta Lei.

\footnotetext{
${ }^{47}$ DIAS, Maria Berenice. Manual de Direito das Famílias. Ed. Revista dos Tribunais. $7^{\mathrm{a}}$ ed. 2010. p. 486.
} 
Nesses casos, a não observância do cadastro é legítima e válida, sendo fundamental ao atendimento dos interesses da criança ou do adolescente. Seguindo esta tendência, o Conselho de Supervisão da Infância e da Juventude (CONSIJ) criou orientações através do Manual de procedimentos para adoção e reconheceu, no seu artigo $5^{\circ}$, in verbis, a obrigatoriedade da observação do cadastro, ao mesmo tempo em que admitiu que existem exceções:

A adoção será deferida às pessoas previamente habilitadas para adoção, salvo na inexistência de interessados habilitados ou em casos excepcionais, como na existência de vínculo afetivo já constituído entre adotantes e adotado ou já estando a criança ou adolescente em companhia dos adotantes por tempo suficiente a se poder avaliar a conveniência da constituição do vínculo. ${ }^{48}$

Sobre a flexibilização da habilitação, faz-se necessário verificar de que forma nossos tribunais têm decidido sobre o tema. Assim sendo, nos trechos de julgados a seguir destacados verificamos que o que sempre se pretende é resguardar os interesses e direitos do adotandos, sendo fundamental o exame das peculiaridades de cada um dos casos concretos. A questão não gera muita divergência. Se assim procedermos, entenderemos que as regras sobre habilitação e cadastro não podem e não devem ser absolutas sob pena de se esvaziar o instituto da adoção tal como fora pensado e sistematizado no nosso ordenamento.

A primeira ementa, a seguir transcrita, traz situação em que os agravantes alegam possuírem condições de cuidar da criança que lhes foi entregue pela própria genitora, tendo ela anuído sobre a adoção. Dada a anuência da mãe biológica, os agravantes pleitearam a guarda para fins de adoção. O pedido de guarda provisória foi indeferido pelo juízo a quo, que entendeu não terem sido suficientemente esclarecidas as circunstâncias de entrega da menor desde o seu nascimento, e que ainda havia, paralelamente, procedimento investigativo acerca de notícia de negociação da criança entre os agravantes e a genitora. Outros motivos também deram causa ao

\footnotetext{
48 Manual de procedimentos para adoção do CONSIJ. Disponível em: <http://www.mprs.mp.br/infancia/legislacao/id2193.htm>. Acesso em 28/09/13.
} 
indeferimento do pedido de guarda: não terem os requerentes se cadastrado junto ao Juízo da Infância e Juventude, além de não terem qualquer vinculação com a família da criança. O procedimento em análise foi entendido como burla à previsão legal. Não há, portanto, situação fática que justifique excepcionar a regra geral disposta no artigo 50 do ECA. Na segunda ementa, que também segue abaixo, repete-se a ausência de vínculos e, por isso, não se justifica não obedecer a ordem do cadastro, a saber:

TJSP - Agravo de Instrumento $\mathrm{n}^{\circ}$ 162.169-0/3-00 - Acórdão AGRAVO DE INSTRUMENTO — Destituição do poder familiar e adoção Indeferimento de pedido de guarda provisória pelo casal adotante - Cabimento - Criança entregue ao casal, na saída da maternidade - Tentativa de burla ao procedimento legal - Inocorrência, outrossim, de situação a justificar a adoção "intuitu personae" - Ausência de vinculação anterior entre a mãe biológica e os requerentes - Guarda de fato por poucos meses e idade da criança a permitir vinculação a família regularmente cadastrada - Criança já entregue a casal cadastrado - Não provimento do recurso.

TJRS - Apelação Cível $\mathrm{n}^{\circ} 70030081681-$ Acórdão PEDIDO DE GUARDA PROVISÓRIA E ADOÇÃO. CRIANÇA QUE SE ENCONTRA ABRIGADA EM PROCESSO DE DESTITUIÇÃO DO PODER FAMILIAR. OBSERVÂNCIA DO PROCEDIMENTO REGULAR. PRÉVIA INSCRIÇÃO NO CADASTRO PRÓPRIO. 1. O processo de adoção deve observar a forma legal e a escolha de uma criança para adotar feita pelos pretendentes não os habilita necessariamente ao processo de adoção. 2. A existência de vínculos sólidos com o infante, que seria situação excepcional, não se verifica no caso em exame, sendo necessário antes verificar o rol de pretendentes habilitados na Comarca, cuja ordem deve ser obedecida. 3. Mesmo que o casal pretendente esteja habilitado na Comarca, isso não os habilita a escolher uma criança. 4. Deve-se atentar exclusivamente para o interesse do infante e não para o interesse das pessoas que são postulantes da adoção, mormente quando o infante ainda se encontra em processo de destituição do poder familiar dos pais biológicos e estes não consentem com a adoção. Recurso desprovido.

Situação diversa foi a enfrentada no agravo de instrumento $\mathrm{n}^{\circ}$ 1.0702.08.502543-6, TJMG, com ementa a seguir trazida à baila, que novamente excepciona a regra geral de prévia inscrição no cadastro de adoção como requisito necessário ao deferimento do pedido de adoção. O recurso pretendeu atacar a sentença proferida e que julgou extinta a ação de adoção pela ausência de formalidade essencial de prévio cadastramento da apelante na lista de adotantes do Juízo. Contudo, quando do julgamento do referido agravo de instrumento, foi reconhecido o caráter salutar do 
cadastramento, mas as circunstâncias relevantes do caso concreto conduziram à relativização do preceito contido no artigo 50 do ECA por força do estabelecimento de laços de afetividade em ementa a seguir transcrita:

TJMG - Agravo de Instrumento $\mathrm{n}^{\circ}$ 1.0702.08.502543-6 - Acórdão APELAÇÃO CÍVEL. ADOÇÃO DE MENOR. ART. 50 DO ESTATUTO DA CRIANÇA E DO ADOLESCENTE. HABILITAÇÃO E INSCRIÇÃO NO CADASTRO JUDICIAL. RELATIVIZAÇÃO DA NORMA.Nos termos do artigo 50 do Estatuto da Criança e do Adolescente, a medida de colocação em família substituta, através da ADOÇÃO, deve ser precedida da necessária habilitação e inscrição do interessado no CADASTRO do Juízo. Havendo, contudo, circunstâncias no caso concreto que justifiquem a mitigação do preceito legal, deve ser processada a ação de ADOÇÃO, ainda que ausente o prévio cadastramento.Recurso conhecido e provido.

Nesta mesma linha, foi decidido o agravo de instrumento $\mathrm{n}^{\mathrm{o}}$ 2011.094155-9, ora em comento, que trata da pretensão de guarda provisória por parte dos padrinhos da criança acolhida em seu lar desde o nascimento, com nítida e inequívoca intenção de futura adoção. A decisão de primeira instância deixa claro que não se pode incorrer no equívoco de interpretar o mandamento legal, artigo 50 do ECA, em evidente desfavor do menor, ameaçando, inclusive, a priorização de seus interesses e a tutela de sua especial dignidade. Configurada a integração da criança em família socioafetiva, há que se defender a guarda e/ou adoção com base nesta parentalidade conquistada:

TJSC - Agravo de Instrumento $\mathrm{n}^{\circ}$ 2011.094155-9 - Acórdão Agravo de Instrumento - Decisão que indefere o pedido de guarda provisória de infante, sob o fundamento de tentativa de burla ao cadastro de Adoção Insurgência - Padrinhos que criam a menor desde o nascimento como se filha fosse - Vínculo socioafetivo - Inteligência do Art. 50, II, da Lei 8.069/90 Princípios da Dignidade da Pessoa Humana e do Melhor Interesse da Criança e do Adolescente - Criança que possui uma frágil condição de saúde, tendo adoecido gravemente nos poucos dias em que permaneceu afastada da sua família afetiva - Deferimento da guarda em favor dos padrinhos que se impõe - Recurso Conhecido e Provido

Portanto, o que deve ser combatido é a entrega de crianças a terceiros com quem não tenham efetivo vínculo, a chamada entrega direta, quer na forma de adoção irregular, na qual o pretendente recolhe a criança ao seu convívio e depois de determinado tempo ingressa com pedido de adoção, 
quer como adoção à brasileira, situação em que alguém procede ao registro do nascimento de uma criança como se genitor biológico fosse. Em ambos os casos estaria a criança ou o adolescente em situação de risco, já que não teria ocorrido o exame prévio das efetivas condições sociais, psíquicas, etc de seu(s) adotante(s), ou seja, condições e critérios que precisam ser observados como etapas de um fim, fim este que tem na adoção, na entrega do adotado, o seu último ato, o que a faz estar revestida de segurança.

Nestas duas hipóteses, adoção irregular e adoção à brasileira, não há como compatibilizá-las às exceções trazidas pela lei, o que as difere, em muito, da adoção intuitu personae, objeto deste trabalho, que aqui procuraremos defender no capítulo seguinte. Urge passarmos à conceituação desta modalidade de adoção e à necessidade de análise de casos concretos para que possamos entender a flexibilização das regras de habilitação e cadastro de adotantes impostas pelo Estatuto da Criança e do Adolescente e pela Lei de Adoção. 


\section{CAPÍTULO 3. ADOÇÃO INTUITU PERSONAE}

\subsection{Conceito}

A adoção intuitu personae é tema pouquíssimo abordado pela nossa doutrina. Surge, então, o desafio de falar sobre o tema, trazer aqueles que discorrem sobre o assunto e avaliar a forma como nossos tribunais têm decidido em relação a esta modalidade de adoção. Julio César Gomes esclarece que o tema "sempre foi visto como empecilho a plena aplicabilidade do instituto da Adoção, recorridas vezes qualificado como um subterfúgio utilizado pelos interessados em adotar e tantas outras vezes como uma afronta à legislação. "49

Primeiramente, objetivando um completo entendimento deste instituto, faz-se necessária a apresentação dos conceitos trazidos por estudiosos do direito. Dessa forma, temos:

Chama-se de adoção intuitu personae quando há o desejo da mãe de entregar o filho a determinada pessoa. Também é assim chamada a determinação de alguém em adotar uma certa criança. As circunstâncias são variadas. ${ }^{50}$

Em regra, esta adoção ocorre quando uma mulher que irá dar à luz revela a pessoas conhecidas que não tem condições de criar e educar o filho, e que pretende dá-lo a quem tiver mais condições. Por interpostas pessoas ou diretamente, um casal manifesta o desejo de adotar, e não raro passa a dar assistência para que aquele parto seja bem sucedido. Nascida a criança, a mãe a entrega ao casal adotante que, após exercer a guarda de fato por determinado período, ajuíza ação de adoção com o consentimento expresso da genitora, pleiteando antecipação de tutela para obtenção da guarda provisória. ${ }^{51}$

É a adoção em que a mãe biológica determina para quem deseja entregar o seu filho. $\mathrm{O}$ ato de definir a quem entregar o filho é chamado de "intuito personae". $\mathrm{Na}$ maioria dos casos, a mãe procura a Vara da Infância e da Juventude

\footnotetext{
${ }^{49}$ GOMES, Júlio César. Adoção intuitu personae e o princípio do melhor interesse do menor. Disponível em: http://www.juristas.com.br/informacao/artigos/adocao-intuitu-personae-e-oprincipio-do-melhor-interesse-do-menor/882/. Acesso em 18/10/2013.
}

\footnotetext{
${ }^{50}$ DIAS, Maria Berenice. Manual de Direito das Famílias. $7^{\mathrm{a}}$ ed. Ed. Revista dos Tribunais, pp. 486-487.

${ }^{51}$ SOUZA, Rodrigo F. de, Juiz de Direito da $2^{\text {a }}$ Vara de Família, Infância, Juventude e Idoso da Comarca de Nilópolis - RJ - Revista da EMERJ, v. 12, nº 45, 2009, p. 184.
} 
acompanhada do pretendente à adoção para legalizar uma convivência que já esteja acontecendo de fato. É um tema bastante polêmico. ${ }^{52}$

A adoção intuitu personae é a conhecida adoção consensual onde a família biológica, comumente apenas a mãe, eis que desconhecido ou ausente o pai, entrega a criança em adoção a pessoa conhecida. ${ }^{53}$

Da doutrina supracitada extraímos que a adoção intuitu personae é a modalidade de adoção que consiste na entrega dirigida, ou seja, a pessoa(s) específica(s). Daí este tipo de adoção também ser conhecido como adoção dirigida. Nela tem-se a chamada filiação socioafetiva e a paternidade socioafetiva. Nas palavras de Luiz Fernando Valladão,

A notória revolução ocorrida no âmbito da família brasileira revela mudanças conceituais, sendo uma delas a criação das relações socioafetivas. Essas são as que envolvem pessoas sem qualquer parentesco sanguíneo, como a relação entre filhos e pais de criação ou, de maneira figurada, de coração. Trata-se da relação baseada no afeto e não apenas na origem biológica, a chamada paternidade socioafetiva. Apesar de a paternidade socioafetiva não estar expressamente prevista em nossa legislação atual, não existem dúvidas de que ela está assegurada constitucionalmente na Carta Magna. Nela, está registrado que "os filhos, havidos ou não da relação do casamento, ou por adoção, terão os mesmos direitos e qualificações, proibidas quaisquer designações discriminatórias relativas à filiação". Além disso, segundo o Código Civil, "o parentesco é natural ou civil, conforme resulte de consanguinidade ou outra origem ${ }^{54}$.

\section{Assim sendo,}

[...] onde o objeto de tutela é a pessoa, a perspectiva deve mudar; torna-se necessidade lógica reconhecer, pela especial natureza do interesse protegido, que é justamente a pessoa a constituir ao mesmo tempo o sujeito titular do direito e o ponto de referência objetivo da relação. $\mathrm{O}$ "ser", muito mais importante que o "ter" na escala de valores, é prestigiado pelo ordenamento jurídico, sobretudo no que respeita a preservação da dignidade humana. ${ }^{55}$

Boa parte da doutrina se filia à tese de Cristiano Chaves de Farias e Nelson Rosenvald, segundo a qual a prova da filiação decorrente de

\footnotetext{
52 Disponível em: http://www.amb.com.br/mudeumdestino/docs/Manual\%20de\%20adocao.pdf. Acesso em 03/10/2013.

${ }^{53}$ MOREIRA, Silvana do Monte. A adoção intuitu personae e a necessária habilitação prévia. Disponível em: http://silvanammadv.blogspot.com.br/2012/02/adocao-intuitu-personae-enecessaria.html. Acesso em 18/10/2013.

54 VALLADÃO, Luiz Fernando. Paternidade socioafetiva. Fonte: http://www.ibdfam.org.br/artigos/811/Paternidade+socioafetiva. Acesso em 09/10/2013.

${ }^{55}$ PERLINGIERI, Pietro. Perfis do direito civil - introdução ao direito civil constitucional. $3^{\mathrm{a}}$. ed.. São Paulo: Renovar, 2007. p. 155.
} 
tratamento afetivo entre as pessoas é a "projeção da teoria da aparência sobre as relações jurídicas filiatórias, estabelecendo uma situação fática que merece tratamento jurídico ${ }^{56 "}$. José Bernardo Ramos Boeira explica a posse de estado sob o prisma da teoria da aparência:

(...) a juízo de terceiros, o detentor da "posse de estado de filho" passa a desfrutar de uma situação que, efetivamente, não existe, em termos de formalização, mas a aceitação é de tal ordem determinada pela aparência que, o que importa no caso, é a publicidade resultante desta situação de fato. (...) Na verdade, a parência revela a "posse de estado" em toda sua amplitude, demonstrado a relação paterno-filial em todos os seus elementos identificadores, revelando a terceiros o que até então era desconhecido. (...) Por isso, na "posse de estado", sempre haverá de coincidir a verdade exterior (objetiva), ditada pela verdade dos fatos, com a verdade interior (subjetiva), produto do sentimento, refletido pela relação paterno-filial. ${ }^{57}$

Das definições aqui apresentadas, cumpre ressaltar que o tipo de adoção objeto deste estudo tem um aspecto a mais em relação à adoção convencional. Nesta última, há o consentimento dos pais, mas não há a escolha dos mesmos sobre aqueles que serão os novos detentores do poder familiar. A escolha é, portanto, o elemento central da adoção intuitu personae ou adoção dirigida e dela decorre afeto, vínculos de afetividade, aspectos de importância fundamental na análise de qualquer caso que envolva esta forma de adoção. Há também o que muitos alegam como “desrespeito à fila do cadastro", de que a vedação à inobservância do cadastro está implícita no artigo 50 do Estatuto da Criança e do Adolescente. São, nesta linha, argumentos cegos, sendo necessário derrubar o preconceito daqueles que, de saída, apontam à ilegalidade da adoção intuitu personae. Esta tese ultrapassada não merece prosperar.

$\mathrm{Na}$ adoção dirigida não há conduta criminosa, uma vez que a integridade física e a vida da criança não são expostas ao perigo. Não há, tecnicamente, abandono, mas sim a entrega do menor a um terceiro que os pais acreditam ser capaz de cuidar mais adequadamente do menor e lhe oferecer condições superiores a ele. ${ }^{58}$

\footnotetext{
${ }^{56}$ FARIAS, Cristiano Chaves de; ROSENVALD, Nelson. Direito da Famílias. 2 ${ }^{\mathrm{a}}$ ed. Rio de Janeiro: Lumen Juris, 2010. pp. 547-548.

57 BOEIRA, José Bernardo Ramos. Investigação de paternidade: posse de estado de filho:paternidade socioafetiva. Porto Alegre: Livraria do Advogado, 1999. pp. 81-83.

${ }^{58}$ SOUZA, Rodrigo F. de, Juiz de Direito da $2^{\text {a }}$ Vara de Família, Infância, Juventude e Idoso da Comarca de Nilópolis - RJ - Revista da EMERJ, v. 12, no 45, 2009. p. 184.
} 
Apesar disso, ao menos no Tribunal de Justiça Grande do Sul prevalece o entendimento segundo o qual a adoção dirigida não deve ser acolhida, em regra, e que deve prevalecer, pelo menos em um primeiro momento, a ordem do cadastro de adotantes. Tanto é que no $1^{\circ}$ Encontro dos Juízes da Infância e da Juventude do Tribunal de Justiça do Rio Grande do Sul os magistrados aprovaram por unanimidade o Enunciado $10 \mathrm{com}$ a seguinte redação:

Em que pese não ser a priori ilegal, a adoção dirigida não é recomendável, devendo-se adotar cautelas quanto à legitimidade do consentimento materno, bem como promover, como regra, a observância do Cadastro de Pretendentes à adoção, inclusive advertindo e responsabilizando entidades e pessoas que promovam o agenciamento de crianças para adoção. ${ }^{59}$

No entanto, no resto do país, tal assunto recebe outro tratamento, sendo reconhecida a possibilidade e a legalidade da adoção intuitu personae em razão das peculiaridades de cada um dos casos concretos. Esta é tendência que se observa na nossa jurisprudência.

\subsection{Adoção intuitu personae e adoção à brasileira}

Muitas pessoas costumam confundir adoção à brasileira com adoção intuitu personae, sendo necessário, portanto, diferenciá-las. A expressão "adoção à brasileira" é utilizada para designar um fenômeno muito comum no Brasil: "o fato de uma pessoa registrar filho alheio como próprio ${ }^{60}$ ". Sendo assim, Eunice Granato esclarece que:

Esse registro, feito no Cartório de Registro Civil das Pessoas Naturais, é extremamente fácil, já que basta o suposto pai ou mãe ali comparecer e declarar o nascimento, obedecendo ao disposto no artigo 54 da Lei de Registros Públicos (Lei 6.015, de 31.12.1973) ${ }^{61}$.

59

Disponível

em:

http://www.tjrs.jus.br/site/poder_judiciario/tribunal_de_justica/corregedoria_geral_da_justica/acoe s/encontros_de execucao_penal/encontros_de_juizes_da_infancia_e_juventude/conclusoes_lenco ntro_infancia.html. Acesso em 20/10/2013.

${ }^{60}$ FARIAS, Cristiano Chaves de; ROSEnVALD, Nelson. Direito da Famílias. $2^{\mathrm{a}}$ Ed.. Rio de Janeiro: Lumen Juris, 2010. p. 927.

${ }^{61}$ GRANATO, Eunice. Adoção doutrina e prática. Ed. Juruá, 2009. pp.130-131. 
Vem recebendo esta denominação pela doutrina e pela jurisprudência pelo fato de configurar a paternidade socioafetiva, cujo grande exemplo é a adoção convencional e a ela se assemelha neste ponto ${ }^{62}$.

Sobre a anulação desse registro, a doutrina diverge. Nas palavras de Galdino Bordallo, "por conter uma declaração falsa, vício intrínseco, o registro é nulo, passível de desconstituição a qualquer tempo." 63 . No entanto, Maria Berenice Dias traz nova visão, também alinhada a nossa jurisprudência:

a jurisprudência, reconhecendo a voluntariedade do ato, praticado de modo espontâneo, por meio da "adoção à brasileira", passou a não admitir a anulação do registro de nascimento, considerando irreversível. Não tendo havido vício de vontade, não cabe a anulação, sob o fundamento de que a lei não autorizava a ninguém vindicar estado contrário ao que resulta do registro de nascimento (CC 1.604). Ainda que dito dispositivo legal excepcione a possibilidade de anulação por erro ou falsidade, não se pode aceitar a alegação de falsidade do registro levada a efeito pelo autor do delito. Assim, registrar filho alheio como próprio, sabendo não ser verdadeira filiação, impede posterior pedido de anulação. $O$ registro não revela mais do que aquilo que foi declarado - por conseguinte, corresponde à realidade do fato jurídico. Descabido falar em falsidade. ${ }^{64}$

Dessa forma, a tendência é reconhecer o caráter irrevogável da adoção "à brasileira", ainda que muitos a considerem como ilegal, crime contra o estado de filiação disposto no artigo 242 do Código Penal - “(...) registrar como seu o filho de outrem; (...)" -, inserido no Capítulo III, "Dos crimes contra a assistência familiar". Irrevogabilidade que se justifica através do princípio do melhor interesse da criança e do adolescente, já que, uma vez adequado em família substituta, imprudente retirar o adotado da mesma, sob pena de lhe causar enormes transtornos psicológicos e emocionais. "Imperativo prestigiar a posse de estado de filho de que desfruta o registrado, na medida em que se configurou a filiação

\footnotetext{
${ }^{62}$ BORDALLO, Galdino Augusto Coelho. Em Curso de direito da criança e do adolescente: aspectos teóricos e práticos. $4^{\mathrm{a}}$ ed.. Rio de Janeiro: Ed. Lumen Júris, 2010. p. 255.

${ }^{63}$ Ibid. p. 256.

${ }^{64}$ DIAS, Maria Berenice. Manual de Direito das Famílias. $7^{\mathrm{a}}$ ed. Ed. revista dos tribunais, pp. 485-486.
} 
socioafetiva. ${ }^{65 "}$ Neste diapasão, Cristiano Chaves de Farias e Nelson Rosenvald comentam que "Maria Berenice Dias consagra o afeto como verdadeiro direito fundamental, permitindo projeções do mais alto relevo, como, v.g., o reconhecimento da igualdade entre a filiação biológica e a filiação socioafetiva ${ }^{66 "}$. No mesmo sentido, sustenta Rolf Madaleno:

Não há, realmente, como distinguir um ato de adoção jurídica da denominada adoção à brasileira, consistente no registro direto da pessoa, como se fosse filho biológico, posto que uma e outra refletem um desejo de aproximação afetiva entre duas pessoas, e neste posicionamento o filho adotivo (de fato ou de direito) em nada diverge da filiação natural. ${ }^{67}$

O reconhecimento da adoção à brasileira quando da constatação de filiação socioafetiva/parentalidade socioafetiva vem sendo acolhido por nossos tribunais. E também está é a posição do STJ, sendo oportuna a transcrição de trecho do Recurso Especial 1000356/SP, de relatoria da Ministra Nancy Andrighy, julgado em 25/05/2010:

Conquanto a adoção à brasileira não se revista da validade própria daquela realizada nos moldes legais, escapando à disciplina estabelecida nos arts. 39 usque 52-D e 165 usque 170 do ECA, há de preponderar-se em hipóteses como a julgada, consideradas as especificidades de cada caso, a preservação da estabilidade familiar, em situação consolidada e amplamente reconhecida no meio social, sem identificação de vício de consentimento ou de má-fé, em que, movida pelos mais nobres sentimentos de humanidade, A. F. V. manifestou a verdadeira intenção de acolher como filha C. F. V., destinando-lhe afeto e cuidados inerentes à maternidade construída e plenamente exercida (...) prevalece, na hipótese, a ligação socioafetiva construída e consolidada entre mãe e filha, que tem proteção indelével conferida à personalidade humana, por meio da cláusula geral que a tutela e encontra respaldo na preservação da estabilidade familiar. ${ }^{68}$

\footnotetext{
${ }^{65}$ DIAS, Maria Berenice. Manual de Direito das Famílias. $7^{\mathrm{a}}$ ed. Ed. revista dos tribunais, p.486.

${ }^{66}$ FARIAS, Cristiano Chaves de; ROSENVALD, Nelson. Direito das Famílias. 2 ${ }^{\mathrm{a}}$ ed.. Rio de Janeiro: Lumen Juris, 2010. p. 25.

${ }^{67}$ MADALENO, Rolf. Curso de Direito de Família. 2a edição. Rio de Janeiro: Forense, 2008. p. 493.

68 Disponível em: http://stj.jusbrasil.com.br/jurisprudencia/14318607/recurso-especial-resp1000356-sp-2007-0252697-5/inteiro-teor-14318608. Acesso em 15/10/2013.
} 


\subsection{Da divergência na doutrina quanto à legalidade da adoção intuitu personae}

O debate na doutrina acerca da legalidade da adoção intuitu personae repousa sobre alguns aspectos, dentre os quais podemos citar a possibilidade ou não da disposição do poder familiar, certa forma de disposição assim dita quando referente à escolha, o atendimento do requisito do estágio de convivência para que a adoção seja deferida, o cego e frio respeito ao cadastro que tem como pressuposto a habilitação do adotante. Como bem salienta o Juiz de Direito Rodrigo Faria de Souza,

preambularmente, faz-se mister reconhecer que tal conduta não é ilegal, uma vez que não há qualquer norma, seja constitucional ou infraconstitucional, que vede expressamente tal comportamento. (...) Há de se avaliar se a adoção dirigida observa o princípio do melhor interesse da criança, consagrado em nossa Constituição no artigo 227 e corroborado pelo Estatuto da Criança e do Adolescente (Lei 8.069/90). ${ }^{69}$

Sistematizando tais desdobramentos, um panorama geral sobre o tema é delineado por Cristiane Dupret:

(...) Sustentando-se a possibilidade da adoção intuitu personae, porém, é fundamental que se estabeleçam alguns critérios para a adoção direcionada, visando, sobretudo, prevalecer o vínculo de afeto existente entre adotante e adotado, a fim de que esta modalidade de adoção não represente uma "troca de interesses". Apesar desta modalidade, claramente, priorizar o melhor interesse do adotado, inutiliza a regra do art. 50 do ECA (Cadastro Nacional de Adotantes), o que faz parte da doutrina defender o não uso da adoção intuitu personae "pelos riscos de comércio ou intermediação indevida, com exploração decorrente, o desrespeito ao direito fundamental da criança de ser criada em sua família natural ou ampliada, e a manifesta burla ao cadastro de pretendentes à adoção. Porém, é preciso reconhecer que o excesso de burocratização no processo de adoção, recentemente atualizado pela Lei 12.010/10, beneficia este tipo de adoção $(. . .)^{70}$.

Sobre tal polêmica, Júlio César Gomes esclarece que a ausência de uma legislação que corrobore a possibilidade deste tipo de adoção, já que o ECA não é expresso quanto ao tema, ao lado da exacerbada burocracia, emergem como verdadeiros entraves à aplicação do princípio do melhor

\footnotetext{
${ }^{69}$ SOUZA, Rodrigo F. de, Juiz de Direito da $2^{\mathrm{a}}$ Vara de Família, Infância, Juventude e Idoso da Comarca de Nilópolis - RJ - Revista da EMERJ, v. 12, nº 45, 2009, p. 185.

70 DUPRET, Cristiane. Direito da Criança $e$ do Adolescente. Disponível em: http://canalconselhotutelar.files.wordpress.com/2012/01/329 apostila_de eca.pdf. Acesso em 18/10/2013.
} 
interesse da criança e do adolescente e ao reconhecimento da legalidade da adoção intuitu personae. E vai além, ao apontar que tal posicionamento também é seguido por Maria Berenice Dias:

Maria Berenice Dias, consagrada por seus posicionamentos mais avançados, demonstra uma notória crítica ao legislador, que deixou de classificar a referida modalidade de adoção no Estatuto da Criança e do Adolescente, criando assim uma insegurança para aqueles que pretender pleitear o deferimento da medida ante ao Judiciário ${ }^{71}$.

Objetivando a não aceitação da legalidade da adoção intuitu personae, muitos têm alegado o suposto conflito relacionado à interpretação literal do ECA no $§ 13$ do artigo 50 - "Somente poderá ser deferida adoção em favor de candidato domiciliado no Brasil não cadastrado (...)” - em consonância com o artigo 166 - "Se os pais forem falecidos, tiverem sido destituídos ou suspensos do poder familiar, ou houverem aderido expressamente ao pedido de colocação em família substituta, este poderá ser formulado diretamente em cartório, em petição assinada pelos próprios requerentes, dispensada a assistência de advogado”. Dessa forma, a teor do que dispõe o referido parágrafo do artigo 50 estaria o artigo 166 revogado. Sobre tal entendimento,

(...) entendemos, contudo, assim como vários outros operadores do direito, que se o legislador tivesse a intenção de revogar tal artigo o teria feito e não o manteria na mesma lei. Não se trata de erro material, o artigo 166 subsiste e é claro no que determina, através da inclusão, pela própria Lei $\mathrm{n}^{\circ}$ 12.010/2009, dos parágrafos de $1^{\circ}$ ao $7^{\circ}$, vez que o objetivo dos parágrafos, de conformidade com a hermenêutica jurídica, é o de dar especificidade à matéria de que trata o caput. ${ }^{72}$

Iniciaremos a discussão dos elementos ligados à adoção dirigida analisando os desdobramentos relativos ao poder familiar, já aqui conceituado e analisado no item 1.6, "A adoção e o poder familiar".

\footnotetext{
${ }^{71}$ GOMES, Júlio César. Adoção intuitu personae e o princípio do melhor interesse do menor. Disponível em: http://www.juristas.com.br/informacao/artigos/adocao-intuitu-personae-e-oprincipio-do-melhor-interesse-do-menor/882/. Acesso em 18/10/2013.

72 Disponível em: http://www.arrudaeadvogados.adv.br/downloads/adocaointuitopersonae.pdf. Acesso em 20/10/2013.
} 


\subsubsection{O poder familiar e o elemento escolha na adoção dirigida:}

Conforme analisado no item 1.6, a adoção pressupõe a extinção do poder familiar. $\mathrm{Na}$ adoção intuitu personae, os pais biológicos, ou aquele(s) que detenha(m) o poder familiar, escolhe $(\mathrm{m})$ quem serão os pais afetivos de seu filho. Neste ponto, a escolha deverá ser compreendida como um ato de disposição dos pais biológicos porque realizada quando o poder familiar é por eles ainda exercido, ou seja, "há a intervenção dos pais biológicos na escolha da família substituta, ocorrendo esta escolha em momento anterior à chegada do pedido de adoção ao conhecimento do Poder Judiciário."73 Se a escolha ocorre antes da destituição do poder familiar, podemos entendê-la como maneira de ingerência sobre este. Tendo como base a escolha, cumpre, neste momento, analisar as seguintes questões: pode o(a) genitor(a) dispor do poder familiar? Como objetivar a escolha feita por este(s)? Na doutrina e na jurisprudência, encontramos resposta para estes questionamentos.

Não vemos nenhum problema nessa possibilidade, eis que são os detentores do poder familiar e possuem todo o direito de zelarem pelo bem-estar de seu rebento. Temos que deixar de encarar os pais que optam por entregar seu filho em adoção como pessoas que cometem alguma espécie de crime. A ação desses pais merece compreensão, pois se verificam que não terão condições de cuidar da criança, ao optarem pela entrega, estão agindo com todo o amor e carinho por seu filho, buscando aquilo que entendem melhor para ele. Assim, se escolhem pessoas para assumir a paternidade de seu filho, deve-se respeitar esta escolha. ${ }^{74}$

A ordem cronológica do artigo 50 do Estatuto, comporta flexibilidade, quando dois casais, em igualdade de condições, disputam a adoção de menor, especialmente em caso de chamada "adoção dirigida", em que a mãe escolhe os adotantes desde já, entregando-lhes o filho, confiada na melhor guarda e no futuro da criança, que pretende proteger, para que tenha um futuro garantido, e não venha a sofrer como ela as vicissitudes da vida (...) quer proteger a sua cria e nada impede que assim o faça.(TJRS - AI 598023919 - RS - 8 Câmara Cível Relator Des. Roque Miguel Fank - Julgamento em 26/03/1998).

Tendo a genitora da menor entregue sua filha em adoção a um casal determinado (adoção intuitu personae), não se pode desconsiderar tal vontade, em razão da existência de listagem de casais cadastrados para adotar. A lista serve para organizar a ordem de preferência na adoção de crianças e adolescentes, não

\footnotetext{
${ }_{73}$ BORDALLO, Galdino Augusto Coelho. Em Curso de direito da criança e do adolescente: aspectos teóricos e práticos. $4^{\mathrm{a}}$ ed.. Rio de Janeiro: Editora Lumen Júris, 2010. p. 251.

${ }^{74}$ Ibid., p. 252.
} 
podendo ser mais importante que o ato de adoção em si. (TJRS AC70006597223 - RS - 7 Câmara Cível - Relator Des. Luiz Felipe Brasil Santos - Julgamento em 13/08/2003).

E Madaleno acrescenta que todo esse processo de escolha ocorre comumente sem a intervenção do Poder Judiciário, na constância do poder familiar exercido pelos genitores, de forma que "essa aproximação entre os pais biológicos e os adotantes já vinha sucedendo, provavelmente, durante todo o período de gestação ${ }^{75}$ ". É um argumento plausível e razoável a dar ensejo à possibilidade de escolha pelos titulares do poder familiar. Escolha que se faz justificada pelo afeto.

Ainda sobre este aspecto é relevante que se perceba as situações as quais a suposta entrega pode significar a prática do tráfico de crianças, crime tipificado no artigo 328 do Código Penal. Este é um risco que não pode ser desprezado. Dessa forma, nossa jurisprudência vem entendendo que a escolha feita pelos pais biológicos em relação aos pais adotivos de seu filho é possível se realizada em consonância com os interesses do $\operatorname{adotando}^{76}$. Admite-se a adoção intuitu personae em função do peso maior dado ao afeto e ao estabelecimento de vínculos que atendem o foco do interesse em adoção, interesse este que precisa ser o do adotando, sob pena de se frustrar os princípios fundamentais da criança e do adolescente, tão fortemente preconizado em nosso ordenamento.

Dar filho à adoção é o maior gesto de amor que existe: sabendo que não poderá criá-lo, renunciar ao filho, para assegurar-lhe uma vida melhor da que pode lhe propiciar, é atitude que só o amor justifica. E nada, absolutamente nada impede que a mãe escolha quem sejam os pais de seu filho. Às vezes é a patroa, às vezes uma vizinha, em outros casos um casal de amigos que têm uma maneira de ver a vida, uma retidão de caráter que a mãe acha que seriam os pais ideais para o seu filho. É o que se chama de adoção intuitu personae, que não está prevista na lei, mas também não é vedada. A omissão do legislador em sede de adoção não significa que não existe tal possibilidade. Ao contrário, basta lembrar que a lei assegura aos pais o direito de nomear tutor a seu filho (CC , art. 1.729). E, se há

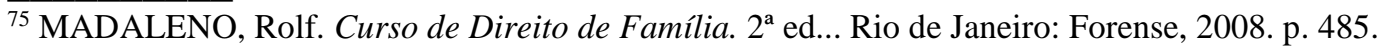

76 Basta ver o Enunciado 385 da Terceira Turma do STJ. Disponível em http://www.stj.jus.br/SCON/infojur/doc.jsp?livre=@ cod=0385, “ADOÇÃO. VÍNCULO. CRIANÇA. ADOTANTE", acesso em 15/10/2013, segundo o qual o julgamento em 5/3/2009 do AgRg na MC 15.097-MG, Rel. Min. Massami Uyeda, reconheceu como legítima a adoção intuitu personae no caso em comento, que será posteriormente analisado.
} 
a possibilidade de eleger quem vai ficar com o filho depois da morte, não se justifica negar o direito de escolha a quem dar em adoção. ${ }^{77}$

\subsection{2. $O$ atendimento ao estágio de convivência na adoção intuitu personae}

O estágio de convivência, também já aqui apresentado no capítulo 1, está disciplinado no artigo 46 do ECA, - "A adoção será precedida de estágio de convivência com a criança ou adolescente, pelo prazo que a autoridade judiciária fixar, observadas as peculiaridades do caso."-. Da leitura deste dispositivo, compreendemos que não há qualquer menção ou caráter taxativo ao período mínimo que será dispensado a tal estágio. Assim, fica a critério da autoridade Judiciária, com participação da equipe técnica, determinar o período mínimo necessário para que se verifique a plenitude da adaptação do adotado no seio da família substituta.

Ao mesmo tempo, também previu o legislador sobre a hipótese de dispensa do estágio de convivência nos parágrafos $1^{\circ}$ e $2^{\circ}$, do mesmo artigo 46, a seguir transcritos:

O estágio de convivência poderá ser dispensado se o adotando já estiver sob a tutela ou guarda legal do adotante durante tempo suficiente para que seja possível avaliar a conveniência da constituição do vínculo.

A simples guarda de fato não autoriza, por si só, a dispensa da realização do estágio de convivência.

Se procedermos à análise superficial destes dispositivos, observamos que o legislador teve a intenção de proteger a regularização da guarda. Nesta linha, é notória a intenção de não se permitir a procedência de pedidos de guarda e/ou adoção que tenham meios escusos como origem. Sendo o estágio de convivência ou período de convivência, como preferem alguns doutrinadores, o lapso temporal em que a nova família será acompanhada pelo Juízo responsável pelo deferimento da adoção, bem

\footnotetext{
${ }^{77}$ DIAS, Maria Berenice. Adoção $e$ a espera do amor. Disponível em: http://www.mariaberenice.com.br/uploads/1__ado\%E7\%E3o_e_a espera_do_amor.pdf. Acesso em $15 / 10 / 2013$.
} 
como pelos seus auxiliares, a fim de se verificar a adaptação entre o adotando e o adotante, como fica tal requisito na adoção intuitu personae?

Normalmente, em relação às demandas que envolvem a adoção dirigida, o que ocorre é a entrega informal, ou seja, a criança ou o adolescente passa a viver com sua nova família, de modo a atender ao requisito do estágio de convivência exigido pelo Estatuto. Entrega informal porque tal convivência não foi estabelecida e determinada sob o crivo do Poder Judiciário, o que ocorreria em consonância com o artigo supracitado. É a chamada guarda de fato. No entanto, informalidade não pode ser, de saída, compreendida como ilegalidade. Isto porque se em alguns casos estiverem presentes os demais requisitos que permitam à autoridade Judiciária dispensar o estágio de convivência (parágrafos $1^{\circ}$ e $2^{\circ}$ do artigo 46 do Estatuto, supra) não haverá empecilho para que o referido estágio não seja dispensado. Em nome do melhor interesse da criança ou do adolescente, estabelecidos vínculos de afetividade, não há que se retirá-la da família substituta, motivo pelo qual não será possível cogitar a ilegalidade da adoção intuitu personae pelo não atendimento do estágio de convivência. O lapso temporal, ainda que verificado durante o exercício de uma guarda de fato, aliado ao afeto como fruto deste convívio, justificam tal dispensa.

\subsubsection{A possibilidade do deferimento da adoção sem atender ao cadastro}

No capítulo 2, analisamos o histórico de criação dos cadastros estaduais e nacional de adoção. Do que foi anteriormente analisado, oportuno aqui voltar a frisar que os incisos do $\$ 13$ do artigo 50 do Estatuto da Criança e do Adolescente, incluídos pela Lei de Adoção, trazem a regra excepcional segundo a qual há a possibilidade da adoção ser deferida àquele que não estiver cadastrado se e somente:

I - se tratar de pedido de adoção unilateral; 
II - for formulada por parente com o qual a criança ou adolescente mantenha vínculos de afinidade e afetividade;

III - oriundo o pedido de quem detém a tutela ou guarda legal de criança maior de 3 (três) anos ou adolescente, desde que o lapso de tempo de convivência comprove a fixação de laços de afinidade e afetividade, e não seja constatada a ocorrência de má-fé ou qualquer das situações previstas nos arts. 237 ou 238 desta Lei

Do dispositivo acima transcrito, não resta dúvida de que o cadastro não é absoluto nas três hipóteses descritas, de sorte que quando um pedido de adoção dirigida se debruçar sobre umas destas exceções, estabelecidos vínculos, e em atendimento à doutrina da proteção integral da criança e do adolescente, não é razoável que tal pedido seja indeferido e que se passe a obedecer cegamente à fila do cadastro. Sobre tal aspecto, úteis são os pensamentos de Eunice Granato e, mais uma vez, de Cristiane Dupret:

Questiona-se se é justo àquele casal que ficou com o recém-nascido e que eventualmente o manteve em sua companhia por vários meses, que a ele se afeiçoou, com ele criou vínculos e que, acreditando na justiça a procurou, subitamente, o veja tomado de seus braços e talvez o perca para sempre, em nome de uma burocrática "fila"? Essa medida atenderá ao "superior interesse da criança", uma vez que esse infante sofrerá a dor da separação da família que o acolheu. $^{78}$

(...) Assim, não deve ser a inscrição na lista de adotantes uma condição sine qua non, um requisito insuperável, absoluto, para a efetivação da adoção. Deve-se, sobretudo, atentar ao direito da criança de ser adotada por quem já lhe dedica cuidado e atenção, em vez de priorizar os adultos pelo simples fato de estarem incluídos numa listagem, e só por isso. ${ }^{79}$

Em nome do melhor interesse da criança e do adolescente, conforme regra constante no artigo 28, $\S 3^{\circ}$ do ECA - "Na apreciação do pedido levar-se-á em conta o grau de parentesco e a relação de afinidade ou de afetividade, a fim de evitar ou minorar as consequências decorrentes da medida” -, cumpre esclarecer que a aparente burla à fila do cadastro não pode ser assim considerada, não sendo, portanto, um aspecto negativo da

\footnotetext{
${ }_{78}$ GRANATO, Eunice Ferreira Rodrigues. Adoção: doutrina e prática - Curitiba: Juruá, 2010, p.142.

79 DUPRET, Cristiane. Direito da Criança $e$ do Adolescente. Disponível em: http://canalconselhotutelar.files.wordpress.com/2012/01/329 apostila_de_eca.pdf. Acesso em 18/10/2013.
} 
adoção intuitu personae. Nesta mesma linha, a justificativa de que a vedação à inobservância do cadastro está implícita no artigo 50 do ECA, que traz a ordem de observância obrigatória do cadastro, também não merece prosperar. Mais uma vez, utilizando as palavras de Maria Berenice, já citada às fls. 46, trazemos o pensamento de que o cadastro é um mero organizador e facilitador, possuindo papel secundário no processo de adoção:

Existe uma exacerbada tendência de sacralizar a lista de preferência e não admitir, em hipótese nenhuma, a adoção por pessoas não inscritas. É tal a intransigência e a cega obediência à ordem de preferência que se deixa de atender a situaçõos em que, mais do que necessário, é recomendável deferir a adoção sem atentar à listagem ${ }^{80}$.

Outra situação é a enfrentada por quem mantém vínculos com a criança, uma vez que a mesma já está sob os seus cuidados, mas que ao ingressar com o pedido de guarda ou de adoção para regularizar uma guarda de fato, não está inscrito no cadastro como habilitado à adoção. Alega-se que a entrega oficial da criança poderá ser feita a pessoa despreparada.

(...) Acreditamos que o maior risco esteja, inclusive, na entrega dos filhos a pessoas não preparadas para a adoção. Essa realidade, onde pessoas não habilitadas recebem crianças diretamente da família biológica, é bastante comum, principalmente em pequenas cidades e, ao final, o Juízo, após anos de convivência e do vínculo afetivo solidificado, obriga-se a ratificar uma situação já consolidada de fato, principalmente em face dos laços da filiação sócio-afetiva. $\mathrm{Na}$ realidade, Juízo, Ministério Público e equipes técnicas do judiciário são verdadeiramente atropelados por situações de fato já consolidadas $(\ldots.){ }^{81}$

Em relação a este argumento, não pode ser este a dar ensejo, de saída, ao indeferimento de um pedido de adoção intuitu personae quando os adotantes nem mesmo encontram-se habilitados e, consequentemente, cadastrados. Pensamos ser assim coerente porque nem mesmo em relação a um adotante previamente habilitado e cadastrado é possível garantir com $100 \%$ de certeza que esta pessoa está preparada para ser pai e/ou mãe. Um

\footnotetext{
${ }_{80}^{80}$ DIAS, MARIA BERENICE. Manual de Direito das Famílias. $7^{\mathrm{a}}$ ed.. Ed. Revista dos Tribunais. 2010. p. 486.

81 Disponível em: http://www.arrudaeadvogados.adv.br/downloads/adocaointuitopersonae.pdf. Acesso em 20/10/2013.
} 
aspecto é a teoria e outro é a prática. Isto porque como bem ressalta Galdino Bordallo,

este fato será avaliado no transcorrer da instrução processual, através dos pareceres da equipe interprofissional. Concluindo o parecer pela inabilidade dos adotantes para exercer o papel de pai e mãe, deverá ser retirada a criança da guarda destes e ser buscada outra pessoa para cumprir este papel ${ }^{82}$.

Dos aspectos que foram aqui analisados, frisa-se que a adoção dirigida não pode ser tida como ilegal e não pode ser julgada improcedente sem que se avalie as peculiaridades do caso concreto. A decisão judicial correta e justa será reflexo de uma análise dos elementos fáticos e, sobretudo, dos aspectos subjetivos envolvidos. É sabido que alguns magistrados se colocam contrários a esta modalidade de adoção e retiram crianças e adolescentes do convívio com prováveis adotantes, estejam eles habilitados ou não, recorrendo ao mandado de busca e apreensão. A criança é transferida para uma instituição de acolhimento ou, então, é entregue ao primeiro da fila que queira criança com aquele perfil. Este não é o tipo de conduta que procuramos aqui defender. Por que? Porque a maior prejudicada nesta briga, que reúne idas e vindas, medidas de busca e apreensão é exclusivamente a criança. Como pessoa em formação, não é justo o tratamento por vezes dispensado a ela. Criança não é coisa, não é bicho. É ser humano que reconhece pessoas como pais, pais que muitas vezes não são aqueles que o Juízo entende como aptos para tal.

\subsection{O Projeto de Lei $n^{\circ} 1212 / 2011$ : adoção consentida pode virar lei}

O Projeto de Lei $n^{\circ} 1212$ (ANEXO 6), de 03 de maio de 2011, de autoria do deputado Carlos Bezerra, do PMDB/MT, pretende acrescentar dispositivo ao Estatuto da Criança e do Adolescente, mais precisamente no artigo 50, objetivando a inserção do artigo 50-A, com a seguinte redação:

\footnotetext{
$\overline{82}$ BORDALLO, Galdino Augusto Coelho. Em Curso de direito da criança e do adolescente: aspectos teóricos e práticos. $4^{\mathrm{a}}$ ed.. Rio de Janeiro: Ed. Lumen Júris, 2010. p 252.
} 
Art. 50A. Serão adotados, independentemente da ordem no registro de criança e adolescentes em condições de serem adotadas ou no registro de pessoas interessadas na adoção, aqueles que, atendendo às demais condições legais, especialmente as previstas nos parágrafos do art. 28 , no art. 29 e no art. 43:

I - tenham sido expressamente doados pelo genitor ou genitores conhecidos;

II - tenham sido acolhidos, em situação de perigo devido a abandono, por pessoas que venham a se interessar pela adoção.

O referido projeto de lei visa que seja permitida a adoção de crianças e adolescentes que tenham sido expressamente doados pelo genitor a determinada pessoa ou por pessoa que os tenha acolhido em situação de perigo ou abandono, independente da ordem no registro para adoção.

Para a advogada Tânia da Silva Pereira, presidente da Comissão da Infância e Juventude do IBDFAM, a aprovação deste projeto vai impedir que muitas crianças e adolescentes fiquem esquecidas em instituições, acrescentando que,

a possibilidade de se entregar o filho para uma pessoa em quem se confia, representa a chance de uma vida melhor à criança que não se pretende acolher. Finalmente, entregar um filho em adoção também é um ato de amor ${ }^{83}$.

$\mathrm{O}$ referido projeto de lei encontra-se "aguardando Parecer na Comissão de Seguridade Social e Família $(C S S F)^{84}$ ", tendo sido designada em $1^{\circ}$ de julho de 2013 a deputada Carmen Zanotto (PPS-SC) como relatora. Em linhas gerais, os próximos passos, de acordo com o fluxo de tramitação de projeto de lei ordinária na Câmara dos Deputados, imagem abaixo $^{85}$, são a apreciação conclusiva na Comissão de Seguridade Social e Família (CSSF) e posterior análise em Plenário.

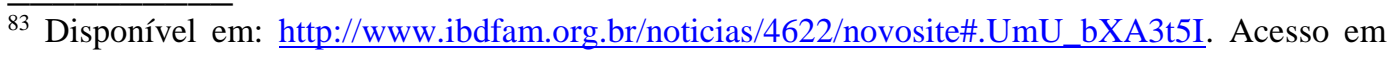
20/10/2013.

84 Disponível em: http://www.camara.gov.br/proposicoesWeb/fichadetramitacao?idProposicao=500199. Acesso em 20/10/2013.

85 Disponível em: http://www2.camara.leg.br/atividade-
legislativa/processolegislativo/fluxo/plTramitacao. Acesso em 20/10/2013.
} 
TRAMITAÇÃO DE UM PROJETO DE LEI ORDINÁRIA

NA CÂMARA DOS DEPUTADOS

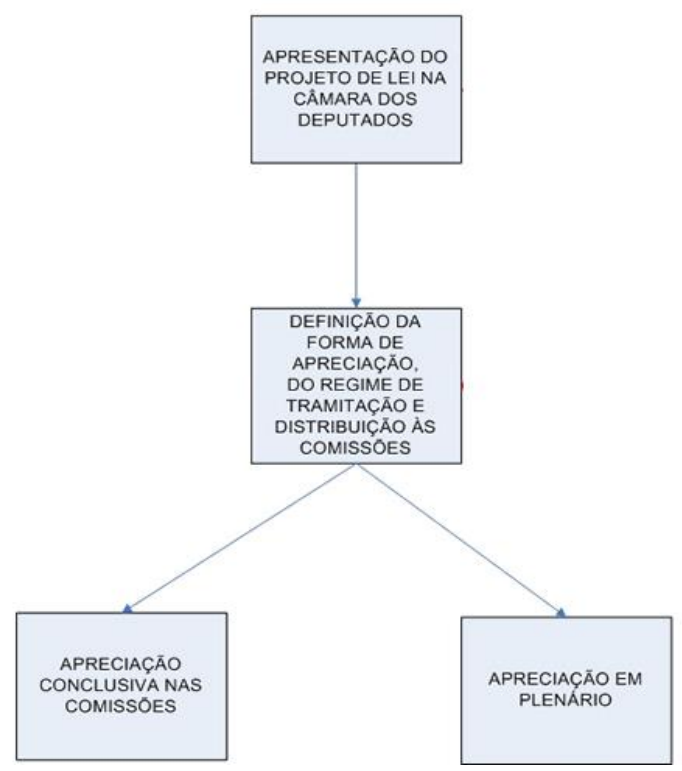




\section{CAPÍTULO 4. A adoção intuitu personae na jurisprudência}

Somente analisando as peculiaridades dos casos concretos é que, verdadeiramente, poderemos reconhecer a possibilidade da adoção intuitu personae realizada no melhor interesse do adotando, com o fim de inseri-lo no seio de uma família substituta. Segundo Tânia da Silva Pereira,

se a celeridade e a acessibilidade são desafios permanentes, superar a concepção elitizada e o excesso de burocracia com que são tratados os sentimentos humanos, também devem ser o compromisso do Sistema de Justiça informado pelo princípio constitucional da dignidade humana. (...) A adoção, na visão moderna, busca uma família para uma criança. A paternidade na adoção se constrói a cada dia, como função social, construída não só no sustento, guarda e educação, mas, sobretudo, no cuidado, elemento básico no exercício do Direito Fundamental à Convivência Familiar. ${ }^{86}$

Neste capítulo, analisaremos alguns julgados, dando ênfase aos seus aspectos mais relevantes e procurando destacar os aspectos neles presentes que dão ensejo à legalidade da adoção intuitu personae, assim como casos em que tal modalidade de adoção não pode ser admitida.

Primeiramente, passemos à análise do Recurso Especial 1172067.

\subsection{Recurso Especial 1172067/MG (ANEXO 6)}

Recorrentes: L. C. B e A. C. G. S. B, que ajuizaram ação de adoção com pedido de guarda provisória da infante L. C da C., filha de A. C. da C.

Interessado: A. C. da C., mãe biológica da infante, que tinha intenção de entregar a filha ao casal, ora recorrentes.

86 PEREIRA, Tânia da Silva. Direito da Criança e do Adolescente - uma proposta interdisciplinar. $2^{\mathrm{a}}$ ed.. São Paulo: Ed. Renovar, 2008. pp. 440-441. 
Inúmeros julgados citam como precedente o Recurso Especial 1172067/MG (ANEXO 6), que avalia se a regra de observância do cadastro de adoção deve prevalecer ou não no caso em análise, tendo como relator o Ministro MASSAMI UYEDA, da Terceira Turma, julgado em 18/03/2010, DJe 14/04/2010, com ementa in verbis:

RECURSO ESPECIAL - AFERIÇÃO DA PREVALÊNCIA ENTRE O CADASTRO DE ADOTANTES E A ADOÇÃO INTUITU PERSONAE APLICAÇÃO DO PRINCÍPIO DO MELHOR INTERESSE DO MENOR VEROSSÍMIL ESTABELECIMENTO DE VÍNCULO AFETIVO DA MENOR COM O CASAL DE ADOTANTES NÃO CADASTRADOS - PERMANÊNCIA DA CRIANÇA DURANTE OS PRIMEIROS OITO MESES DE VIDA TRÁFICO DE CRIANÇA - NÃO VERIFICAÇÃO - FATOS QUE, POR SI, NÃO DENOTAM A PRÁTICA DE ILÍCITO - RECURSO ESPECIAL PROVIDO. I - A observância do cadastro de adotantes, vale dizer, a preferência das pessoas cronologicamente cadastradas para adotar determinada criança não é absoluta. Excepciona-se tal regramento, em observância ao princípio do melhor interesse do menor, basilar e norteador de todo o sistema protecionista do menor, na hipótese de existir vínculo afetivo entre a criança e o pretendente à adoção, ainda que este não se encontre sequer cadastrado no referido registro; II - É incontroverso nos autos, de acordo com a moldura fática delineada pelas Instâncias ordinárias, que esta criança esteve sob a guarda dos ora recorrentes, de forma ininterrupta, durante os primeiros oito meses de vida, por conta de uma decisão judicial prolatada pelo i. desembargador-relator que, como visto, conferiu efeito suspensivo ao Agravo de Instrumento n. 1.0672.08.277590-5/001. Em se tratando de ações que objetivam a adoção de menores, nas quais há a primazia do interesse destes, os efeitos de uma decisão judicial possuem o potencial de consolidar uma situação jurídica, muitas vezes, incontornável, tal como o estabelecimento de vínculo afetivo; III - Em razão do convívio diário da menor com o casal, ora recorrente, durante seus primeiros oito meses de vida, propiciado por decisão judicial, ressalte-se, verifica-se, nos termos do estudo psicossocial, o estreitamento da relação de maternidade (até mesmo com o essencial aleitamento da criança) e de paternidade e o consequente vínculo de afetividade; IV - Mostrase insubsistente o fundamento adotado pelo Tribunal de origem no sentido de que a criança, por contar com menos de um ano de idade, e, considerando a formalidade do cadastro, poderia ser afastada deste casal adotante, pois não levou em consideração o único e imprescindível critério a ser observado, qual seja, a existência de vínculo de afetividade da infante com o casal adotante, que, como visto, insinua-se presente; $\mathrm{V}$ - O argumento de que a vida pregressa da mãe biológica, dependente química e com vida desregrada, tendo já concedido, anteriormente, outro filho à adoção, não pode conduzir, por si só, à conclusão de que houvera, na espécie, venda, tráfico da criança adotanda. Ademais, o verossímil estabelecimento do vínculo de afetividade da menor com os recorrentes deve sobrepor-se, no caso dos autos, aos fatos que, por si só, não consubstanciam o inaceitável tráfico de criança; VI - Recurso Especial provido.”

Da ementa supracitada, podemos extrair diversos ensinamentos, argumentos que, de fato, vem sendo utilizados por nossos julgadores de forma a considerar a legalidade da adoção intuitu personae, também 
chamada de dirigida ou consentida. São lições que demonstram a preocupação dos juízes com o melhor interesse da criança e do adolescente, o que implica desobedecer a "filla". Abre-se mão de "dar" a criança ou o adolescente àquele que foi habilitado, e por conseqüência inserido no cadastro de adotantes, em detrimento de uma situação fática já configurada por laços de afeto. Assim sendo, é de suma importância frisar que a questão da adoção dirigida precisa ser analisada no caso concreto, levando em conta as suas reais peculiaridades. Nesta linha, inúmeras demandas que chegam ao Judiciário procuram avaliar se a regra do cadastro de adotantes prevalece ou não sobre pretensões, pretensões estas que já envolvem a guarda, na maioria das vezes de fato ou informal, de menores, vínculos de afetividade. Sobre tais aspectos se debruça a análise do referido Recurso Especial, paradigma em relação ao tema.

\subsubsection{Análise do relatório}

Das palavras do Relator, Sr. Ministro Massami Uyeda,

os elementos dos autos dão conta de que os ora requerentes L. C. B. e A. C. G. S. B. ajuizaram ação de adoção da infante L. C. da C., filha de A. C. da C., com pedido liminar de guarda provisória (e-STJ - fls. 33/44). Para tanto, noticiaram que, antes mesmo do nascimento da menor, o qual se deu em 12 de dezembro de 2007, a mãe biológica da criança, durante a gestação, manifestara sua intenção de entregar a filha para a adoção, e, por um liame entre pessoas comuns às partes, direcionou tal manifestação ao casal, ora recorrentes". E mais: "compareceram em Juízo a mãe da menor, A. C. da C., e o casal, ora requerentes, onde assinaram o Termo de Declaração, no qual há expressa manifestação de vontade da primeira em consentir a adoção de sua filha por L. C. B. e A. C. G. S. B, sem coação ou benefício pessoal, razão pela qual o r. Juízo plantonista, em 28.12.2007, autorizou a permanência da menor, sob a guarda do casal, pelo prazo de trinta dias. Conclusos os autos ao r. Juízo de Direito da $1^{\text {a }}$ Vara Criminal e de Menores da Comarca de Sete Lagoas/MG, este determinou, em 25.1.2008, a imediata expedição de busca e apreensão da menor(...).

A medida de busca e apreensão foi assim decidida com a justificativa de que o artigo 50 do Estatuto traz a vontade do legislador de que $o$ casal devidamente inscrito e habilitado (observada a ordem cronológica de sua 
inscrição) teria, como tem, indiscutível prioridade na adoção de crianças ou adolescentes legalmente consideradas aptas para tanto. ${ }^{87}$

Ainda assim, os propósitos contidos no referido dispositivo, que preconiza a manutenção de um registro de pessoas interessadas na adoção (e recentemente prestigiado pelo $\mathrm{CNJ}$, com a edição, inclusive, da Resolução n. 54, já anteriormente analisada no capítulo 2, item 2.2) não podem ser vistos, de plano, como mandamento absoluto sob pena de se cometer um erro gravíssimo. Sabidamente, a medida de busca e apreensão não chegou a ser cumprida, vez que foi deferido efeito suspensivo ao recurso de agravo de instrumento:

sob o argumento de que o procedimento para adoção não se sobrepõe ao princípio do melhor interesse do menor, determinando a imediata entrega da menor aos recorrentes, com a realização de estudo psicossocial destes, e a oitiva do representante do Ministério Público.

Apesar do cuidado do legislador em estabelecer tais regras, encarar o cadastro como algo absoluto seria fechar os olhos para situações fáticas em que a regra do cadastro não foi observada, mas que o melhor interesse da criança e do adolescente está sendo respeitado. Esta hipótese excepcional é vivenciada pelos ora recorrentes.

$\mathrm{O}$ agravo de instrumento, que fora recebido com efeito suspensivo em 26/01/2008, foi julgado improvido em 29/07/2008, restabelecendo a decisão que determinou a busca e a apreensão da criança. $\mathrm{O}$ acórdão do agravo de instrumento teve parte de sua ementa assim redigida:

Havendo forte suspeita de que foi obtida guarda de fato de forma irregular e, até mesmo criminosa, impõe-se o indeferimento da guarda provisória com a 'incontinenti' busca e apreensão da criança que ainda não conta com sequer um ano de idade. 3. Agravo de instrumento conhecido e não provido, mantida a decisão interlocutória que indeferiu a guarda provisória e determinou a busca e a apreensão da criança.

Em $1^{\circ}$ de agosto de 2008, portanto, após aproximadamente 8 meses ininterruptos da guarda da criança pelos ora recorrentes (28.12.2008), cumpriu-se a ordem de busca e apreensão. Interposto recurso especial, este

\footnotetext{
$\overline{87 \text { ANEXO 6, p. } 4}$
} 
restou inadmitido pelo Tribunal de origem, ensejando a contraposição de agravo de instrumento, o qual, por decisão da Relatoria, restou provido, convertendo-o no presente recurso especial. Por meio da Medida Cautelar n.15.097/MG, tanto ao agravo de instrumento, bem como ao presente recurso especial, foi atribuído efeito suspensivo.

Sobre o mérito do Recurso Especial aqui em análise sustentam os recorrentes que "a lista de adotantes não pode se sobrepor ao prioritário interesse da criança, que conviveu com os recorrentes durante seus primeiros oito meses de vida", " que o estudo psicossocial demonstrou a capacidade e a aptidão do casal para adotar a menor (...).", "que a adoção intuitu personae não se revela espúria, restando demonstrado nos autos a forma lícita e legítima pela qual se deu a indicação do casal pela mãe biológica", e, por fim, ainda afirmam que "o referido laudo psicossocial restou completamente ignorado pelas Instâncias ordinárias".

\subsubsection{Análise do voto do Relator:}

O Relator inicia seu voto afirmando que a tese defendida pelos recorrentes merece prosperar. $\mathrm{O}$ ponto central de discussão repousa na análise da prevalência ou não da regra de observância do cadastro, constante no artigo 50 do ECA, sobre a situação vivida pelos recorrentes, já que estes desejam adotar criança que esteve sob a guarda deles, por ocasião de decisão judicial, desde seu nascimento até os seus primeiros oitos meses de vida. Discute-se, também, nas palavras do Relator, se "se a adoção intuitu personae, na qual os pais biológicos da criança escolhem a família que a adotará, consubstancia, no caso dos autos, forma espúria de $\operatorname{adoção(\ldots ..~})^{88 "}$.

Sobre o cadastro de adoção, Uyeda destaca seus aspectos positivos, deixando clara a necessidade de se avaliar os casos concretos, o que flexibiliza a obrigatoriedade de observá-lo:

\footnotetext{
$\overline{{ }^{88} \text { ANEXO 6, p.7. }}$
} 
[...] Sem dúvida, a existência de cadastro de adotantes tende a observar o melhor interesse do menor, além de encerrar inúmeras vantagens ao procedimento legal da adoção, na medida em que avalia previamente os pretensos adotantes por uma comissão técnica multidisciplinar, minimiza a possibilidade de eventual tráfico de crianças ou mesmo a adoção por intermédio de influências escusas, bem como propicia igualdade de condições àqueles que pretendem adotar. É certo, contudo, que a observância de tal cadastro, vale dizer, a preferência das pessoas cronologicamente cadastradas para adotar determinada criança, não é absoluta. E nem poderia ser. Excepciona-se tal regramento, em observância ao princípio do melhor interesse do menor, basilar e norteador de todo o sistema protecionista do menor, na hipótese de existir vínculo afetivo entre a criança e o pretendente à adoção, ainda que este não se encontre sequer cadastrado no referido registro $[\ldots]^{89}$.

Diante disso, a aferição da formação de vínculo afetivo entre a criança e os recorrentes já basta para que se considere a possibilidade da adoção intuitu personae, adoção consentida pela mãe biológica da criança. Quanto a isso não se pode ter dúvidas: "é incontroverso nos autos, de acordo com a moldura fática delineada pelas Instâncias ordinárias, que esta criança esteve sob a guarda dos ora recorrentes, de forma ininterrupta, durante os primeiros oito meses de vida, (...) tem o condão de estabelecer o vínculo de afetividade da menor com os pais adotivos.(...) Bem de ver, assim, mostrar-se insubsistente o fundamento adotado pelo Tribunal de origem no sentido de que a criança, por contar com menos de um ano de idade, e, considerando a formalidade do cadastro, poderia ser afastada deste casal adotante, pois não levou em consideração o único e imprescindivel critério a ser observado, qual seja, a existência de vínculo de afetividade da infante com o casal adotante, que, como visto, insinua-se presente. 90" Tal perspectiva se encaixa à excepcionalidade de inobservância do cadastro na hipótese do $\$ 13$ do artigo 50 do Estatuto, não se prendendo à literalidade das situações dispostas nos incisos, mas aceitando certa flexibilização, por exemplo, na idade da criança e no parentesco dela com os adotantes, de forma que seja levada fundamentalmente em consideração a existência de vínculos de afeto.

\footnotetext{
${ }^{89}$ ANEXO 6.

${ }^{90}$ ANEXO 6, p. 8.
} 


\subsection{Recurso Especial $\mathbf{n}^{\circ}$ 1.262.996 - RN (ANEXO 7)}

_Recorrente : Ministério Público do Estado do Rio Grande do Norte

_Recorrido : J. B. A. B. e outro, autores na ação de adoção da criança T. M. da S., que foi julgada improcedente.

Interessados. : M. G. B. e T.M. da S.

_Precedentes citados: REsp 1172067/MG, julgado em 18/03/2010; e REsp 837324/RS, julgado em 31/10/2007)

Passamos à análise do Recurso Especial n 1.262.996 - RN de relatoria do Ministro Sidnei Beneti, publicado em 22/06/2012, no qual o Ministério Público alega violação dos artigos 50 - "A autoridade judiciária manterá, em cada comarca ou foro regional, um registro de crianças e adolescentes em condições de serem adotados e outro de pessoas interessadas na adoção"- e 197-E - "Deferida a habilitação, o postulante será inscrito nos cadastros referidos no art. 50 desta Lei, sendo a sua convocação para a adoção feita de acordo com ordem cronológica de habilitação e conforme a disponibilidade de crianças ou adolescentes adotáveis", ambos do Estatuto da Criança e do Adolescente.

Trata-se de ação original de adoção de incapaz pelos ora recorridos. Tal demanda foi julgada improcedente com o fundamento de inobservância da ordem de preferência constante no cadastro nacional de adoção (artigo 50 do ECA). Inconformados, os recorridos apelaram e obtiveram êxito com a tese de que o melhor interesse do incapaz deveria prevalecer no caso em exame. O Acórdão da Apelação foi assim ementado:

CIVIL E PROCESSO CIVIL. DIREITO DA CRIANÇA E DO ADOLESCENTE.APELAÇÃO CÍVEL. AÇÃO DE ADOÇÃ̂O. CASAL INSCRITO NO CADASTRO NACIONALDE ADOÇÃO, INSTITUÍDO PELA LEI 12.010/09. ADOÇÃO INTUITU PESSONAE (CONSENTIDA) FORA DA ORDEM CRONOLÓGICA PREVISTA NO ART. 197-E DA NOVA LEI. ADMISSIBILIDADE. REGRA GERAL QUE DEVE SER FLEXIBILIZADA DE ACORDO COM AS PECULIARIDADES DO CASO CONCRETO. PREVALÊNCIA DOS INTERESSES DA CRIANÇA, SOB A GUARDA DOS ADOTANTES DESDE O NASCIMENTO, HÁ APROXIMADAMENTE 1 (UM) ANO. VÍNCULO DE AFETIVIDADE 
CONSTITUÍDO ENTRE OS PRETENDENTES À ADOÇÃO E O MENOR. PEDIDO JURIDICAMENTE POSSÍVEL, CONFORME JURISPRUDÊNCIA PACÍFICA DO STJ E TRIBUNAIS ESTADUAIS PÁTRIOS, INCLUSIVE DESTA CORTE. APLICABILIDADE DO DISPOSTO NOS ARTIGOS 227 DA CF/88 E 43 DO ECA. SENTENÇA ANULADA. RECURSO CONHECIDO E PROVIDO.

Com o Recurso Especial em comento pretendeu o Recorrente, Ministério Público, atacar a decisão proferida. O Relator, de saída, relembrou que o assunto é tema já pacificado pela jurisprudência do STJ, o que dá ensejo ao julgamento monocrático, sendo a adoção dirigida plenamente legal quando feita no melhor interesse da criança ou do adolescente. É indubitável a situação fática de afeto estabelecida, o que justifica afastar o mandamento contido no artigo 50 do Estatuto. Os argumentos trazidos no Relatório são incisivos neste sentido:

A celeuma instaurada no presente recurso especial não é nova nesta Corte. Centra-se em saber se, em processo de adoção, a observância do cadastro de adotantes prevalece ou não sobre a pretensão dos ora recorrentes de adotar criança que esteve sob a guarda destes - a partir de seu nascimento e os seus primeiros meses de vida. Veja-se, inicialmente, não se olvidar os nobres propósitos contidos no artigo 50 do Estatuto da Criança e do Adolescente, que preconiza a manutenção, em comarca ou foro regional, de um registro de pessoas interessadas na adocãa, e legitimamente incentivado, recentemente, pelo Conselho Nacional de Justiça, com a edição, inclusive, da Resolucãa n. 54. Sem dúvida, a existência de cadastro de adotantes tende a observar o melhor interesse do menor, além de encerrar inúmeras vantagens ao procedimento legal da adoção, na medida em que avalia previamente os pretensos adotantes por uma comissão técnica multidisciplinar, minimiza a possibilidade de eventual tráfico de crianças ou mesmo a adoção por intermédio de influências escusas, bem como propicia igualdade de condições àqueles que pretendem adotar. É certo, contudo, que a observância de tal cadastro, vale dizer, a preferência das pessoas cronologicamente cadastradas para adotar determinada criança, não é absoluta. E nem poderia ser. Excepciona-se tal regramento, em observância ao princípio do melhor interesse do menor, basilar e norteador de todo o sistema protecionista do menor, na hipótese de existir vínculo afetivo entre a criança e o pretendente à adoção, ainda que este não se encontre sequer cadastrado no referido registro. (...) Observe-se, ainda, que além da aferição da imprescindível capacidade e aptidão do casal pretendente à adocão em exercer efetivamente o Poder Familiar, sendo relevante para tanto, indubitavelmente, 0 parecer psicossocial em conjunto com toda a instrucão processual, o que se dará durante o processo de adocão, in casu, preponderantemente, deve-se perscrutar o estabelecimento por parte da menor de vínculo afetivo com os ora recorrentes, que, como visto, poderá tornar legítima, indubitavelmente, a adocão intuitu personae. Resta patente, que no caso dos autos, tem-se que a guarda de uma crianca, sem 
interrupcões, durante os seus primeiros dias de vida, tem o condão de estabelecer o vínculo de afetividade da menor com os pais adotivos ${ }^{91}$

\subsection{Agravo em Recurso Especial no 256.238 - RN (ANEXO 8)}

_Agravante: Ministério Público do Estado do Rio Grande do Norte por ofensa aos arts. 46, 50, caput, § $5^{\circ} \mathrm{e} 197-\mathrm{E}$ do Estado da Criança e do Adolescente.

_Agravado: M. A. L. de A. e outros

Interessado: F. P. de O.

_Precedentes citados: Recurso Especial 889852-RS; e Recurso Especial 837324-RS.

A adoção intuitu personae foi novamente enfrentada quando do julgamento do Agravo em Recurso Especial $n^{\circ} 256.238$ - $\mathrm{RN}$ (2012/0240145-0), interposto diante da decisão que não admitiu o Recurso Especial, tendo como Relator o Ministro Marco Buzzi, publicado em 01/02/2013. Novamente a análise repousa sobre a controvérsia em saber se a inscrição no Cadastro Nacional de Adoção (CNA) é requisito imprescindível à adoção da criança/adolescente.

O Tribunal a quo, ao analisar a controvérsia, reformou a sentença de primeiro grau, que extinguiu o feito sem julgamento do mérito, por impossibilidade jurídica do pedido, ante a ausência de registro dos adotantes no Cadastro Nacional de Adoção. A Corte de origem considerou as peculiaridades do caso concreto, a fim de determinar o regular prosseguimento do feito no juízo de primeiro grau, quais sejam: o exercício da guarda da criança pelos adotantes desde o nascimento desta; o intenso vínculo afetivo estabelecido entre o menor e os pretensos pais; a ausência de indícios de tráfico de pessoas ou motivos escusos; e o princípio do melhor interesse da criança. Enfrentando o ARESP em questão, o Ministro Marco Buzzi assim escreveu:

\footnotetext{
$\overline{{ }^{91} \text { ANEXO 7,pp. }}$ 2-5.
} 
Compulsando os autos, verifica-se que os requerentes, ora apelantes, ao postularem a adoção da criança apresentaram a declaração da mãe biológica da criança, na qual afirma que a criança nascida em 10/02/2010, encontra-se com os mesmos desde o dia 12/02/2010, (fl. 08), ocasião em que a criança contava apenas com dois dias de idade. No entanto, deixaram de comprovar a inscrição no Cadastro Nacional de Adoção, nos termo do artigo 50 do Estatuto da Criança e do Adolescente. Ocorre que, tal exigência pode ser relativizada em prol do melhor interesse da crianca, de modo a permitir a aplicacão de medida que melhor favoreca ao bem estar do menor. Com efeito, o referido Cadastro confere lisura ao procedimento legal da adoção, buscando elidir eventual tráfico de crianças ou mesmo a adoção por intermédio de influências escusas, além de propiciar igualdade de condições àqueles que pretendem adotar. In $\operatorname{casu}_{2} \mathbf{a}$ crianca se encontra sob os cuidados dos apelantes desde 12/02/2010, portanto há mais de dois anos, revelando o estabelecimento de vínculo afetivo, o qual deve ser considerado na análise do pleito autoral, sob pena de se aplicar medida jurídica lesiva aos interesses do menor. Ademais, não há indícios de tráfico ou motivos escusos a ensejar a pretensa adoção. Sempre na busca de priorizar a proteção do infante, a jurisprudência é uníssona no entendimento de ser possível a adocão "intuitu personae", na qual os pais biológicos escolhem a família que adotará a criança, quando já houver laços afetivos entre esta e os pretensos adotantes, senão vejamos: [...] Portanto, retirar, nesse momento, a criança do convívio da família com quem se encontra há quase 2 anos, e que lhe dispensa os cuidados necessário ao seu desenvolvimento, a princípio, implica em afronta à seu melhor interessse. Mister ponderar que, considerando que não foi realizado qualquer exame psicossocial, resta insubsistente o argumento de que a criança, por contar com menos de um ano de idade, poderia ser afastada dos recorrentes por não existir o vínculo de afetividade entre o infante e o pretenso casal adotante, o que, "prima facie", revela-se presente. Dessa forma, não deve prevalecer o indeferimento da petição inicial na ação de adoção em razão do casal requerente não se encontrar habilitado no Cadastro de Adoção, sob pena de sobrepor a forma ao melhor direito da criança.[...] 3. Correto o posicionamento encampado pela Corte originária. Não obstante a importância do Cadastro Nacional de Adoção, que coloca a bom termo os diversos interesses que pairam sobre a perfilhação, em casos excepcionalíssimos, é possível que a adoção se dê sem a observância do referido rol, tendo em vista o princípio do melhor interesse do menor. Destarte, não se afigura juridicamente impossível o pedido de adoção em relação ao menor não cadastrado no Registro Nacional de Adoção feito por aqueles que exercem a guarda de fato há mais de 2 (dois) anos, ainda que não inscritos na referida lista, já que tal exigência pode ser afastada, em casos excepcionais, como o presente, em que se vislumbra laços de afetividade entre o casal adotante e a criança, conforme delineia o aresto Estadual.[... $]^{92}$

Para corroborar a sua tese, tese esta amplamente apoiada na tendência seguida pelo STJ, o ministro Buzzi citou outros precedentes. Fazse oportuna a transcrição das ementas de alguns acórdãos. O primeiro deles, RESP 889852/RS, verifica a existência de reais vantagens aos adotandos à medida que há laços de afeto consolidados. Já o segundo acórdão, do

\footnotetext{
$\overline{92}$ ANEXO 8, pp. $2-3$.
} 
julgamento do RESP $837324 / \mathrm{RS}$, demonstra que a regra do respeito ao cadastro não pode ser absoluta quando já há vínculos de afeto entre a criança e/ou adolescente e seus pais efetivos, motivo pelo qual ela não deverá ser retirada de onde já estabeleceu vínculos e onde encontra-se integrada. Abaixo, seguem as ementas referidas:

\section{Precedente citado: Recurso Especial 889852-RS (ANEXO 9)}

DIREITO CIVIL. FAMÍLIA. ADOÇÃO DE MENORES POR CASAL HOMOSSEXUAL. SITUAÇÃO JÁ CONSOLIDADA. ESTABILIDADE DA FAMÍLIA. PRESENÇA DE FORTES VÍNCULOS AFETIVOS ENTRE OS MENORES E A REQUERENTE. IMPRESCINDIBILIDADE DA PREVALENNCIA DOS INTERESSES DOS MENORES. RELATÓRIO DA ASSISTENTE SOCIAL FAVORÁVEL AO PEDIDO. REAIS VANTAGENS PARA OS ADOTANDOS. ARTIGOS $1^{\circ}$ DA LEI 12.010/09 E 43 DO ESTATUTO DA CRIANÇA E DO ADOLESCENTE. DEFERIMENTO DA MEDIDA. 1. A questão diz respeito à possibilidade de adoção de crianças por parte de requerente que vive em união homoafetiva com companheira que antes já adotara os mesmos filhos, circunstância a particularizar o caso em julgamento. [...] Por qualquer ângulo que se analise a questão, seja em relação à situação fática consolidada, seja no tocante à expressa previsão legal de primazia à proteção integral das crianças, chega-se à conclusão de que, no caso dos autos, há mais do que reais vantagens para os adotandos, conforme preceitua o artigo 43 do ECA. Na verdade, ocorrerá verdadeiro prejuízo aos menores caso não deferida a medida. 15. Recurso especial improvido. (REsp 889852/RS, Rel. Ministro LUIS FELIPE SALOMÃO, QUARTA TURMA, julgado em 27/04/2010, DJe $10 / 08 / 2010)$

\section{Precedente citado: Recurso Especial 837324-RS (ANEXO 10)}

CIVIL. FAMÍLIA. GUARDA PROVISÓRIA. COMÉRCIO DE MENOR. INEXISTENTE. FAMÍLIA AFETIVA. INTERESSE SUPERIOR DO MENOR. OBSERVÂNCIA DA LISTA DE ADOÇÃO. - Mesmo em havendo aparente quebra na lista de adoção, é desaconselhável remover criança que se encontra, desde os primeiros dias de vida e por mais de dois anos, sob a guarda de pais afetivos. A autoridade da lista cede, em tal circunstância, ao superior interesse da criança (ECA, Art. 6º ). (REsp 837324/RS, Rel. Ministro HUMBERTO GOMES DE BARROS, TERCEIRA TURMA, julgado em 18/10/2007, DJ 31/10/2007, p. 325).

\subsection{Outros julgados}

Nossos Tribunais de Justiça têm seguido a mesma linha dos acórdãos até aqui analisados, demonstrando que os cadastros estaduais e o nacional de adotantes e adotados não podem ser regra absoluta, sob pena de se 
esvaziar todo um rol de interesses que visa à proteção da criança e do adolescente e sua consequente colocação em família substituta. Muito mais do que privilegiar nossos dispositivos legais, faz-se necessário sempre levar em conta as peculiaridades do caso concreto, no estabelecimento de vínculos de afeto, peculiaridades estas que conduzirão nossos julgadores em suas tomadas de decisões.

\subsubsection{TJRJ - Apelação $n^{\circ} 0006371-74.2009 .8 .19 .0061^{93}$}

A apelação $\mathrm{n}^{\circ}$ 0006371-74.2009.8.19.006194, julgada em 05/05/2010, teve como relator o desembargador Nagib Slaibi. O recurso foi conhecido e não provido por unanimidade. A ação originária tramitou no interior do Rio de Janeiro. A mãe e a avó materna desconheciam o estado gravídico da primeira, o que somente foi descoberto na ocasião do parto. O pai era desconhecido. Neste contexto, a genitora decidiu entregar a filha para a adoção. A autora da ação de adoção, já inserida no cadastro, teve convivência estabelecida com a recém-nascida desde o seu quinto dia de vida, tendo a família biológica concordado com a adoção após conhecê-la. Constam nos autos laudos da assistente social afirmando que a criança está bem cuidada e adaptada em lar harmonioso. O acórdão da apelação dispôs acerca da legalidade da adoção intuitu personae ao esclarecer que

o critério a ser observado é a existência de vínculo de afetividade da criança com o casal adotante. Dever-se-ia, preponderantemente, verificar o estabelecimento do vínculo afetivo da criança com os agravados, que, se presente, torna legítima, indubitavelmente, a adoção intuito personae.

E foi assim ementado:

ADOÇÃO DIRIGIDA OU INTUITU PERSONAE. CADASTRO DE ADOÇÃO. REQUERENTES HABILITADOS. ORDEM CRONOLÓGICA. INOBSERVÂNCIA. INEXISTÊNCIA DE ILEGALIDADE.

\footnotetext{
${ }^{93}$ Acórdão com resolução de mérito em segredo de justiça. Disponível em: http://www4.tjrj.jus.br/ejud/ConsultaProcesso.aspx?N=201000113305. Acesso em 17/10/2013.

${ }^{94}$ Disponível em:

http://www.emerj.tjrj.jus.br/serieaperfeicoamentodemagistrados/paginas/series/11/normatividadeju ridica 51.pdf. Acesso em 14/10/2013.
} 
Dessa forma, não resta dúvida de que não há ilegalidade em não se observar a ordem cronológica do cadastro, já que os vínculos estabelecidos entre a mãe adotiva escolhida pela genitora e o infante configuram a situação excepcional segundo a qual não se observará a referida ordem.

\title{
4.4.2. TJRJ - Agravo de Instrumento $\mathrm{n}^{\circ}$ 0026403-89.2009.8.19.000095
}

A ementa a seguir transcrita deixa clara a possibilidade de escolha dos pais adotivos pela genitora, de forma a que prevaleça o melhor interesse do menor. Assim, temos:

\begin{abstract}
ADOÇÃO DIRIGIDA OU INTUITU PERSONAE. GUARDA PROVISÓRIA DE MENOR. CADASTRO DE ADOÇÃO. REQUERENTES HABILITADOS. ORDEM CRONOLÓGICA. IRRELEVÂNCIA. ADOÇÃO DIRETA. PEDIDO DE GUARDA PROVISÓRIA INDEFERIDO, DETERMINANDO BUSCA E APREENSÃO DO MENOR E ENCAMINHAMENTO A ABRIGO, COM FUNDAMENTO NO ARTIGO 50 DA LEI No 8.069/1990. Inobstante a regra legal de ordem cronológica de inscrição, tem-se que o alcance da lei, no sentido de garantir isenção e impessoalidade na adoção, não afasta a possibilidade de a mãe biológica, por seus próprios motivos, escolher a quem entregar o filho para adoção. Agravantes que já eram habilitados para adoção, quando surgiu o desejo da mãe biológica em entregar-lhes o filho para ser adotado, o que foi concretizado em manifestação de vontade. Posse de fato exercida desde o nascimento e durante pouco mais de um mês suficiente para o estabelecimento de vínculo afetivo e reconhecimento de situação consolidada, devendo prevalecer o princípio do melhor interesse da criança. Deferimento do pedido de guarda provisória até decisão final na Ação de Adoção. Provimento do recurso.
\end{abstract}

\subsubsection{TJRS - Apelação Cível $n^{\circ} 70015551138$ (ANEXO 11)}

A apelação em comento teve a seguinte ementa:

CÍVEL. ESTATUTO DA CRIANÇA E DO ADOLESCENTE. ADOÇÃO INTUITU PERSONAE. ADMISSÃO, NO CASO CONCRETO, ANTE A EXCEPCIONALIDADE DA SITUAÇÃO FÁTICA. Tendo a mãe da menor entregue a sua filha em adoção a um casal, não é de se desconsiderar tal vontade apenas em razão da existência de uma listagem de casais habilitados para adoção, uma vez que a lista serve para organizar a ordem de preferência na adoção de crianças e adolescentes, e segue a ordem de antigüidade, não podendo, ao fim e ao cabo, ter maior importância que o ato da adoção em si. Outrossim, os apelantes são pessoas já habilitadas para adoção e encontram-se na lista. Ademais, uma vez verificado o sólido estabelecimento de laços afetivos entre as partes envolvidas na

\footnotetext{
95 Acórdão com resolução do mérito em segredo de justiça. Disponível em:
} http://www4.tjrj.jus.br/ejud/ConsultaProcesso.aspx?N=200900220364. Acesso em 14/10/2013. 
relação familiar, e tendo em conta que o Estatuto da Criança e do Adolescente estrutura-se de maneira a que sempre se priorize a melhor situação para o menor, a procedência do recurso se impõe.

Trata-se de recurso contra a sentença que, nos autos do requerimento de adoção, julgou improcedente a demanda, determinando a busca e apreensão da criança. A ementa supracitada esclarece que, apesar da existência da ordem de preferência do Cadastro de Adoção, esta não pode ter maior importância do que os interesses do adotando.

O Relator Ricardo Raupp Rauschel menciona que, sempre que demandas deste tipo chegam à Corte, ressurge o seguinte dilema:

retirar a criança de uma família solidamente constituída, para fazê-la retornar à família biológica, que a "rejeitou" ou, em alguns casos, a um abrigo, até que se decida com quem definitivamente ficará? Ou manter a criança com a já mencionada família, solidamente constituída e candidata à adoção, ainda que em desacordo com a legislação em vigor? Ao que tudo indica, há apenas uma certeza em relação a tal dilema, qual seja, a de que não se pode "fechar" a questão, ou seja, estabelecer uma regra genérica aplicável a todos os casos análogos. Ao contrário, cada caso há que ser considerado isoladamente e, suas peculiaridades, consideradas essenciais a um deslinde adequado que, sempre, privilegie a melhor situação para o menor ${ }^{96}$.

Neste caso, a mãe biológica, desde a gestação, quis entregar a filha aos apelantes, e sempre teve ciência das conseqüências que poderiam advir de tal circunstância. Deste modo, o recurso de apelação foi provido, sendo homologada a manifestação de vontade da genitora, revogando a decisão que determinou a busca e apreensão da criança e possibilitando o prosseguimento do feito à integral regularização da adoção pleiteada. Importante voltar a ressaltar que há situações excepcionais onde a guarda de fato enseja a criação de um vínculo consolidado, autorizando a adoção intuito personae.

\subsubsection{TJSP - Apelação Cível n 116.199-0/8-00 (ANEXO 12)}

A apelação tem como objetivo atacar a sentença que julgou extinto o processo sem julgamento do mérito, indeferindo a petição inicial de pedido

\footnotetext{
${ }^{96}$ ANEXO 11, pp. 4-5.
} 
de guarda. Ficou evidenciado nos autos que a intenção dos ora apelantes não era pedido de guarda, mas de adoção intuitu personae. Sobre o tema, esclarece o Relator Sidney Romano, "admissível se mostra a adoção intuitu personae, mas somente quando existente vínculo de parentesco ou amizade profunda, o que não ocorre na espécie ${ }^{977 " . ~ A s s i m ~ s e n d o, ~ " n a d a ~ r e c o m e n d a, ~}$ nestes autos, solução diversa da que foi tomada na $r$. sentença, devendo ser vedada prática como a pretendida, não somente para se evitar burla ao cadastro de adotantes, mais especialmente no sentido de conferir à criança a maior proteção possível".

No caso em análise, portanto, não há situação excepcional que justifique a não observância do cadastro de adotantes, motivo pelo qual a pretensão autoral não prosperou, em nome da doutrina da proteção integral da criança e do adolescente. A apelação foi assim ementada:

APELAÇÃO CÍVEL - GUARDA DEMENOR -
IMPROCENDENCIA - SENTENÇA DE
INADMISSIBILIDADE - INTERESSE QM ADOÇÃO INTUITU PERSONAE
POR CASAL QUE NÃO TEM PARENTESCO COM A MÃE BIOLÓGICA E
QUE A CONHECEU POUCOS DIAS DEPIS DO NASCIMENTO DA
CRIANÇA - DECLARAÇÃO DE QUE PRETENDIAM ADOTAR O
INFANTE - TENTATIVA DE BURLA AO CADASTRO DE ADOTANTES -
SENTENÇA MANTIDA - APELAÇÃO IMPROVIDA.

Do exame neste capítulo realizado acerca das decisões judiciais, concluímos que se faz necessário o crucial cuidado por parte dos nossos julgadores no sentido de perceberem as circunstâncias verdadeiras e legítimas que dão brecha ao deferimento de pedidos de adoção dirigida. Por conseguinte, devem estes sempre ter em mente que a adoção é medida excepcional; que é alternativa quando esgotados os meios de manutenção da criança e do adolescente na família natural ou extensa, consoante o disposto no parágrafo $1^{\circ}$ do artigo 39 do Estatuto. E o estabelecimento do vínculo de afeto, interpretado em consonância com o melhor interesse do adotando, precisa nortear a tomada de decisão dos nossos Magistrados no

\footnotetext{
$\overline{{ }^{97} \text { ANEXO } 12, \text { p. }} 3$.
} 
entendimento inteligente e razoável sobre a legalidade da adoção intuitu personae. Como bem aponta Tânia da Silva Pereira,

se a celeridade e a acessibilidade são desafios permanentes, superar a concepção elitizada e o excesso de burocracia com que são tratados os sentimentos humanos, também deve ser o compromisso do Sistema de Justiça informado pelo princípio constitucional da dignidade da pessoa humana. ${ }^{98}$

${ }_{98}$ PEREIRA, Tania da Silva. Direito da Criança e do Adolescente, uma proposta interdisciplinar. $2^{a}$ ed.. Editora Renovar, 2008. pp. 440-441. 


\section{CONCLUSÃO}

Tendo em vista os aspectos observados ao longo deste trabalho, entendemos que a adoção intuitu personae é plenamente legal e possível quando realizada no melhor interesse do adotando. Embora seja um tipo de adoção combatida no Brasil por não existir previsão legal expressa autorizando-a, recebe pouco tratamento na doutrina. E é justamente a ausência de um dispositivo legal que autorize expressamente tal modalidade de adoção que incrementa o debate. Em função disso, foi necessário proceder à análise de decisões judiciais, compreendendo o desafio do Poder Judiciário em perceber que, em consonância com o princípio constitucional da dignidade da pessoa humana, a paternidade/maternidade na adoção se constrói no dia a dia, no estabelecimento de vínculos socioafetivos que dão ensejo ao reconhecimento da legalidade da adoção intuitu personae.

Assim compreendemos pela legalidade porque o Estatuto da Criança e do Adolescente (ECA), que regula a adoção, com as alterações incluídas pela Lei 12.010/2009, não vedou literalmente tal modalidade. Nem mesmo a Constituição Federal de 1988 o fez. E mais: o mesmo ECA foi expresso ao permitir que se abrisse mão de respeitar o mandamento contido no caput do seu artigo 50, o de respeito à fila do cadastro, em detrimento da formação de vínculos de afinidade e afetividade, hipótese em que se defende a possibilidade da adoção intuitu personae. Assim sendo, o afeto surge como justificativa ao deferimento de pedidos que envolvam este tipo de adoção. E todas as decisões judiciais neste sentido acabam por priorizar os interesses do adotando, sendo a melhor solução a de permanência na sua família afetiva, mesmo que esta não seja a indicada pelo cadastro de adotantes.

Nesta linha, não faz sentido que se retire a acriança ou o adolescente do convívio com quem estabeleceu sentimento, afeto, ou seja, que o Judiciário recorra aos mandados de busca e apreensão, "coisificando" esses 
seres humanos que são constitucionalmente reconhecidos como titulares de direitos fundamentais e como pessoas em peculiar estágio de desenvolvimento. Respeitar e aplicar o cadastro é prática cogente, mas fechar os olhos para situações fáticas que justificam sua inobservância seria contrariar todo um sistema que foi criado para o fim maior de colocação da criança ou do adolescente em família substituta.

Fundamental, então, que se reconheça o afeto como valor jurídico. A leitura que se faz sobre a criança e o adolescente precisa ser a leitura destes enquanto sujeitos de desejos. A escolha dos pais afetivos feita pelos pais biológicos ou por aqueles que detenham o poder familiar é plenamente legítima quando decorre do afeto. E em função do peso dado pelo nosso ordenamento ao afeto é admitida a adoção intuitu personae realizada no melhor interesse da criança e do adolescente, sob pena de se frustrar os seus direitos fundamentais, tão fortemente preconizados em nosso ordenamento. 


\section{REFERÊNCIAS BIBLIOGRÁFICAS}

ALMEIDA, Julio Alfredo de. Adoção Intutitu Personae - uma proposta de agir. Síntese da Monografia de Especialização em Direito Comunitário: Infância e Juventude. Fundaçao Escola Superior do Ministério Público. Porto Alegre. 2002.

BECKER, Maria Josefina. Estatuto da Criança $e$ do Adolescente Comentado. $3^{\mathrm{a}}$ ed. São Paulo: Malheiros Editores Ltda, 2000.

BEVILACQUA, Clóvis. Código Civil dos Estados Unidos do Brasil Comentado. Vol. II, Livraria Francisco Alves, 1943.

BOEIRA, José Bernardo Ramos. Investigação de paternidade: posse de estado de filho: paternidade socioafetiva. Porto Alegre: Livraria do Advogado, 1999.

BORDALLO, Augusto Galdino Coelho. "Adoção”, In: Curso de Direito da Criança e do Adolescente: aspectos teóricos e práticos. $4^{\mathrm{a}}$ Ed.. São Paulo: Lumen Juris, 2010.

CHAVES, Antonio. Adoção e Legitimação adotiva. Ed. Rev. Dos Tribunais. 1966.

DIAS, Maria Berenice. Adoção e a espera do amor. Disponível em: http://www.mariaberenice.com.br/uploads/1 _ado\%E7\%E3o_e_a_espera_do_amor.pdf . Acesso em 15/10/2013.

DIAS, Maria Berenice. Manual de Direito das Famílias. $7^{\mathrm{a}}$ ed.. São Paulo: Ed. Revista dos Tribunais, 2011.

DIGIÁCOMO, Murillo José. Da impossibilidade jurídica da adoção intuitu personae no ordenamento jurídico brasileiro à luz da lei $n^{o}$. 12.010/2009e 
da Constituição Federal de 1988. Fonte: Disponível em: http://www.crianca.mppr.mp.br/modules/conteudo/conteudo.php?conteudo $=1081$. Acesso em 21/08/2013.

DINIZ, João Seabra. A adoção - Notas para uma visão global. In Abandono e Adoção - Contribuições para uma cultura da adoção. I.

DINIZ, Maria Helena. Curso de Direito Civil Brasileiro. Direito de Família. Vol. 5. Ed. Saraiva, 1995.

DUPRET, Cristiane. Direito da Criança e do Adolescente. Disponível em: http://canalconselhotutelar.files.wordpress.com/2012/01/329 apostila de e ca.pdf. Acesso em 18/10/2013.

FARIAS, Cristiano Chaves de; ROSENVALD, Nelson. Direito da Famílias, 2a . Ed. Rio de Janeiro: Lumen Juris, 2010.

FONSECA, Antonio Cesar Lima da. Direitos da criança e do adolescente. $2^{a}$ edição. São Paulo: Editora Atlas, 2012.

GAMA, Guilherme Calmon Nogueira da. Princípios Constitucionais de Direito de Família. São Paulo: Editora Atlas, 2008.

GOMES, Júlio César. Adoção intuitu personae e o princípio do melhor interesse do menor. Disponível em: http://www.juristas.com.br/informacao/artigos/adocao-intuitu-personae-e-oprincipio-do-melhor-interesse-do-menor/882/. Acesso em 18/10/2013.

GRANATO, Eunice Ferreira Rodrigues. Adoção, doutrina e prática com abordagem do novo Código Civil. $4^{\mathrm{a}}$ reimpressão. Curitiba: Juruá Editora, 2009.

GRANATO, Eunice. Adoção doutrina e prática. Ed. Juruá, 2009.

LISBOA, Sandra Maria. Adoção no Estatuto da Criança e do adolescente, doutrina e jurisprudência. Rio de Janeiro: Editora Forense, 1996. 
MACIEL, Kátia R. F. L. A. Em Curso de direito da criança e do adolescente: aspectos teóricos e práticos. $4^{\mathrm{a}}$ ed.. Rio de Janeiro: Editora Lumen Júris, 2010.

MADALENO, Rolf. Curso de Direito de Família. 2a ed.. Rio de Janeiro: Forense, 2008.

Manual de Adoção da AMB. Disponível em: http://www.amb.com.br/mudeumdestino/docs/Manual\%20de\%20adocao.pd f. Acesso em 03/10/2013.

Manual de procedimentos para adoção do CONSIJ. Disponível em: http://www.mprs.mp.br/infancia/legislacao/id2193.htm. Acesso em 28/09/13.

MOREIRA, Silvana do Monte. A adoção intuitu personae e a necessária habilitação prévia. Disponível em: http://silvanammadv.blogspot.com.br/2012/02/adocao-intuitu-personae-enecessaria.html. Acesso em 18/10/2013.

OLIVEIRA, J. M. Leoni Lopes de. Guarda, Tutela e Adoção. $3^{\mathrm{a}}$ ed.. Rio de Janeiro: Editora Lumen Juris, 2000.

PEREIRA, Caio Mário da Silva. Instituições de Direito Civil. Volume V. Direito de Família. 17 ${ }^{\mathrm{a}}$ ed.. Rio de Janeiro: Editora Forense, 2009.

PEREIRA, Sergio Gischkow. A adoção e o direito intertemporal. In: Revista dos Tribunais, v.686.

PEREIRA, Tânia da Silva. Direito da Criança e do Adolescente - uma proposta interdisciplinar. $2^{\mathrm{a}}$ ed.. São Paulo: Renovar, 2008.

PERLINGIERI, Pietro. O direito civil na legalidade constitucional. Rio de Janeiro: Renovar, 2008.

PERLINGIERI, Pietro. Perfis do direito civil - introdução ao direito civil constitucional. 3. ed. São Paulo: Renovar, 2007. 
PONTES DE MIRANDA. Tratado de Direito Privado. v.9. Ed. Borsoi. 1951.

RODRIGUES, Direceu A. Victor. Dicionário de Brocardos Jurídicos. São Paulo: Ed. Ateniense, 1995.

ROSSATO, Luciano Alves; LÉPORE, Paulo Eduardo. Comentários à Lei Nacional de Adoção - Lei 12.010, de 03 de agosto de 2009. São Paulo: Revista dos Tribunais, 2009.

SOUZA, Rodrigo F. de. Juiz de Direito da $2^{\mathrm{a}}$ Vara de Família, Infância, Juventude e Idoso da Comarca de Nilópolis - RJ - Revista da EMERJ, v. $12, n^{\circ} 45,2009$.

TAVARES, José de Farias. Comentários ao Estatuto da Criança e do Adolescente. 7. ed.. Rio de Janeiro: Gen-Forense, 2010.

VALLADÃO, Luiz Fernando. Paternidade socioafetiva. Disponível em: http://www.ibdfam.org.br/artigos/811/Paternidade+socioafetiva. Acesso em 09/10/2013. 


\section{SITES}

http://www.cnj.jus.br/atos-administrativos/atos-da-

presidencia/resolucoespresidencia/12216-resolucao-no-93-de-27-de-

outubro-de-2009. Acesso em 17/09/2013.

http://www.ambito-

juridico.com.br/site/index.php?n_link=revista_artigos_leitura\&artigo_id=9 498. Acesso em 16/10/2013.

http://www.cnj.jus.br/images/programas/cadastro-adocao/guia-usuarioadocao.pdf - página 10. Acesso em 03/10/2013.

http://www.cnj.jus.br/noticias/cnj/22951-aumenta-numero-de-adotantesindiferentes-a-raca-de-criancas. Acesso em 07/10/2013.

http://www.mprs.mp.br/infancia/legislacao/id2193.htm. Acesso em 28/09/2013.

http://www.juristas.com.br/informacao/artigos/adocao-intuitu-personae-e-oprincipio-do-melhor-interesse-do-menor/882/. Acesso em 18/10/2013.

http://www.amb.com.br/mudeumdestino/docs/Manual\%20de\%20adocao.pd f. Acesso em 03/10/2013.

http://www.ibdfam.org.br/artigos/811/Paternidade+socioafetiva. Acesso em 09/10/2013. 
http://www.tjrs.jus.br/site/poder_judiciario/tribunal_de_justica/corregedoria _geral_da_justica/acoes/encontros_de_execucao_penal/encontros_de_juizes _da_infancia_e_juventude/conclusoes_1encontro_infancia.html. Acesso em 20/10/2013.

http://stj.jusbrasil.com.br/jurisprudencia/14318607/recurso-especial-resp1000356-sp-2007-0252697-5/inteiro-teor-14318608. Acesso em $15 / 10 / 2013$

http://canalconselhotutelar.files.wordpress.com/2012/01/329 apostila_de_e ca.pdf. Acesso em 18/10/2013.

http://www.arrudaeadvogados.adv.br/downloads/adocaointuitopersonae.pdf . Acesso em 20/10/2013.

http://www.stj.jus.br/SCON/infojur/doc.jsp?livre=@ $\operatorname{cod}=0385$. Acesso em $15 / 10 / 2013$

http://www.mariaberenice.com.br/uploads/1_ado\%E7\%E3o e a espera do amor.pdf Acesso em 15/10/2013.

http://www.ibdfam.org.br/noticias/4622/novosite\#.UmU_bXA3t5I. Acesso em 20/10/2013.

http://www.camara.gov.br/proposicoesWeb/fichadetramitacao?idProposica $\mathrm{o}=500199$. Acesso em 20/10/2013.

http://www2.camara.leg.br/atividadelegislativa/processolegislativo/fluxo/plTramitacao. Acesso em 20/10/2013. 
http://www4.tjrj.jus.br/ejud/ConsultaProcesso.aspx?N=201000113305. Acesso em 17/10/2013.

http://www.emerj.tjrj.jus.br/serieaperfeicoamentodemagistrados/paginas/ser ies/11/normatividadejuridica 51.pdf . Acesso em 14/10/2013.

http://www4.tjrj.jus.br/ejud/ConsultaProcesso.aspx?N=200900220364. Acesso em 14/10/2013.

http://www.ibdfam.org.br/artigos/920/Quem+\%C3\%A9+Duda\%3F. Acesso em 31/10/2013.

http://www.paginadocidadao.com.br/cartilha/cartilha-do-cadastro-nacionalde-adocao-manual-do-usuario. Acesso em 09/11/2013.

http://www.amb.com.br/mudeumdestino/?secao=cartilhas. Acesso em $09 / 11 / 2013$. 


\section{ANEXOS}

Anexo 1: Lei 12.010, de 03 de agosto de 2009 (LEI DE ADOÇÃO). Disponível em: http://www.planalto.gov.br/ccivil_03/_ato20072010/2009/lei/112010.htm.

Anexo 2: Portaria 214 do CNJ, de 29 de fevereiro de 2008http://www.cnj.jus.br/atos-administrativos/atos-dapresidencia/portarias-presidencia/22773-portaria-n-214-de-14-dedezembro-de-2012.

Anexo 3: Resolução 54 do $\mathrm{CNJ}$, de 29 de abril de 2008 http://www.cnj.jus.br/atos-administrativos/atos-dapresidencia/resolucoespresidencia/12169-resolu-no-54-de-29-de-abril-de$\underline{2008 .}$.

Anexo 4: Resolução 93 do CNJ. Disponível em: http://www.cnj.jus.br/atosadministrativos/atos-da-presidencia/resolucoespresidencia/12216resolucao-no-93-de-27-de-outubro-de-2009.

Anexo 5: Projeto de lei $\mathrm{n}^{\circ}$ 1212/2011http://www.camara.gov.br/proposicoesWeb/prop_mostrarintegra;jsessionid $=$ E97A669737B5859EA8A89B9EA1CA7FAF.node1?codteor=865458\&fil ename $=P L+1212 / 2011$.

Anexo 6: Recurso Especial 1172067/MG.

Anexo 7: Recurso Especial n 1.262.996 - RN.

Anexo 8: Agravo em Recurso Especial no 256.238 - RN.

Anexo 9: Recurso Especial 889852-RS.

Anexo 10: Recurso Especial 837324-RS.

Anexo 11: Apelação Cível nº 70015551138.

Anexo 12: Apelação Cível n 116.199-0/8-00. 